\title{
Behavioral Ecology of the Swainson's Hawk (Buteo Swainsoni) in Washington
}

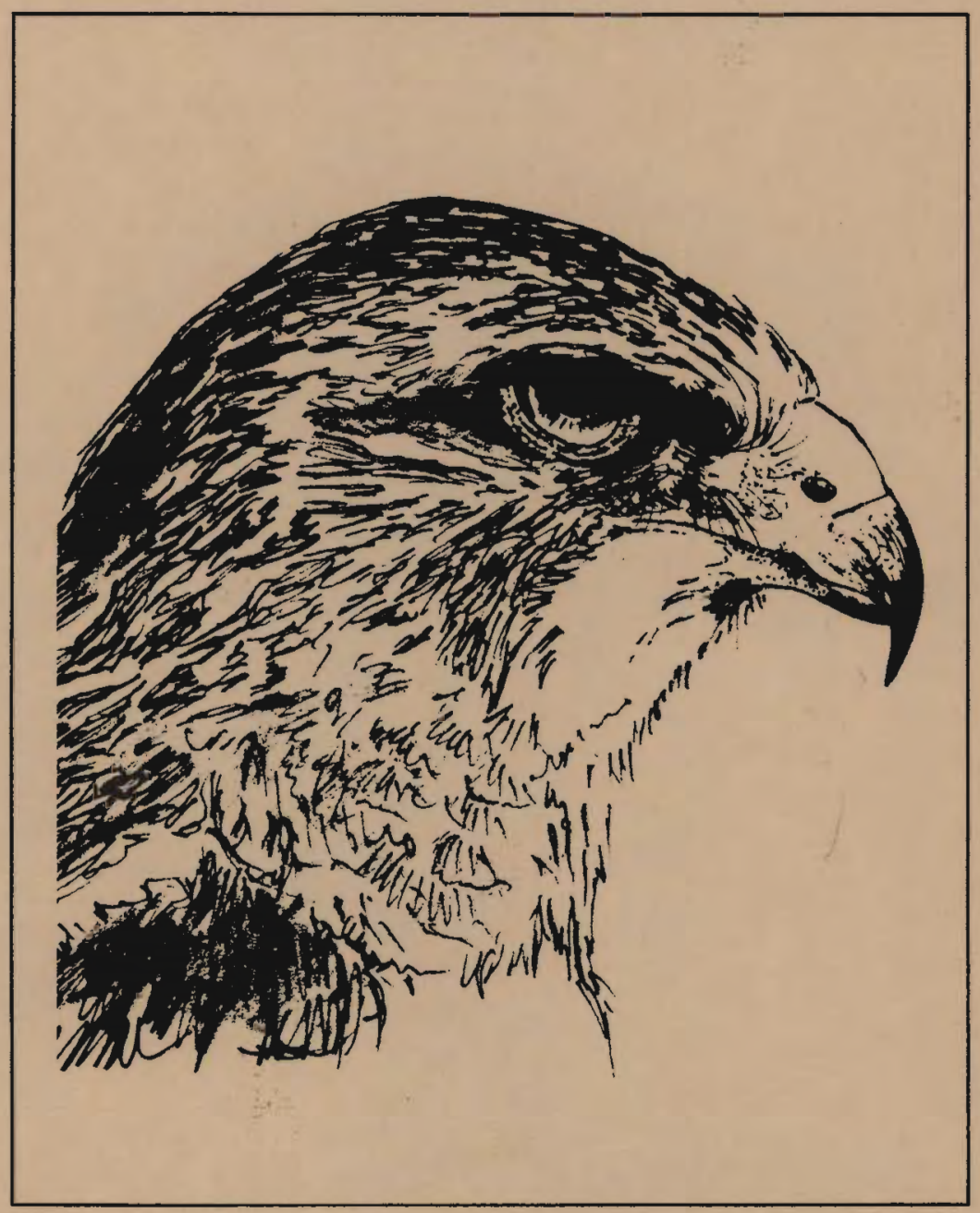

Prepared for the

Department of Energy under

Contract DE-AC06-76RLO 1830

Pacific Northwest Laboratory Operated for the U.S. Department of Energy by Battelle Memorial Institute 


\title{
NOTICE
}

This report was prepared as an account of work sponsored by the United States Government. Veither the United States nor the Department of Energy, nor any of their employees, nor any of their contractors, subcontractors, or their employees, makes any warranty, express or implied, or assumes any legal liability or responsibility for the accuracy. completeness or uselulness of any information. apparatus, product or process disclosed. or represents that its use would not infringe privately owned rights.

The views, opinions and conclusions contained in this report are those of the contractor and do not necessarily represent those of the United States Government or the United States Department of Energy.

\author{
PACIFIC NORTHWEST LABORATORY \\ operated by \\ BATTELLE \\ for the \\ UNITED STATES DEPARTMENT OF ENERGY \\ Under Contract DE-AC06-76RLO 1830
}
Printed in the United States of America
Available rrom
Vational Technical Information Service
United States Department of Commerce
5285 Port Royal Road
Springfield. Virginia 22151

Price: Printed Copy \$

$\because$ Microtiche $\$ 3.00$

VTIS

* Pages Selling Price

$\begin{array}{ll}001-025 & \$ 4.00 \\ 026-050 & \$ 4.50 \\ 051-075 & \$ 5.25 \\ 076-100 & \$ 6.00 \\ 107-125 & \$ 6.50 \\ 126-150 & \$ 7.25 \\ 157-175 & \$ 8.00 \\ 176-200 & \$ 9.00 \\ 201-225 & \$ 9.25 \\ 226-250 & \$ 9.30 \\ 251-275 & \$ 10.75 \\ 276-300 & \$ 11.00\end{array}$




\title{
33679000491904
}

BEHAVIORAL ECOLOGY OF THE SWAINSON'S HAWK (Buteo swainsoni) IN WASHINGTON

\author{
R. E. Fitzner
}

December 1980

Prepared for

the U.S. Department of Energy

under Contract DE-AC06-76RLO 1830

Pacific Northwest Laboratory Richland, Washington 99352 


\section{SUMMARY}

This study examines the breeding ecology and behavior of the Swainson's Hawk (Buteo swainsoni) on its breeding ground in southeastern Washington. Seasonal movements and distribution of the buteo are also described.

The study lasted from April 1973 until October 1977. Primary study areas were the United States Department of Energy's Hanford Site, the juniper area of Franklin County and the Pullman-Colfax vicinity of Whitman County. Limited data were also collected in four other areas during the summer of 1975. The birds were observed from blinds, or filmed by Super-8mm time-1apse cameras, during courtship, nest building, egg laying, incubation, and nestling and post-fledging development.

During courtship, the male was observed to perform acrobatic aerial displays to a flying or perching female. Copulation usually took place in the morning, after the male was solicited vocally and positionally by the female, and lasted for an average of 7.2 seconds.

The Swainson's Hawks built nests primarily in trees, usually selecting Black Locusts and Chinese Elms. Nests were built at an average height of $4.6 \mathrm{~m}$ above ground, and measured $738.5 \mathrm{~mm}$ (mean) in diameter. Grasslands and cultivated lands were the main nesting habitats.

Generally, Swainson's Hawks laid one to four eggs, with two being the most common clutch size. The mean number of days from laying to hatching was 34.5. Young fledged after an average of 42.9 days. Beyond the fifth day after fledging, young seldom returned to the nest. Fledgling flight behavior was observed and described. Young remained dependent on aduits for most of their food until migration.

Home range sizes, derived from marked and radiotagged hawks, averaqed $9.08 \mathrm{~km}^{2}$ for males and $3.44 \mathrm{~km}^{2}$ for females. Five marked adults returned in the spring of 1977 to nest sites used the previous year, indicating that Swainson's Hawks may use the same nest site year after year.

Food habits were examined during the nestling and post-fledging periods. Snakes, especially the abundant Western Yellow-bellied racers, were a prey staple, and insects became an important food source during the post-fledging period. It was apparent that Swainson's Hawks feed on smaller and more diverse prey than sympatric buteos (Red-tailed and Ferruginous Hawks), thus reducing competition with neighboring congenerics. Interactions with buteos and other raptor genera were observed, and nearest neighbor distances measured.

Organochlorine pesticides in prey species consumed by Swainson's !lawks are concentrated from prey to predator through the food chain. The hawk pellets (regurgitated castings) would contain those concentrations and could easily be monitored without sacrificing any part of the food chain. 


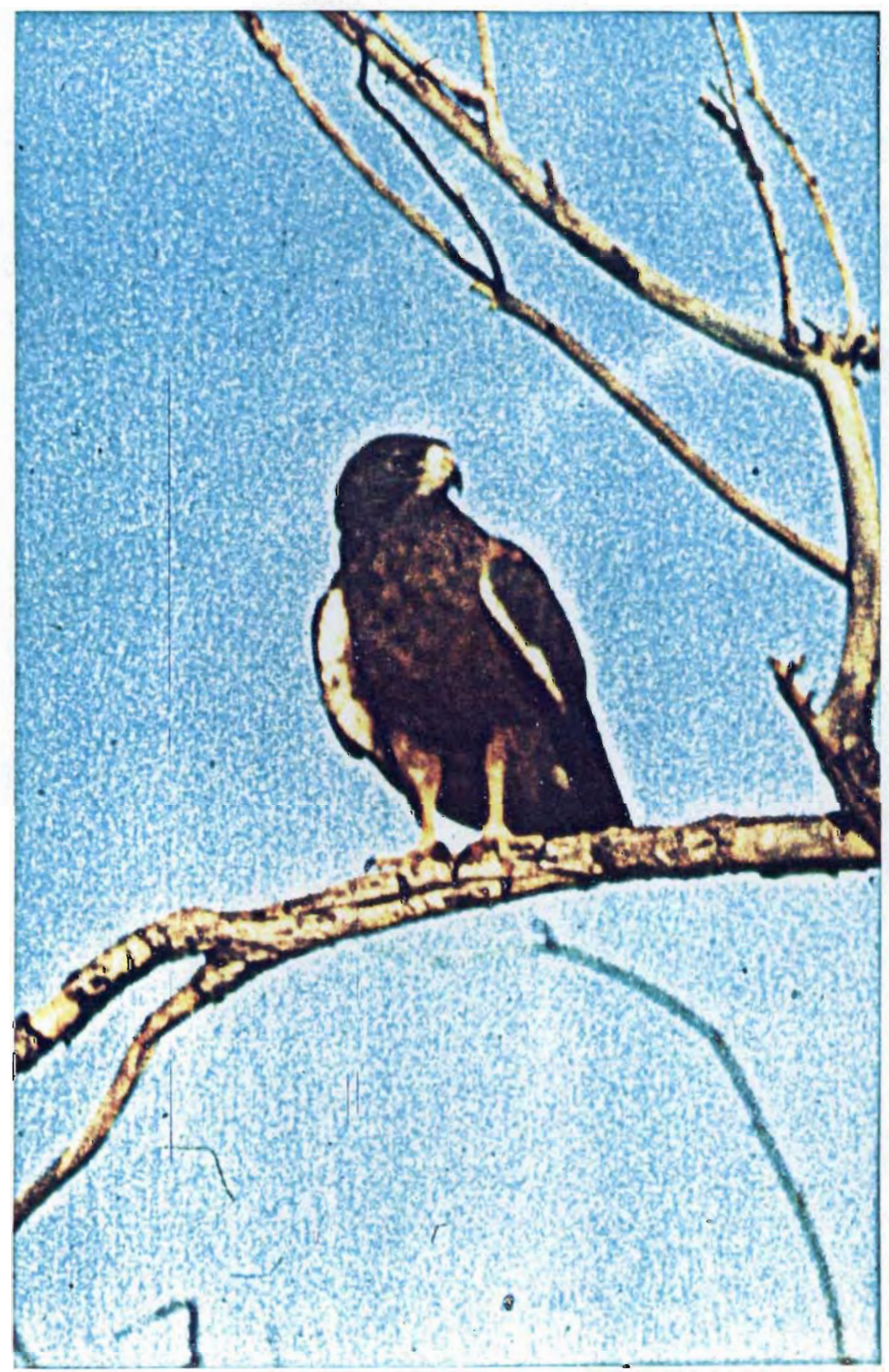




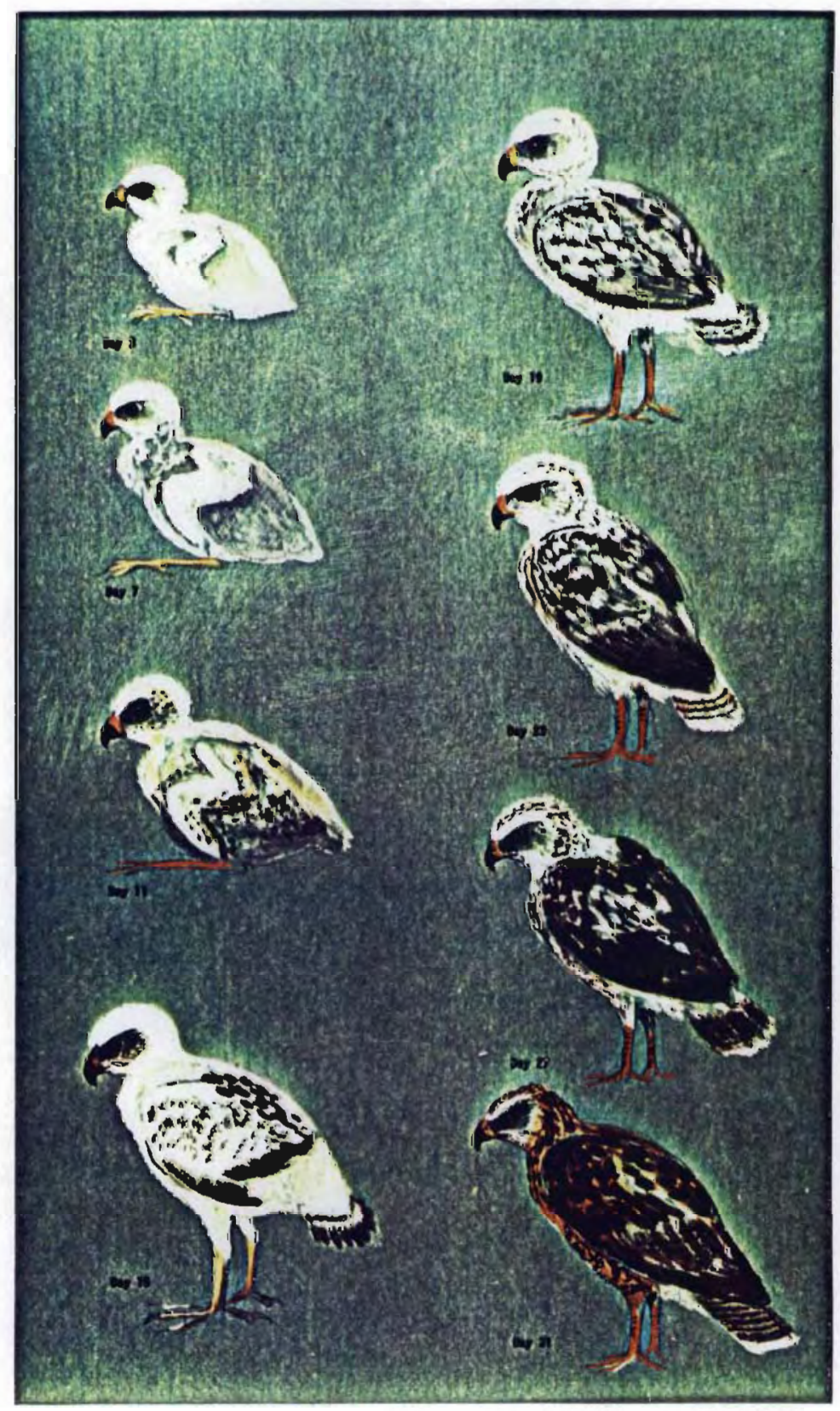

PLATE II 

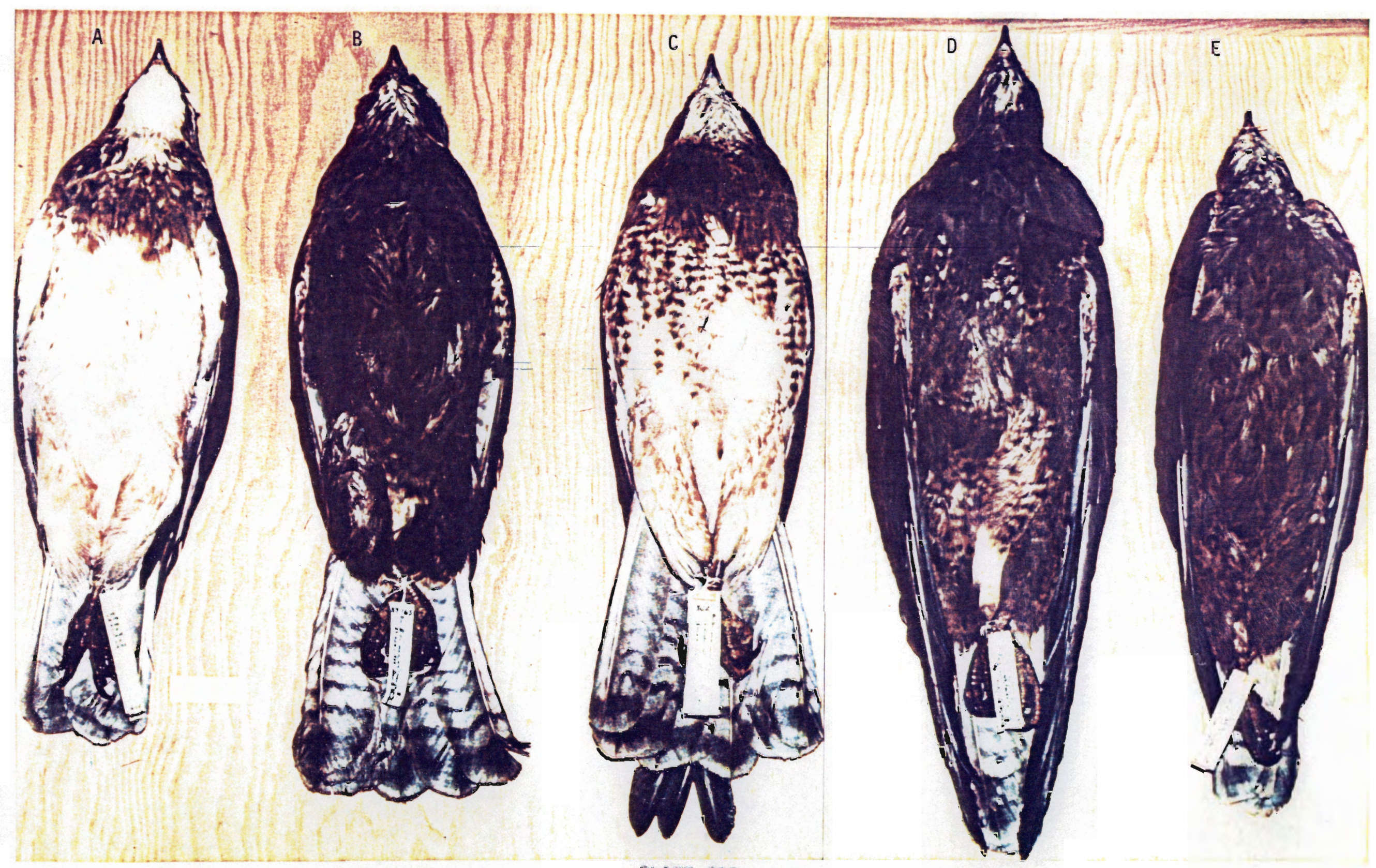

PLATE III 

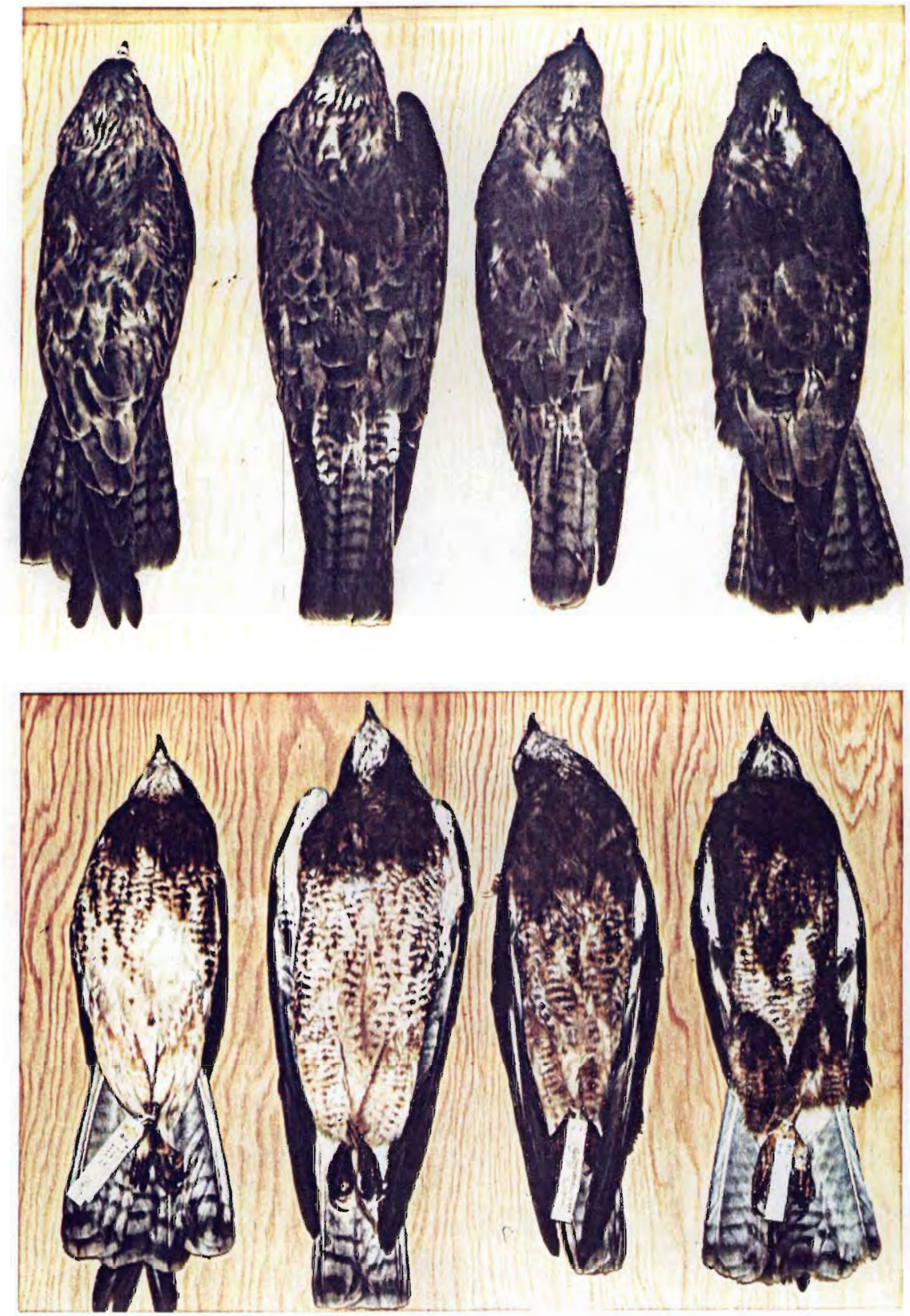


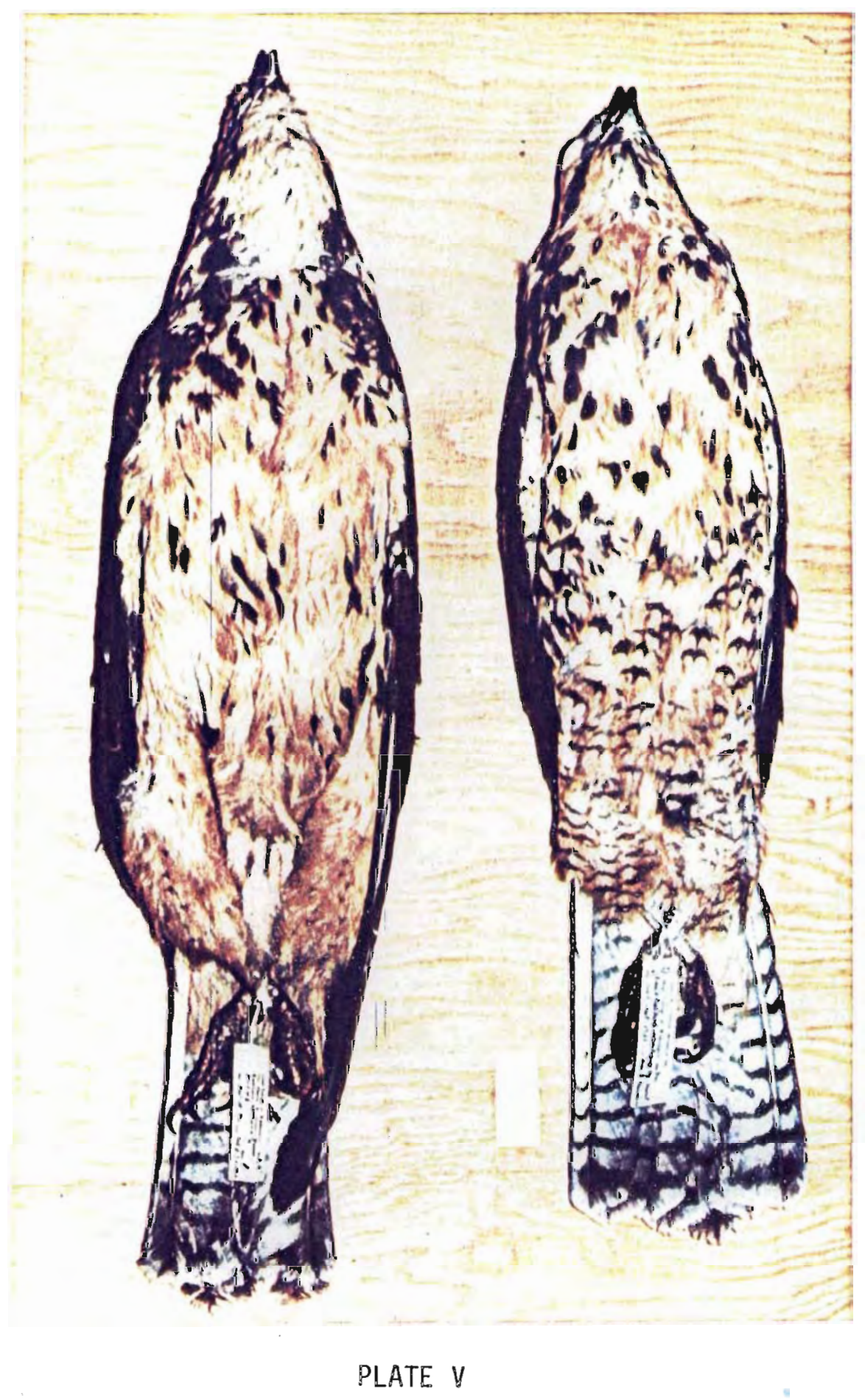




\section{$\underline{\text { PLATES }}$}

I The Adult Swainson's Hawk

II Growth of the young Swainson's Hawk in 4 day intervals

III Color phases of adult Swainson's Hawks. (A) Light phase, (B) Melanistic phase, (C) Intermediate phase, (D) Erythristic phase (dark rust), (E) Erythristic phase

IV Intermediate plumage variations in Swainson's Hawks. (A) and (B) Intermediate light phases, (C) and (D) Intermediate dark phases

$V$ First year Plummage of the Swainson's Hawk 
INTRODUCTION

METHODS

GENERAL PROCEDURES

CAPTURE AND ANALYTIC TECHNIQUES

Trapping

Time-Lapse Film Analys is

STUDY AREAS

GENERAL DEŚCRIPTION

INTENSIVE STUDY AREAS

Hanford Site

Juniper Area

Pullman/Colfax Area

MORPHOLOGY OF THE SWAINSON'S HAWK

ADULTS

EGGS

YOUNG

COLOR PHASES

ADULT PLUMAGES

JUVENILE PLUMAGES

DISTRIBUTION IN NORTH AND SOUTH AMERICA

BREEDING RANGE

WINTERING RANGE

MIGRATION

DISTRIBUTION IN WASHINGTON

Breeding Distribution

NESTING CHRONOLOGY

COURTSHIP

COPULATION

NESTING

NEST SITE SELECTION AND CHARACTERISTIICS NEST CONSTRUCTION

EGG LAYING

CLUTCH INITIATION AND RATE OF EGG-LAYING CLUTCH SIZE

INCUBATION STAGE ADULT BEHAVIOR DURATION OF INCUBATION

NESTLING PERIOD

ADULT BEHAVIOR

Attent iveness

Brooding

Shading

Feeding

NESTLING DEVELOPMENT AND BEHAVIOR Duration of Nestling Period Deve lopment Fratricide and $\dot{C}$ annibalism

POST-FLEDGLING PERIOD POST-FLEDGLING BEHAVIOR

Day 1 through 4

Day 5 through 8

Day 9 through 12

Day 13 through 16

Day 17 through 20

Day 21 through 25

Day 26 through 29

Day 30 through 33

Day 34 through 39 


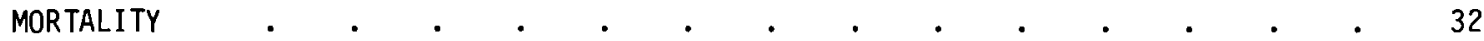

DAILY MOVEMENTS OF FLEDGL INGS AND SIZE OF POST-FLEDGING AREA $\dot{F}^{\circ} \quad \cdot \quad \cdot \quad \cdot \quad \cdot \quad 32$

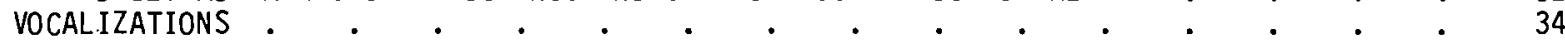

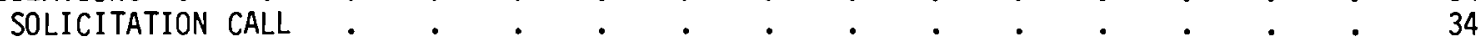

AGONISTIC PURSUIT CALL $\cdot$ •

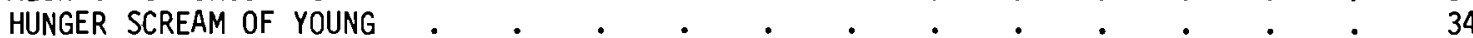

TERRI TORIALITY

HOME RANGE AREA

NEST FAITHFULNESS

USE OF HOME RANGES BY THREE ADULTS

PRODUCTIVITY AND POPULATION LEVELS

NESTING PARAMETERS

PRODUCTIVITY OF THE SWAINSON'S HAWK IN SOUTHEASTERN WASHINGTON Productivity

CLUTCH SIZE

HATCHING SIZE

FLEDGING SUCCESS

PRODUCTIVITY OF SWAINSON'S HAWKS IN NORTH AMERICA

Clutch Size

Maximum Brood Size

Fledging Success

FOOD HABITS

Nesting Success

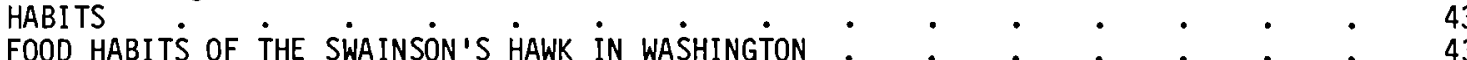

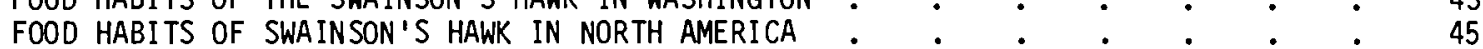
HUNTING TACTICS

INTRA- AND INTERSPECIFIC RELATIONSHIPS:

INTERSPECIFIC RELATIONSHIPS

Interactions Between Raptor Species

MANAGEMENT

Interactions with Non raptors.

MANAGEMENT RECOMMENDATIONS

Field Evidence for the Potential for Management

FIELD TECHNIQUE CONSIDERATIONS FOR THE MANAGEMENT OF SWAINSON'S HAWK Tree Planting Man-Made Nest Sites

ENVIRONMENTAL POLLUTANTS

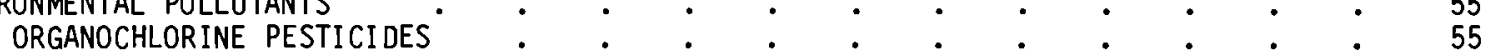

REFERENCES 
1. Measurements (mm) and Weights (g) of Adult Swainson's Hawks on

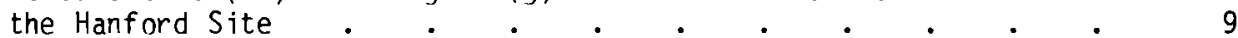

2 Egg Length, Width and Weight in the Swainson's Hawk . . . 10

3 Study Skins of Swainson's Hawks Contained in Washington Museums . 18

4 Nest Sites Used by Swainson's Hawks in Southeastern Washington . 19

5 Number and Fate of Nests Associated with Dominant Habitat Types Observed in Southeastern Washington . . . . . 23

6 Materials Observed Being Carried to Two Nests Under

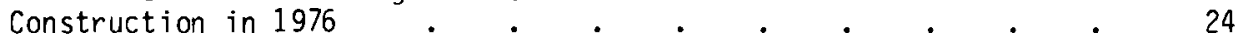

7 Egg Deposition Rate in Swainson's Hawks on the Hanford Site . 25

8 Chronology of Egg Development in the Swainson's Hawk - 1977 • 26

9 Nestling Period of Swainson's Hawk Young in Southeastern

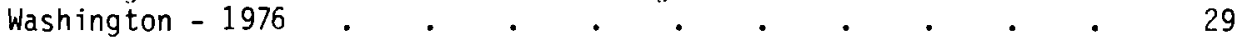

10 Post-Fledging Period of Swainson's Hawks in Southeastern Washington - 1976 . $. \quad . \quad . \quad . \quad . \quad . \quad$. $\quad$. 30

11 Home Range Sizes of Adult Swainson's Hawks on the

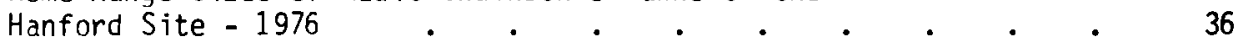

12 Nesting history of the Swainson's Hawk on the Hanford Site . . 38

13 Productivity of Swainson's Hawk on the Hanford Site . . . 38

14 Clutch Size in all Nests where Complete Clutches Were Counted on the Hanford Site $. \quad . \quad . \quad . \quad . \quad . \quad . \quad . \quad 39$

15 Data from Nest Sites in Which Young Fledged, where Prior Details Were Known on the Hanford Site . . . . . . 39

16 Clutch Size, Maximum Brood Size and Fledging Success of the Swainson's Hawk in North Amnerica . • • • • . 39

17 Breeding Data Summary for Swainson's Hawks on the Hanford Site -

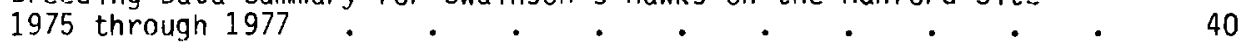

18 Productivity of Swainson's Hawks in Southeastern 40

19 Productivity of Young Swainson's Hawks per Known Adult Pair . . 42

20 Nest Successes of Swainson's Hawks in the United States . . 42

21 Prey Fed to Nestling Swainson's Hawks as Determined from Super-8mm Time-Lapse Photography . . . . . . . . 43

22 Prey Fed to Young Swainson's Hawks by Parent Birds on the Hanford Site - 1973-76 
23 Prey Fed to Young Swainson's Hawks in Whitman County, Washington near Pullman $\quad . \quad \cdot \quad \cdot \quad \cdot \quad . \quad$. $\quad . \quad 44$

24 Prey Fed to Young Swainson's Hawks in Franklin County,

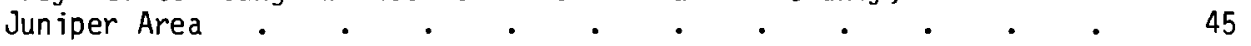

25 Prey Fed to Young Swainson's Hawks on the Yakima Firing Range Study Area

26 Prey Fed to Young Swainson's Hawks on the Hanford Site

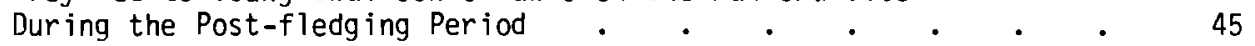

27 Prey of North American Swainson's Hawks $\quad$. . . . . . . . 46

28 Diet of the Ferruginous Hawk in Southeastern Washington . . 47

29 Diet of the Red-Tailed Hawk in Southeastern Washington . . 48

30 Diet of the Swainson's Hawk in Southeastern Washington . . 48

31 Residues of Organochlorine Pesticides, in Swainson's Hawk Eggs from the Hanford Site, Washington. 1976 ..$\quad$. 55

32 Residues of Organochlorine Pesticides in Selected

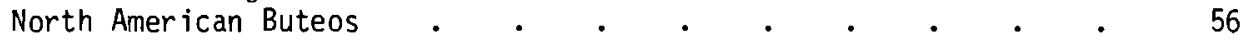


1 Patagial Wing-Marker Used on Adult and Fledgling

Swainson's Hawks

2 Radiotransmitter harness used on fledgling Swainson's Hawk . . 3

3 Radiotransmitter Backpack Mounted on Fledgling Swainson's Hawk $\quad 3$

4 Areas in southeastern Washington where Swainson's Hawks

were studied. All counties shown . . . . . . 5

5 The United States Department of Energy's Hanford Site showing locations of nesting sites $\quad . \quad$. $\quad . \quad$. $\quad . \quad 5$

6 Vegetation map of the Hanford Site $\quad$. . . . . . . . . 6

7 Hanford Site nest areas. (A) Sagebrush/Cheatgrass community, (B) Sagebrush-bitterbrush/Cheatgrass community. . . . . 7

8 Juniper study area in southern Franklin County. Big sagebrush/ bluebunch wheatgrass community with junipers interspersed.

9 Cropland in Pullman/Colfax study area. Wheat field with cottonwood in foreground and black locust in background show typical interspersion of woodlot.

Nest and egg of Swainson's Hawk

Development of nestling Swainson's Hawks, 4-10 days of age, from top to bottom: 4 days old--snow-white appearance of nestling in natal down, 1-2-, and 3-day-olds appear similar; 6 days o1d--second (preplumulae) down begins to replace natal down, imparting a grey cast to the young; 8 days old--adult female standing over young; 10 days old--primaries and secondaries beqin to emerge. (Note snake in nest.)

13 Development of nestling Swainson's Hawks, 12-18 days of age, from top to bottom: 12 days old--scapulars and primaries form conspicuous dark stripes against the light-colored downy plumage; 14 days old--retrices, scapulars, and remiges show as dark patches against the white downy plumage; 16 days old--breast patches begin to darken as feathers begin to unsheath; 18 days old

14 Development of nestling Swainson's Hawks, 20-26 days of age, from top to bottom: 20 days old--scapulars, wing coverts, remiges and retrices form a dark contrast against the 1 ightcolored downy head and belly; 22 days $01 d ; 24$ days $01 d ; 26$ days old--head still downy.

15 Development of young Swainson's Hawks, 28-34 days of age, from top to bottom: 28 days old--head mostly downy, showing first signs of feathering; 30 days old--head feathers about half grown, remiges and retrices about $2 / 3$ developed; 32 days old; 34 days old--feathers have completely grown in. 
Plant Communities of North America. (Adapted from Life Areas of North America, by John W. Aldrich, Journal of Wild life Management, Oct. 1963).

17 Breeding range of the Swainson's Hawk in North America. . . 15

18 Wintering range of the Swainson's Hawk in South America. . . 16

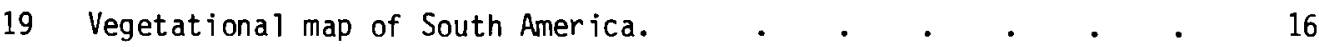

20 Breeding distribution of Swainson's Hawks in Washington, represented by dots, compiled from personal observations, study skin records, and published reports. Shaded area represents steppe grassland region.

21 Vegetation zones of the steppe region of Washington. $\quad$. $\quad$ - 19

22 Nesting Chronology of Swainson's Hawks in southeastern

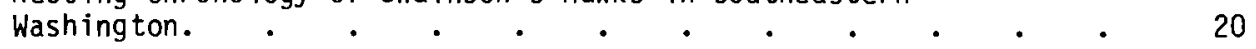

23 Female solicitation posture (sketch by author). . . . . . 22

24 Swainson's Hawks copulating. $\quad$. . . . . . . . . 22

25 Nest attentiveness of female Swainson's Hawks during the

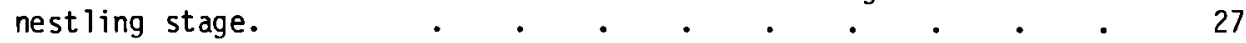

\begin{tabular}{l}
26 Nest attentiveness of male Swainson's Hawks during the \\
nestling stage.... \\
\hline
\end{tabular}

27 Frequency of brooding of nestlings by female Swainson's Hawks during daylight.

28 Frequency of shading of nestlings by female Swainson's Hawks

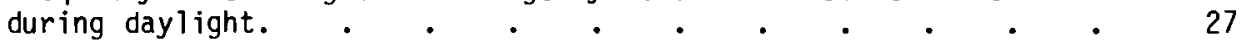

29 Typical shading position of female Swainson's Hawks. . . . . 28

30 Feeding record of nestling Swainson's Hawks. $\quad$. . . . . 28

31 Home ranges of fledgling Swainson's Hawks represented by dotted area. Dashed lines are land sections and represent distances

32 Sonograms of adult distress calls. (A) Male from nest site 19, Hanford Site. (B) Female from nest site 19, Hanford Site.

(C) Female from nest site 3, Hanford Site, (D) Male from nest site 3 , Hanford Site.

33 Home range size of adult male Swainson's Hawks represented by dotted areas. Dashed lines are land sections and represent distance in square miles.

34 Home range size of adult female Swainson's Hawks represented by dotted area. Dashed lines are land sections and represent distance in square miles. 


\section{ACKNOWLEDGMENTS}

Many of the ideas and concepts contained in this document have developed from research programs conducted by personnel in Pacific Northwest Laboratory's Ecological Sciences Department. These research programs have been supported by the U. S. Department of Energy's Office of Health and Environmental Research.

Appreciation is expressed to word processors, Karen Tallent and Robyn Kelso, to the editor, Naomi Sherer; to L. E. Rogers, L. L. Cadwe11, M. C. McShane, G. A. Bloomstrom and J. N. Allen for their technical and field assistance; and to Virginia Uresk for her assistance during the early phases of this study. 


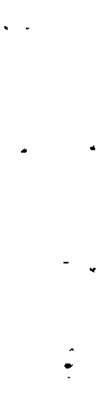


GEHAVIORAL ECOLOGY OF THE SWAINSON'S HAWK (Buteo SWainsoni)

IN WASHINGTON

INTRODUCTION

METHODS

The Swainson's Hawk (Buteo swainsoni) is the smallest Buteo inhabiting southeastern Washington and during the nesting season may be the most common of the large birds of prey (Plate I). It breeds throughout most of the arid regions of North America and west of the Mississippi River from northwest Mexico and Baja California to the Seward Peninsula in Alaska, but excluding the Pacific Coast north of Los Angeles, California (Brown and Amadon, 1968). The wintering range of the Swainson's Hawk is confined mainly to Argentina but a few winter in Florida. It makes the longest migration of all the large birds of prey of southeastern Washington.

Although the Swainson's Hawk does nest in North America, few comprehensive studies exist on its ecology and there appear to be no previous detailed investigations made in Washington. The major studies in North America were conducted in Colorado by 0 lendorff (1973a) and in Wyoming by Dunk le (1977). Smaller noteworthy works have been published on the species' nesting biology in Illinois (Keir, 1976), Utah (Platt, 1971; Smith and Murphy, 1973), Montana (Cameron, 1913), and Wyoming (Craighead and Craighead, 1956). Olendorff (1974) describes the courtship flight of the species and Cameron (1908), Bowles and Decker (1934), Bent (1961), and Dunk le (1977) discuss plumages. Skutch (1945) provides an account of migrations in Costa Rica and other areas of Central America. The limited Washington literature on this species includes reports on nesting by Bowles and Decker (1934) and on status and/or distribution by Edson (1908), Rathbun (1902), Dice (1918), Jewett et a 1. (1953), King (1953), Hudson and Yocom (1954), Larrison and Sonnenberg (1968), and Alcorn (1971).

Concern has been expressed for the we 1fare of this species (Marsha11, 1969; Dyrness et a1., 1975; Arib, 1976) and a closer look at this raptor is warranted.

The objective of this study was to examine in depth the nesting ecology and behavior of the Swainson's Hawk in its breeding range in Washington and to provide an overview of its life history in North and South America.

\section{GENERAL PROCEDURES}

Field work took place during five springsummer breeding seasons (April, 1973 September, 1977). During 1973 and 1974, field work consisted of collecting of data on productivity and food habits and of banding young hawks with U.S. Fish and Wildlife Service metal leg bands. Information was recorded on habitat types used for nesting, nest site characteristics (height of nest above ground, location of nest in the tree, tree species selected for nesting), and the kinds of materials used to construct nests. Color phases of adult birds were noted whenever possible.

In 1975, field observations of Swainson's Hawks were conducted nearly every day from April 1 through September 15. Blinds constructed at three nest sites allowed close observations of the hawks throughout the nesting season. Considerable attention was also devoted to other birds of prey nesting in southeastern Washington, particularly Ferruginous Hawks (Buteo regalis) and Redtailed Hawks (Buteo jamaicensis). Periodic visits to nests provided data on clutch size, hatching success and fledging success as well as information on food habits and behavior. These visits were restricted during the incubation period but thereafter were generally two visits per week. Once the young Swainson's Hawks hatched, timelapse cameras were used at three nests on the Department of Energy's Hanford Reservation (Hanford Site) to record the behavioral development and food habits of nestlings and parental behavior during the nestling stage (Fitzner, 1977).

Banding studies in 1975 were designed to provide data on local and distant movements of newly fledged young. Patagial wing markers (Fitzner, 1975) and federal metal leg bands were placed on hawks prior to fledging. The wing markers were fashioned from Herculoid-80, a vinyl coated nylon fabric, and were each given a letter and numeral mark for later identification of individual birds (Fig. 1). All inscriptions could be read from $100 \mathrm{~m}$ with $7 x$ binoculars. Patagial markers were visible at $300 \mathrm{~m}$ without the aid of binoculars. The 


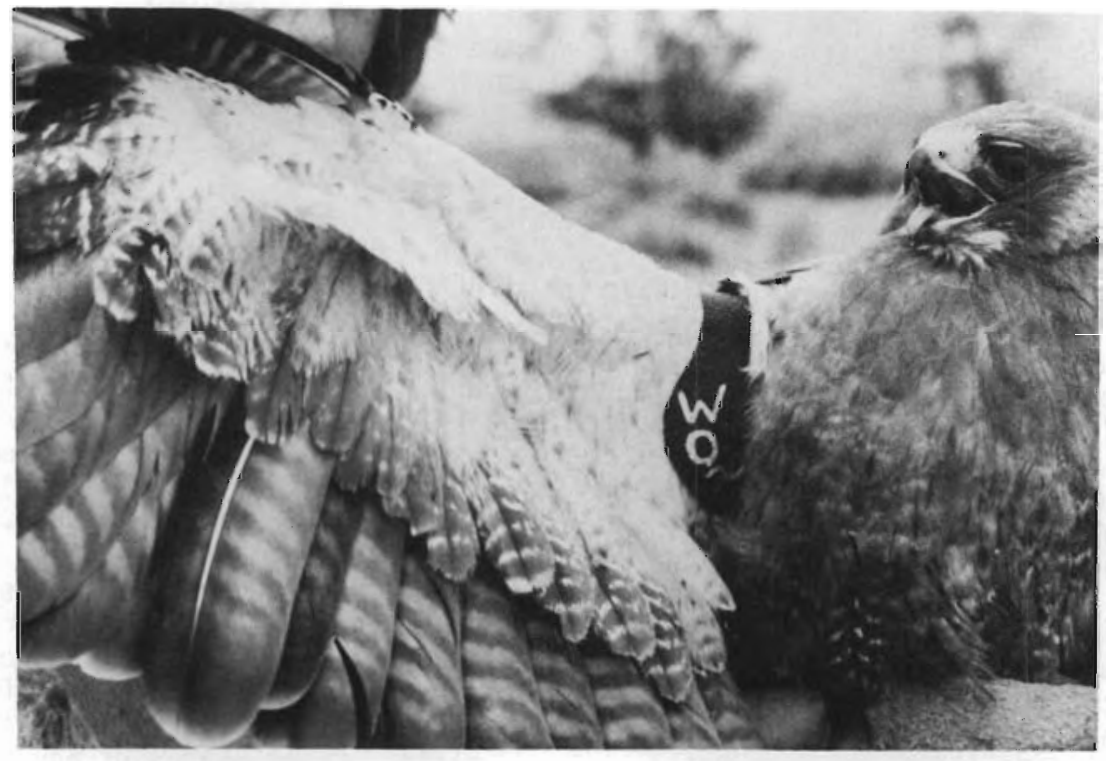

FIGURE 1. Patagial wing-marker used on adult and fledgling Swainson's hawks.

patagial markers were placed on the birds to facilitate spottings by bird watchers in North and South America. Notices of the banding and marking program were placed in a 11 major bird journals and a number of less we 11-known publications in Canada and the United States. One thousand fliers were also sent to universities, state game departments and federal fish and wildiife personne1, as we 11 as Audubon chapters, newspapers, power companies and bird watchers across North America. Three thousand circulars were printed in Spanish by the Argentina Department of Agriculture for distribution to their rural areas.

Food habits of Swainson's Hawks were investigated in Washington during the nestling period and post-fledging period. During nesting, techniques described by Errington (1932) and Moon (1949) were employed for data accumulation and analysis. Relative percent frequency estimates were calculated for each prey taxon on the basis of total number ident ified (Curtis and McIntosh, 1950).

During the post-fledging period, pellets of materials thrown out of the nest (castings) by both young and adult birds were gathered from roosting sites on the Hanford Site. Each pellet was pulled apart and the hair, scales, feathers, bones, and chitinous invertebrate parts were identified by comparison with material in Battelle, Pacif ic Northwest Laboratories' collections and with information provided by Mayer (1952). Each pellet's contents were tabulated and summed to provide relative percent frequency estimates for each prey taxon on the basis of total number identified (Curtis and McIntosh, 1950).

In 1976, the same pattern and methods used in 1975 were again followed. During this season, however, data on daily movements and territoriality of adults and fledged young were studied. Seven adult birds, three males and four females, were equipped with radio transmitter tail packages and 10 young were equipped with radiotransmitter back packages. Transmitters operated at frequencies ranging from 151.000 megacycles to 151.990 megacycles. Fitzner and Fitzner (1977) described the attachment procedures used for tail packages and discussed operating range. The back package transmitters $(22.0 \rightarrow 26.0 \mathrm{~g})$ were placed on young in the field when they were about six weeks old. The transmitters were held on the bird by a harness (Fig. 2). The harness was constructed of $0.5 \mathrm{~cm}$ diameter nylon tubing reinforced by 20 -gauge wire running inside the tubing. The transmitter was fitted on the bird's back by placing the posterior straps under each wing (adjacent to the bird's body) and then extending them forward, up, and over the leading edge of each wing and over the dorsum of the bird. The straps were then fastened with dissolvable gut suture so the transmitter would fall off in time. This attachment technique positioned the radiotransmitter on the bird's back between both wings, 


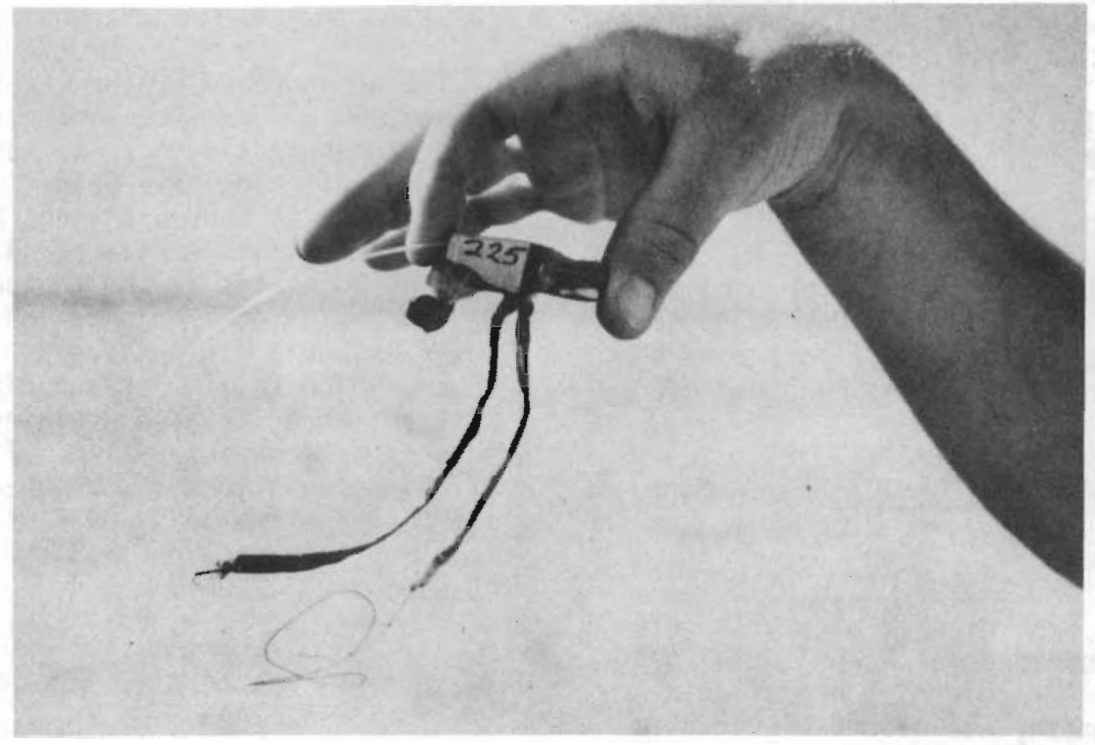

FIGURE 2. Radiotransmitter harness used on fledgling Swainson's Hawk.

and enabled the antenna to extend down the bird's back (Fig. 3).

A multiple-channel Cedar Creek receiver and a four-element Yagi antenna, both portable, were carried into the field to locate radiotagged birds. The antenna was directional and no triangulation was needed to locate birds.
Seven adults and 17 young were fitted with patagial markers in 1976. The marking of adults was intended to provide data on the extent to which these birds return to the same territory from one year to the next.

The seven radiotagged adults were weighed with a $1610 \mathrm{~g}$ capacity platform

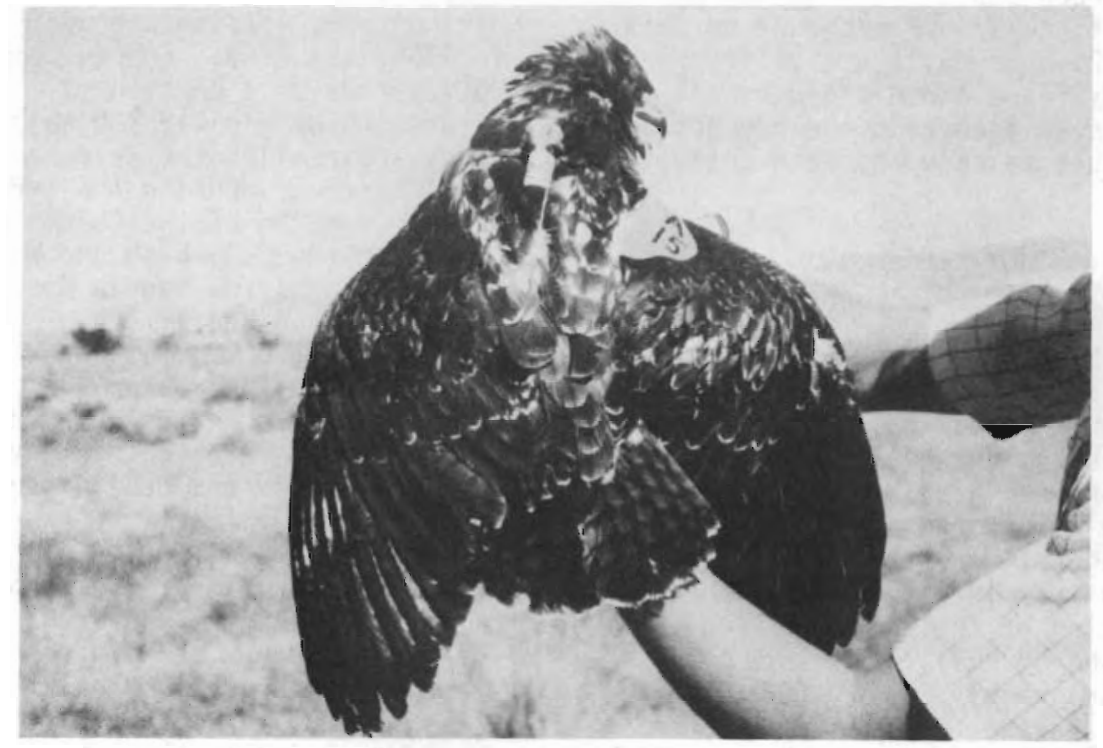

FIGURE 3. Radiotransmitter backpack mounted on fledgling Swainson's Hawk 
balance, and measurements ( $\mathrm{mm}$ ) were recorded for length of wing chord, tail, tarsi, middle toe, hind toe, bill from gape and culmen with cere (Baidwin et a1., 1931). Body weights were also recorded for three young whose ages were known. Length, width and weight $(\mathrm{g})$ of 10 freshly laid eggs were also determined.

In 1977, data were gathered primarily on productivity. Linear dimensions of 18 newly constructed nests were also recorded on the Hanford Site and young hawks were banded.

\section{CAPTURE AND ANALYTIC TECHNIQUES}

\section{Trapping}

Adult hawks were trapped with mist nets baited with stuffed Great Horned Owls (Bubo virginianus). A single mist net, $18.3 \bar{x}$ $3.1 \mathrm{~m} 10.2 \mathrm{~cm}$ mesh, was placed within $50 \mathrm{~m}$ of the nest tree. The ow 1 was placed approximately $1 \mathrm{~m}$ on either side of the net, $1 \mathrm{~m}$ above ground. A stooping hawk generally swerved upward in a parabolic path after hitting or nearly hitting the ow 1 and became entangled in the net.

Nestling hawks were all banded on the nest and no special trapping techniques other than climbing the nesting tree were necessary.

\section{Time-Lapse Film Analys is}

Super-8mm time-lapse film records were made at three nests in 1975. Single frames were exposed every 60 seconds. In analyzing the developed film, each frame was viewed on $\mathrm{a} 2 \times 2.5 \mathrm{~m}$ screen and the activities of young and adult hawks were recorded on data sheets. Each 24-hour day's activities were summed frame by frame and divided by all daylight frames to ascertain the percentage of daylight hours taken up by each activity.

\section{STUDY AREAS}

\section{GENERAL DESCRIPTION}

The study area discussed here is located in the southeastern quarter of Washington state, excluding the Blue Mountains. The climate is too arid to support trees, and the natural vegetation is classified as steppe (Daubenmire, 1970). Most of the native vegetation of the area has been either destroyed by cultivation and water impoundment, or great $7 y$ modified by fire and livestock grazing (Fitzner et al., 1977). Much of the unchanged area is channeled scabland, formed when glacial floods bared large tracts of basalt, and scoured canyons and deep valleys (USDI, 1973).

The arid steppe region consists of more than 6,000,000 ha (Daubenmire, 1970). The land slopes gently north to south from about $610 \mathrm{~m}$ in altitude near Grand Coulee Dam to about $120 \mathrm{~m}$ at the confluence of the Yakima, Snake, and Columbia Rivers. Although the Cascade Mountains $100 \mathrm{~km}$ to the west receive 350 to $450 \mathrm{~cm}$ of precipitation annually, the lower Columbia basin averages on ly 15 to $25 \mathrm{~cm}$, which falls mostly during $\mathrm{fall}$ and winter. Moderately cold winters and hot summers are characteristic. The daily mean of the coldest month is between -5.5 and $1.5^{\circ} \mathrm{C}$, while the dajly mean of the nottest month is between 18.5 and $24.5^{\circ} \mathrm{C}$. (Daubenmire, 1970).

\section{INTENSIVE STUDY AREAS}

Intensive investigation of the Swainson's Hawk was conducted in three areas (Fig. 4). The Hanford Site (Fig. 5) served as the principal study area and data were collected there from 1973 through 1977. The Juniper area in southern Franklin County (II) and the Pullman/Colfax area of Whitman County (III) were studied in 1975 on $7 y$.

Hanford Site

The Hanford Site lies at the southeastern end of the lower Columbia basin and consists of approximately $1476 \mathrm{~km}^{2}(147,715 \mathrm{ha})$ in Benton and Frank 1 in Counties. It is bordered by the Columbia River on the north and east and the Yakima River to the south. This site was established in 1943 as a national security area and was closed to agriculture, grazing and unofficial travel. In 1958, the Atomic Energy Commission (now DOE) set aside a portion $\left(311 \mathrm{~km}^{2}\right)$ of the site south of Highway 240 as an ecological study area called the Arid Lands Ecology (ALE) Reserve. During the early 1970 's, 12,950 ha north of the Columbia River were leased to the U.S. Fish and Wildlife Service to be known as the Saddle Mountain Refuge. The Washington Department of Game was also given a lease on 21,853 ha to be used for outdoor recreation. In 1977, the Hanford Reservation was set aside as a National Environmental Research Park by the U.S. Energy Research and Development Administration (nOw DOE).

The most prominent topographic feature of the site is Rattlesnake Mountain, on the western boundary, which rises to $1100 \mathrm{~m}$ above mean sea level. For $5 \mathrm{~km}$, the uniform crest of the mountain is $1100 \mathrm{~m} \mathrm{high,}$ dropping on its southeastern end to $125 \mathrm{~m}$ at the water gap of the Yakima River. Northwest of this large crest, a jumbled 


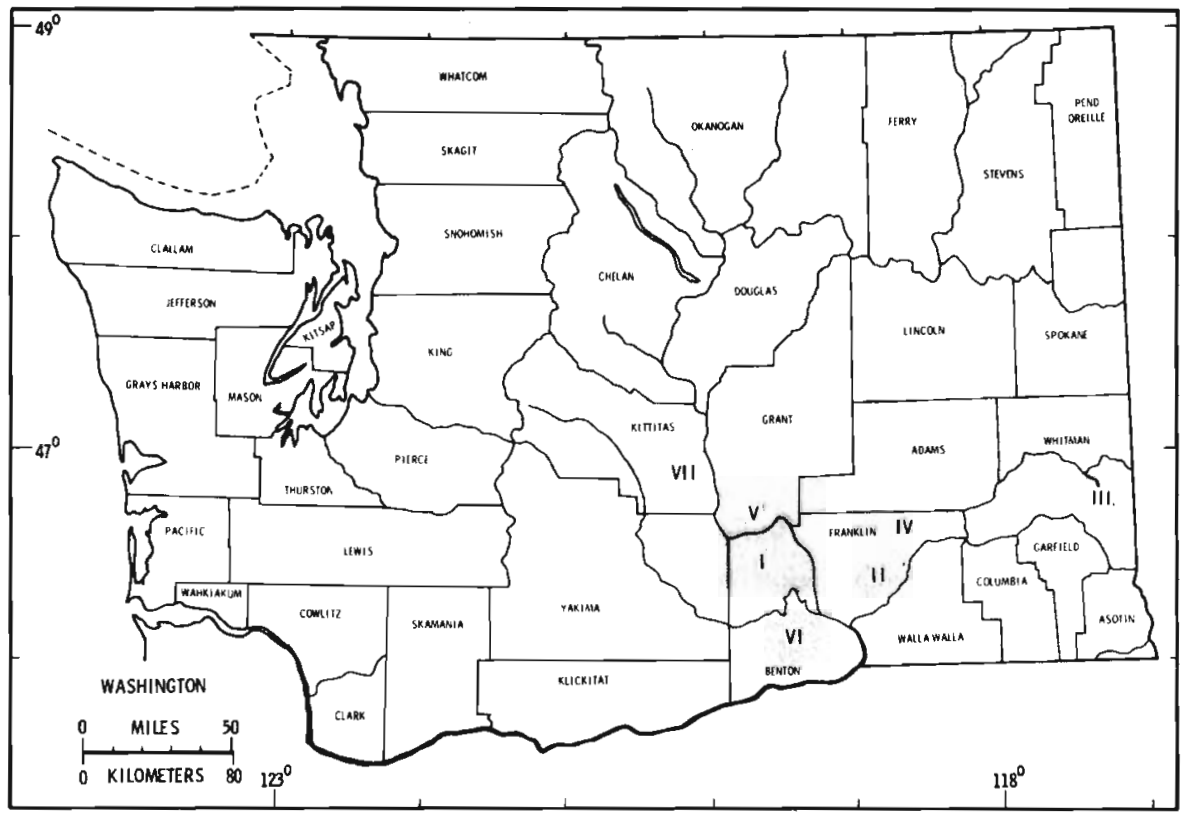

I HANFORD SITE

II JUNIPER AREA

III PULLMAN-COLFAX AREA

IV KAHLOTUS-WASHTUCNA APEA

VI BENTON CITY-HORSE HEAVEN HILLS AREA

VII YAKIMA FIRING RANGE

FIGURE 4. Areas in southeastern Washington where Swainson's Hawks were studied. All counties shown.

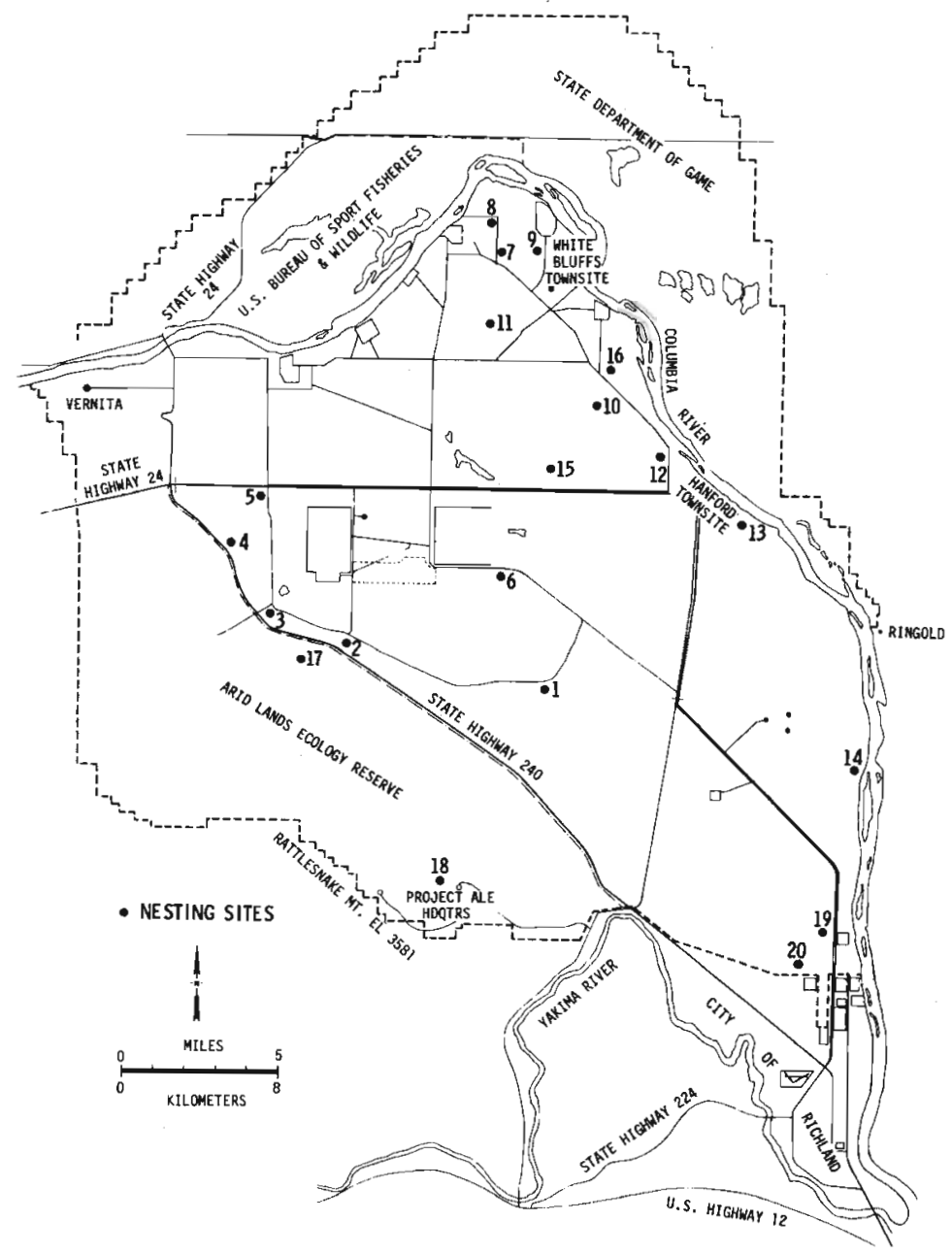

FIGURE 5. The United States Department of Energy's Hanford Site showing locations of nesting sites. 
topography, much less than $1000 \mathrm{~m}$ in elevation, merges with the northwest continuation of the Rattlesnake Hills (Brown, 1968). The north slope of the mountain drops steeply (about 25 degrees) onto the ALE Reserve to about $650 \mathrm{~m}$ elevation, then eases to 7 degrees down to about $350 \mathrm{~m}$, and finally slopes more gently to Cold Creek Valley at $150 \mathrm{~m}$. North of Cold Creek Valley $(150$ to $200 \mathrm{~m})$, the land surface rolls gently while rising to about $225 \mathrm{~m}$ on the crest of a broad ridge (Rickard et al., 1974). The Saddle Mountains rise in elevation to $925 \mathrm{~m}$ to the north. The Rattlesnake Hills and Saddle Mountains are separated by the Columbia River and an expanse of monotonous topography interrupted by an alignment of basaltic ridges (Gable Mountain and Gable Butte) which run east-west near the middle section of the Hanford Site. A series of steep walled cliffs along the north and east shores of the Columbia, upstream from the old Hanford town site, form another striking interruption. Unstabilized sand dunes occur as scattered is lands of various sized ranging from 1 ha to several thousand ha. The most extensive dune complex lies along the east bank of the Columbia River opposite Ringold.

The climate of the Hanford Site is strongly influenced by the Cascade Mountain Range to the west, which forms a barrier to moistureladen winter storms moving eastward from the Pacific Ocean. The resultant moisturedepleted air is warmed and further dried as it descends the eastern slopes of the Cascade Mountains (Thorp and Hinds, 1977).

Annual precipitation at the Hanford Meteorological Station averages $16.5 \mathrm{~cm}$, ranging from 7 to $30 \mathrm{~cm}$ over the past 30 years (Stone et a1., 1972). On the average, 60\% of the precipitation occurs between October and February. Precipitation decreases after January but increases again to a secondary maximum in June. The climate of the Hanford Site is characterized by hot, dry summers and moderately cold winters. July is the hottest and driest month while January is the wettest and coldest (Thorp and Hinds, 1977).

The vegetation of the Hanford Site can be mapped as three major types (Fig. 6). These are the sagebrush (Artemisia tridentata)bitterbrush (Purshia tridentata)/cheatgrass (Bromus tectorum) type, the sagebrush/ b Tuebunch wheatgrass (Agropyron spicatum) type and the sagebrush/cheatgrass vegetation type (Cline et al., 1977).

The natural vegetation mosaic has been scarred by numerous fires and by past agricultural practices. Abandoned agricultural

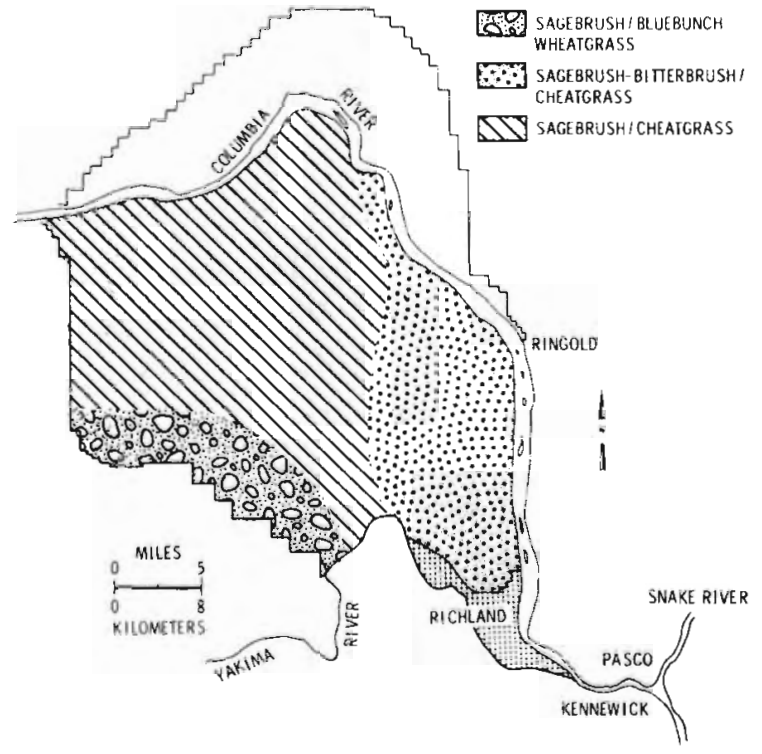

FIGURE 6. Vegetation map of the Hanford Site.

fields now dominated by cheatgrass and annual mustards are particularly noticeable. Trees appear erratically along both banks of the Columbia River from near shoreline to a few $\mathrm{kilometers} \mathrm{inland.} \mathrm{Most} \mathrm{of} \mathrm{these} \mathrm{trees}$ were planted for shade or orchards by early settlers and were abandoned over 30 years ago when the Hanford Reservation was created. Trees also occur in other isolated spots around the site where they were planted as shade for industrial facilities and military installations, now decommissioned. The common introduced trees are Chinese Elm (Ulmus sp.), Black Locust (Robinia pseudacacia), Cottonwood (Popu Tus sp.), Apricot (Prunus sp.) and Apple (Malus Sp.). The trees provide for almost al of the nesting of the Swainson's Hawk.

Nest sites tended to appear in the same areas year after year, facilitating location of adult pairs and their nests. Over the five years of study on the Hanford Site, a total of 20 nest sites were recorded but no more than 17 were ever used in a single year. The locations and reference numbers for all nest sites are shown in Fig. 5 and typical plant communities are shown in Fig. 7 .

The 34,804 ha of state and federally leased lands were not included in the intensive study of the Swainson's Hawk. These lands were examined in 1975, however, and data on nests found there are listed in the Productivity section of this report. The intensive study area on the Hanford Site therefore, encompasses $112,911 \mathrm{ha}$, including the ALE Reserve. 

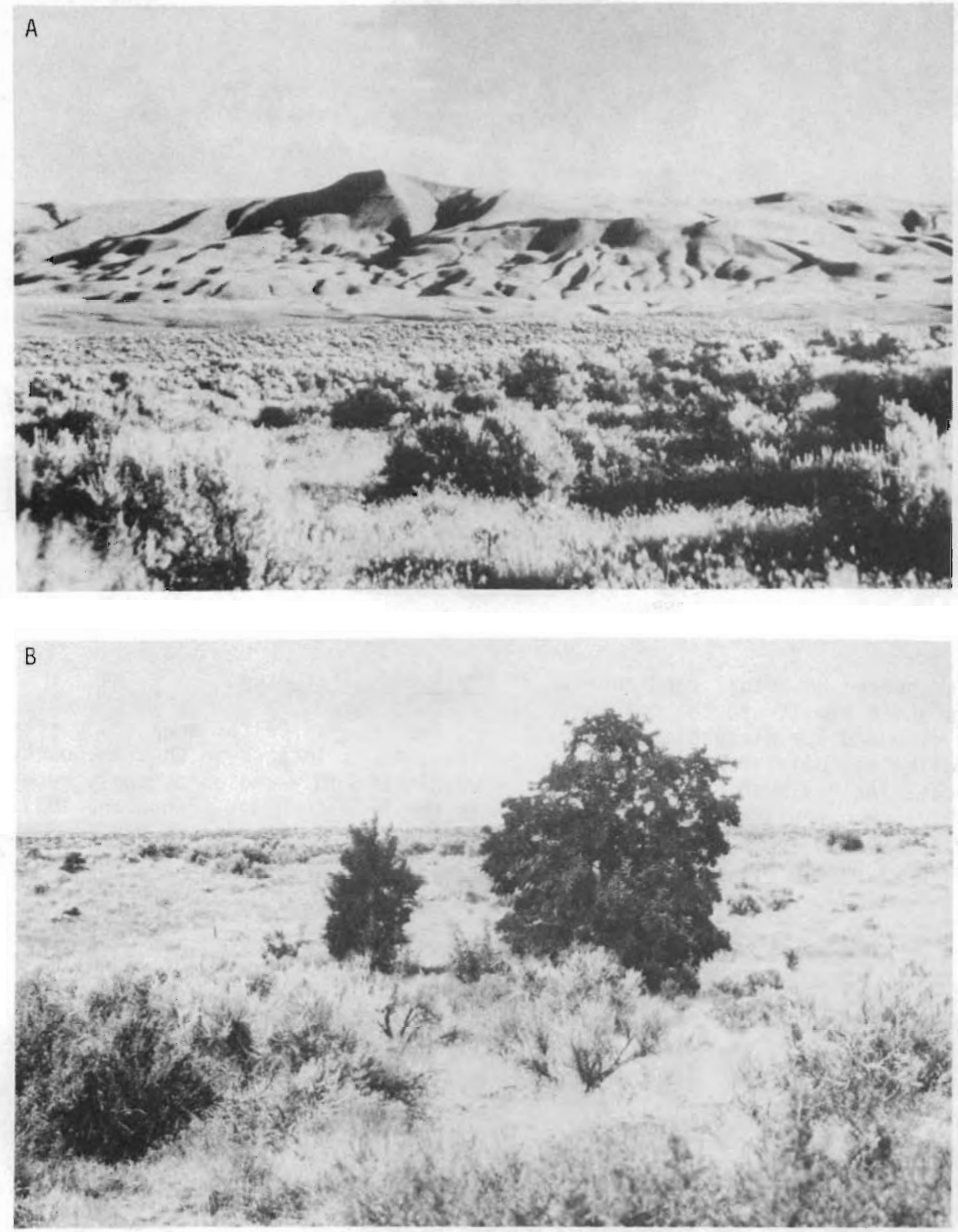

FIGURE 7. Hanford Site nest areas. (A) Sagebrush/Cheatgrass community, (B) Sagebrush-bitterbrush/Cheatgrass community.

\section{Juniper Area}

The Juniper area is located in southern Franklin County, Washington (Fig. 4). This area is approximately $117 \mathrm{~km}^{2}$ in size and is situated in townships 30 and 11 North, Ranges 31 and 32 East. Much of this land is administered by the U.S. Bureau of Land Management (BL.M). Figure 8 shows plant community of the area. Approximately $22 \mathrm{~km}^{2}$ of the area, locally known as the Juniper Forest, is designated as a "no vehicle" area by the BLM. This area was fenced and posted to exclude motorized trespass.

The topography of the Juniper area consists of gently rolling hills of glaciofluvial deposited sand. Less than one-fifth 


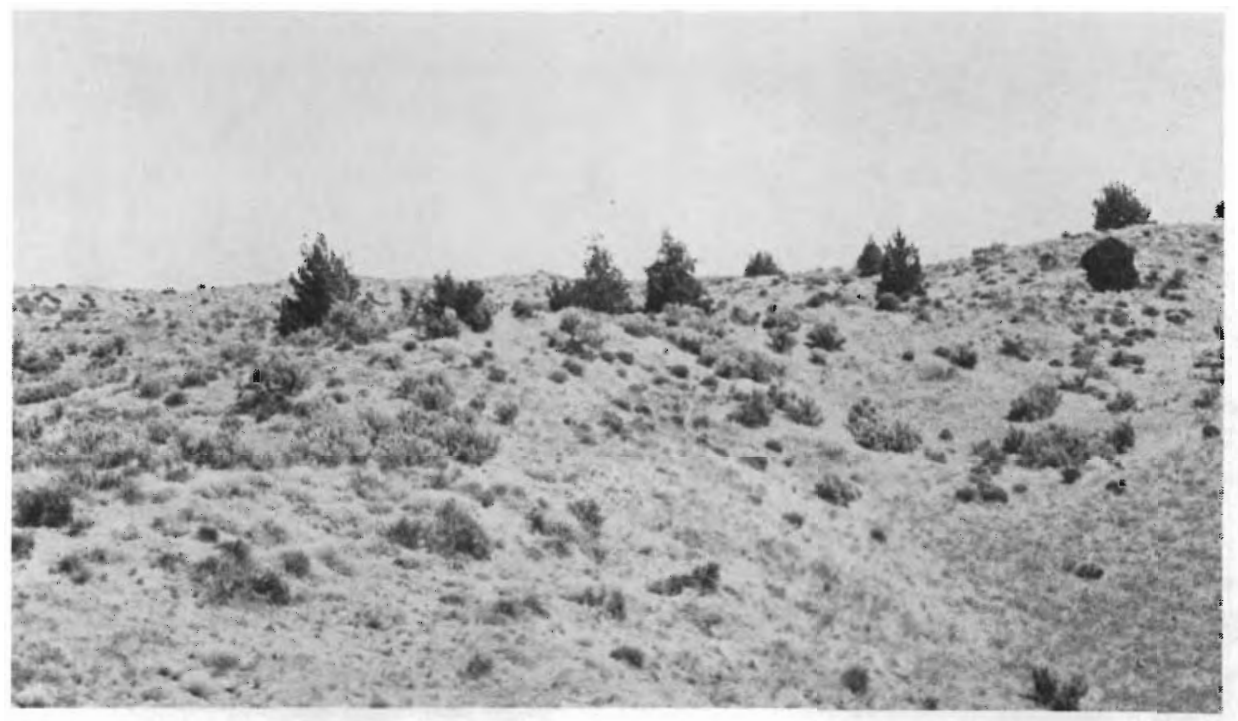

FIGURE 8. Juniper study area in southern Franklin County. Big sagebrush/bluebunch wheatgrass community with junipers interspersed.

of the area is covered by actual sand dunes. The climate is quite similar to the nearby Hanford study site and the discussion of the Hanford Site climate applies to this area as we 11. The vegetation has been described by Daubenmire (1970), who considers the area predominantly an association of big sagebrush and bluebunch wheatgrass.

\section{Pul1man/Colfax Area}

The Pullman/Colfax area study site (Fig. 4) is located in Whitman County, Washington in a region commonly referred to as the Palouse Hills (Fenneman, 1931). The topography of the area is one of dune-like hills formed from loessial deposits of pleistocene derivation (Fig. 9). Relief in

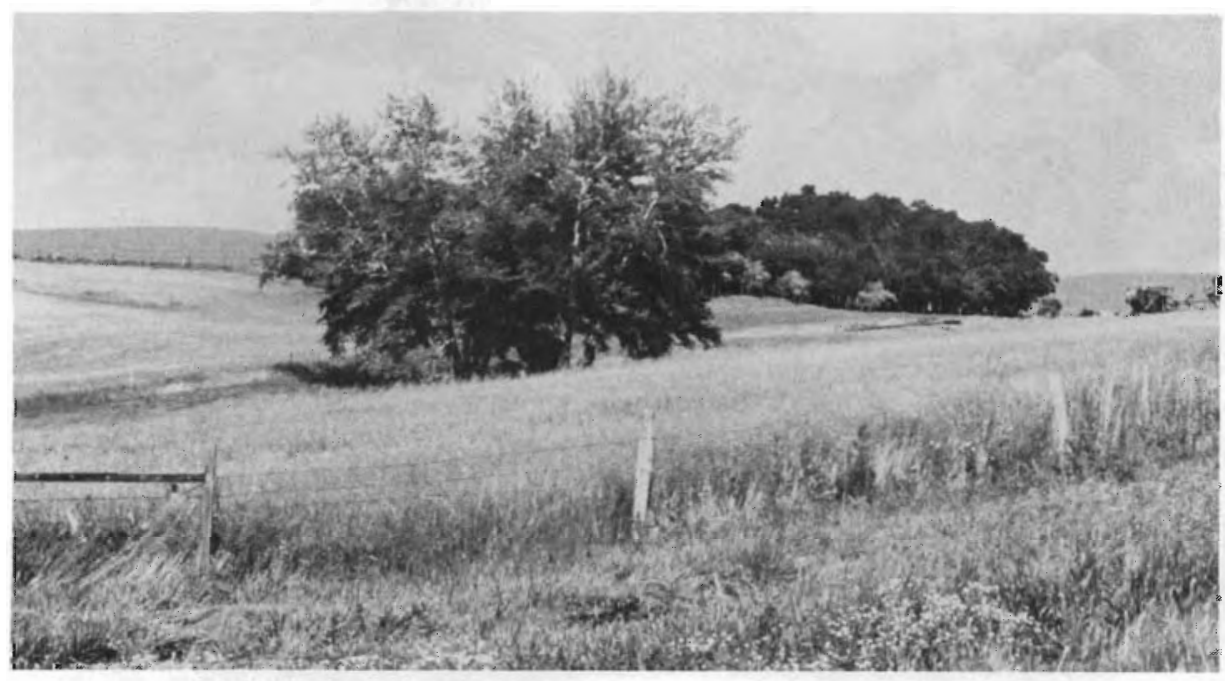

FIgURE 9. Cropland in Pullman/Colfax study area. Wheat field with cottonwood in foreground and black locust in background show typical interspersion of woodlot. 
the area is slight, rarely exceeding $33 \mathrm{~m}$ in the rolling uplands (King, 1953). Two hills, Kamiak Butte and Smoot $\mathrm{Hill}$ with the Ringo Buttes, are prominent topographic features in the area.

The climate in the Pullman/Colfax area is characterized by wet, cool winters and warm, dry summers. Rainfall occurs primarily between mid-0ctober and 1ate March and averages $20 \mathrm{~cm}$ annual1y (USDA, 1941). Temperature averages for Pullman in January and July are $-1.9^{\circ} \mathrm{C}$ and $22.2^{\circ} \mathrm{C}$ respectively.

The Pullman/Colfax area is a productive agricultural area and an important wheatraising region of the United States. King (1953) stated that small farms were being consolidated into larger, more efficient farms and more and more land was falling to cultivation. Only a few small remnants of native vegetation exist. Large expanses of cropland are interrupted by those few trees planted to retard soil erosion or to provide shade. Small streamside thickets of Hawthorn (Crataegus douglasii), Willow (Salix sp.) and B Tack Cottonwood (Populus trichocorpa) also occur in the area. Occasionally Ponderosa Pines (Pinus ponderosa) occur singly or in small clumps on the lower north exposures of nills. Trees either planted by man or naturally seeded provide nesting sites for the Swainson's Hawk.

\section{MORPHOLOGY OF THE SWAINSON'S HAWK}

\section{ADULTS}

A sample of three adult male and four adult female Swainson's Hawks (sexes had been previously determined from behavioral observations during the nesting season) were banded in 1976 on the Hanford Site and their measurements and weights were recorded. Table 1 presents the data for the seven birds and provides the calculated $F$ statistics for a one-way analysis of variance. The null hypothesis of no difference between sexes was rejected if the alpha value was less than 0.05. On7y four variables - wing chord, bill from gape (beak side length), cuimen from cere (beak top length) and weight - differed significantly. Thus, the limited samp ie suggests that these four features may be useful to determine the sex of adult Swainson's Hawks.

\section{$\underline{E G G S}$}

The eggs of the Swainson's Hawk (Fiq. 10) vary slightly in shape, but are generally oval. The color is paie bluegreen when fresh, fading to dull white within a few days after being laid; some are irreaularly and sparingly spotted with various shades of brown. Heavily marked eggs were not observed during this study.

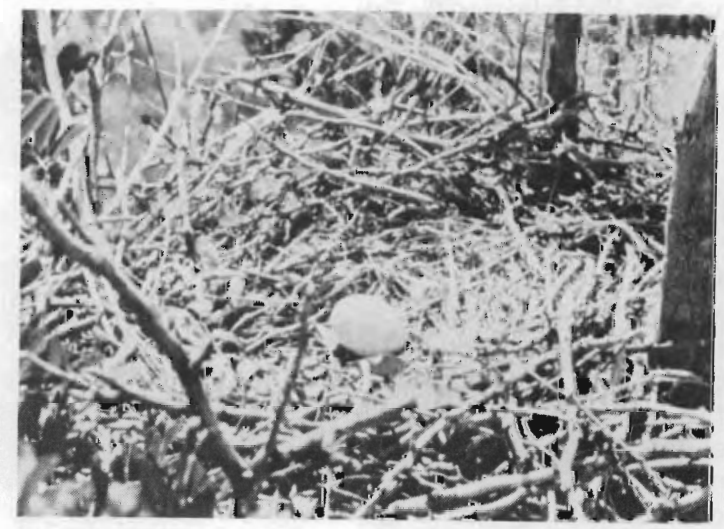

FIGURE 10. Nest and egg of Swainson's Hawk.

Measurements of 11 freshiy laid eggs from the Hanford Site are presented in Table 2. The mean length and width in millimeters were $55.9+$ S.E. 0.52 and $43.0 \pm$ S.E. 0.34, respective $\overline{7} y$, while the mean we ight was 51.2 \& S.E. $0.58 \mathrm{~g}$. Bent (1961) reports

TABLE 1. Measurements (mm) and Weights ( $\mathrm{g}$ ) of Adult Swainson's Hawks on the Hanford Site

\begin{tabular}{|c|c|c|c|c|c|c|c|c|c|c|c|}
\hline \multicolumn{5}{|c|}{ Adult Female } & \multicolumn{6}{|c|}{ Adult Male } & \\
\hline & w02 & =W03 & \#W04 & $\bar{x} \pm S . E$. & "W01 & \#W05 & \#W06 & :F07 & $\bar{x} \pm S . E$. & F & $\alpha$ \\
\hline Wing Chord & 391 & 395 & 365 & $383.7 \div 9.40$ & 419 & 425 & 420 & 422 & $421.5 \div 1.33$ & 22.24 & 0.0135 \\
\hline Tail & 202 & 208 & 215 & $208.3 \pm 3.76$ & 213 & 243 & 215 & 233 & $226.0 \pm 7.23$ & 3.75 & 0.1583 \\
\hline Tarst & 81 & 80 & 79.6 & $80.2 \div 0.42$ & 89 & 82.3 & 81,9 & 81.2 & $83.6 \pm 1.81$ & 2.44 & 0.2349 \\
\hline Midale Toe & 32 & 35 & 33.2 & $33.4 \pm 0.87$ & 39 & 39.2 & 35.4 & 35.4 & $37.3 \pm 1.07$ & 6.95 & 0.0778 \\
\hline Hind Toe & 17.5 & 20.2 & 19.7 & $19.1 \pm 0.83$ & 24 & 23.6 & 21.0 & 20.3 & $22.23 \pm 0.92$ & 5.70 & 0.0996 \\
\hline $\begin{array}{l}\text { Bill from } \\
\text { Gape }\end{array}$ & 38 & 42 & 36.5 & $38.8 \pm 1.64$ & 44 & 43.3 & 45 & 43.5 & $43.95 \div 0.38$ & 12.54 & 0.0339 \\
\hline $\begin{array}{l}\text { Cuinen with } \\
\text { Cere }\end{array}$ & 32.5 & 33.9 & 32.1 & $32.8 \pm 0.55$ & 36 & 34.2 & 36 & 35.2 & $35.4 \pm 0.43$ & 13.65 & 0.0298 \\
\hline Weight, g & 717.8 & 813.6 & 709.8 & $747.1 \pm 0.33 .35$ & 1080.35 & 975.0 & 1005.5 & 970.57 & $1007.9 \pm 25.38$ & 40.48 & 0.0047 \\
\hline
\end{tabular}


TABLE 2. Egg Length, width and Weight in the Swainson's Hawk

\begin{tabular}{|c|c|c|c|}
\hline $\begin{array}{l}\text { Egg } \\
\text { Number }\end{array}$ & $\begin{array}{l}\text { Length } \\
(\mathrm{mm})\end{array}$ & $\begin{array}{r}\text { Width } \\
(\mathrm{mm})\end{array}$ & $\begin{array}{l}\text { Weight } \\
(\mathrm{g})\end{array}$ \\
\hline & 54.0 & 43.8 & 50.0 \\
\hline 2 & 52.7 & 43.1 & 49.0 \\
\hline 3 & 56.5 & 44.6 & 54.0 \\
\hline 4 & 57.3 & 44.9 & 53.0 \\
\hline 5 & 56.6 & 43.7 & 50.0 \\
\hline 6 & 56.9 & 43.1 & 48.0 \\
\hline 7 & 55.0 & 41.8 & 51.0 \\
\hline 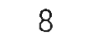 & 54.1 & 42.4 & 50.0 \\
\hline 9 & 58.6 & 42.0 & 53.0 \\
\hline 10 & 56.3 & 41.9 & 52.0 \\
\hline 11 & 56.8 & 41.7 & 53.0 \\
\hline
\end{tabular}

the average lengths and widths of 166 eggs in the United States Nationa 7 museum as 56.5 and $44.0 \mathrm{~mm}$ respectively, with a range of length from 50.0 to $62.0 \mathrm{~mm}$ and a width of 39.5 to $47.5 \mathrm{~mm}$. Weights were not reported.

\section{YOUNG}

The hatching weights of two youna from different nests were 43.0 grams each. A young bird within eight hours of hatching weighed $53.0 \mathrm{~g}$ while the weight of a bird between 36 and 48 hours old was $62.0 \mathrm{~g}$. When first hatched, young were covered with pale white down (Fig. 11). At about 9 or 10 days of age, the first signs of the primaries and secondaries appeared and the white down took on a grayish cast. Dark feathers: remiges, retrices, scapulars, and tertials were very prominent around 14 days of age and sharply contrasted with the downy portions of the body (Plate II). The development of feathers proceeded rapidiy, with the head, neck center of the breast, and flanks beina the last areas of the body to feather out.

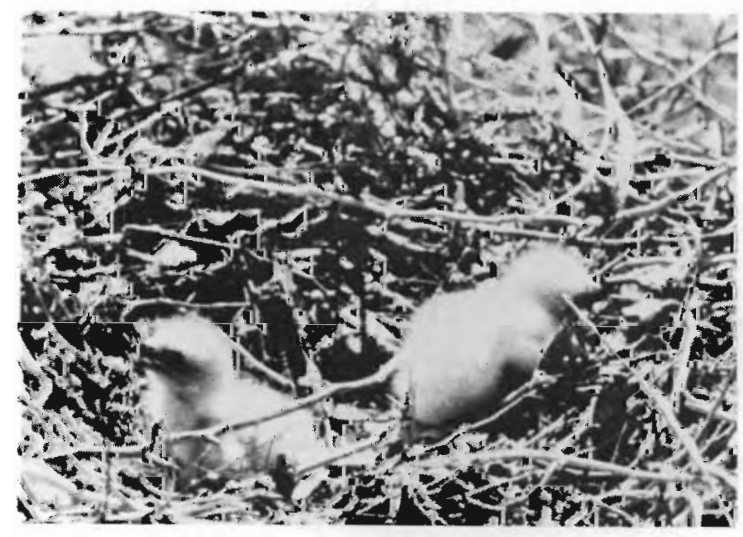

FIGURE 11. Day-old downy Swainson's Hawk Young.

Figures 12-15 show development of the young at two-day intervals, from the four-day-old downy young to the fledging stage.
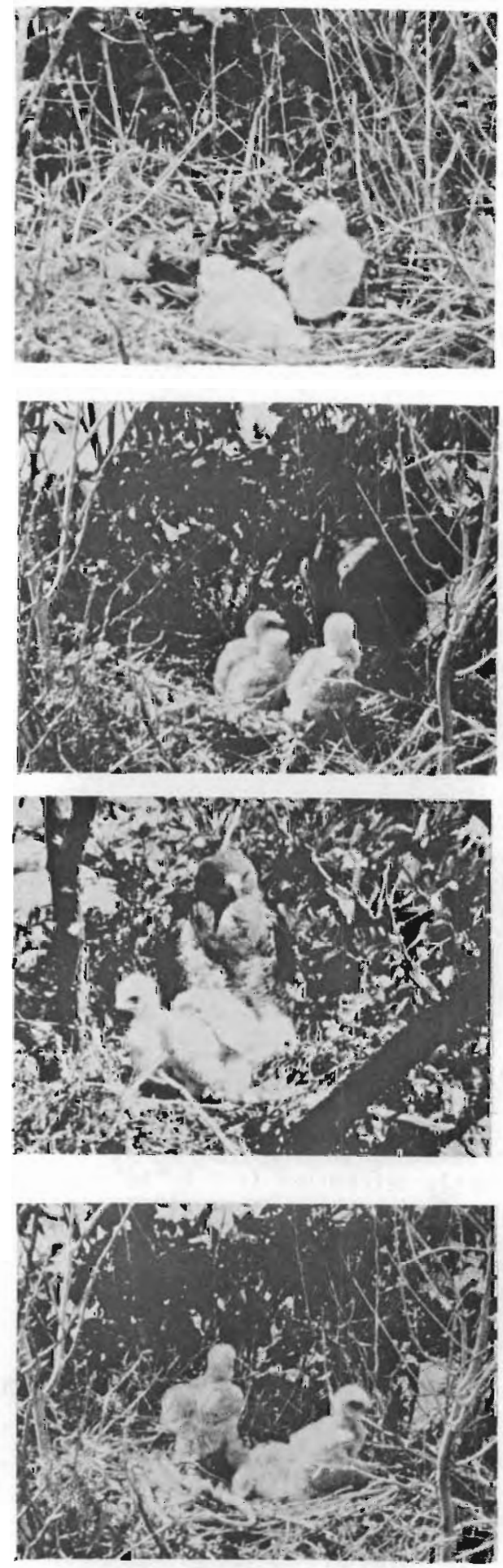

FIGURE 12. Development of nestling Swainson's Hawks, 4-10 days of age, from top to bottom: 4 days old--snow-white appearance of nestling in natal down, 1-2-, and 3-day-olds appear similar; 6 days old--second (preplumulae) down begins to replace natal down, imparting a grey cast to the young; 8 days old--adult female standing over voung; 10 days old-primaries and secondaries beg in to emerge. (Note snake in nest.) 

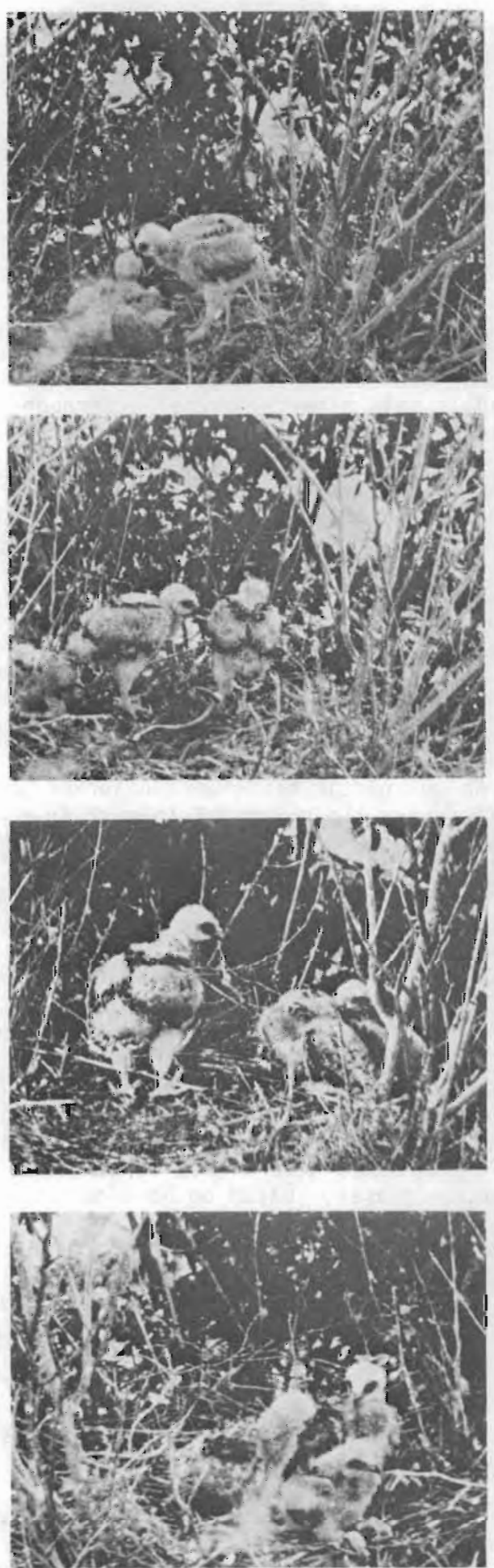

FIGURE 13. Development of nestling Swainson's Hawks, 12-18 days of age, from top to bottom: 12 days old--scapulars and primaries form conspicuous dark stripes against the lightcolored downy plumage; 14 days old--retrices, scapulars, and remiges show as dark patches against the white downy plumage; 16 days old--breast patches beg in to darken as feathers begin to unsheath; 18 days old.
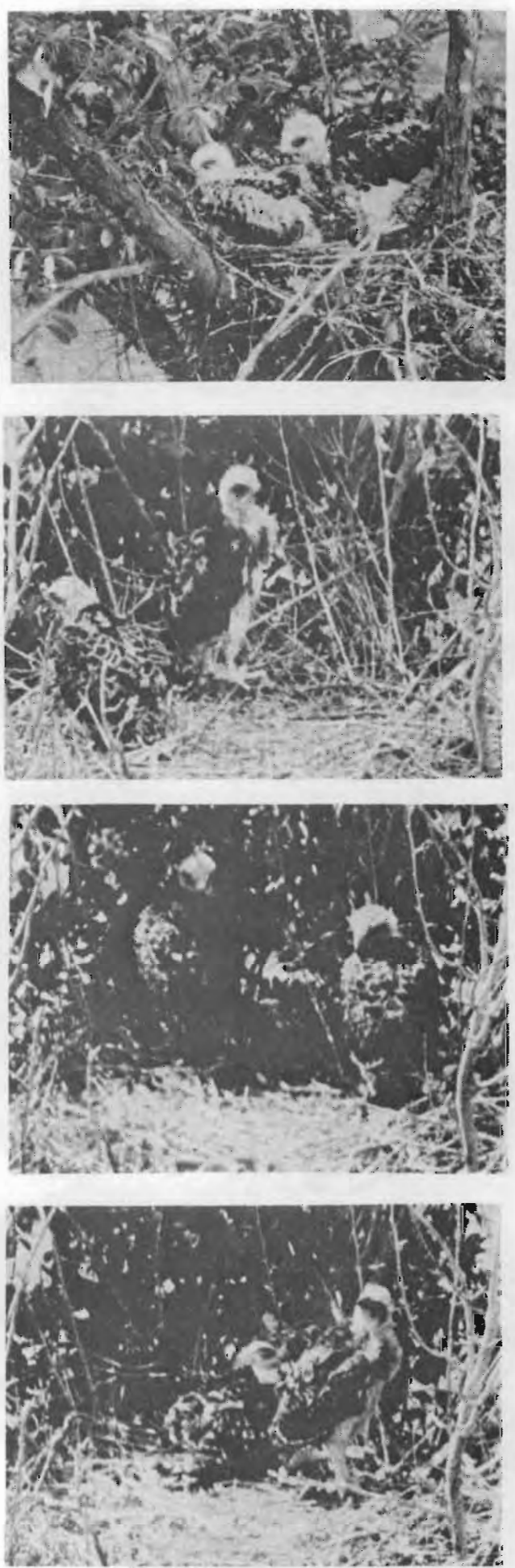

FIGURE 14. Development of nestling Swainson's Hawks, 20-26 days of age, from top to bottom: 20 days old--scapulars, wing coverts, remiges and retrices form a dark contrast against the light-colored downy head and be $11 y$; 22 days old; 24 days $01 d ; 26$ days oild--head sti11 downy. 

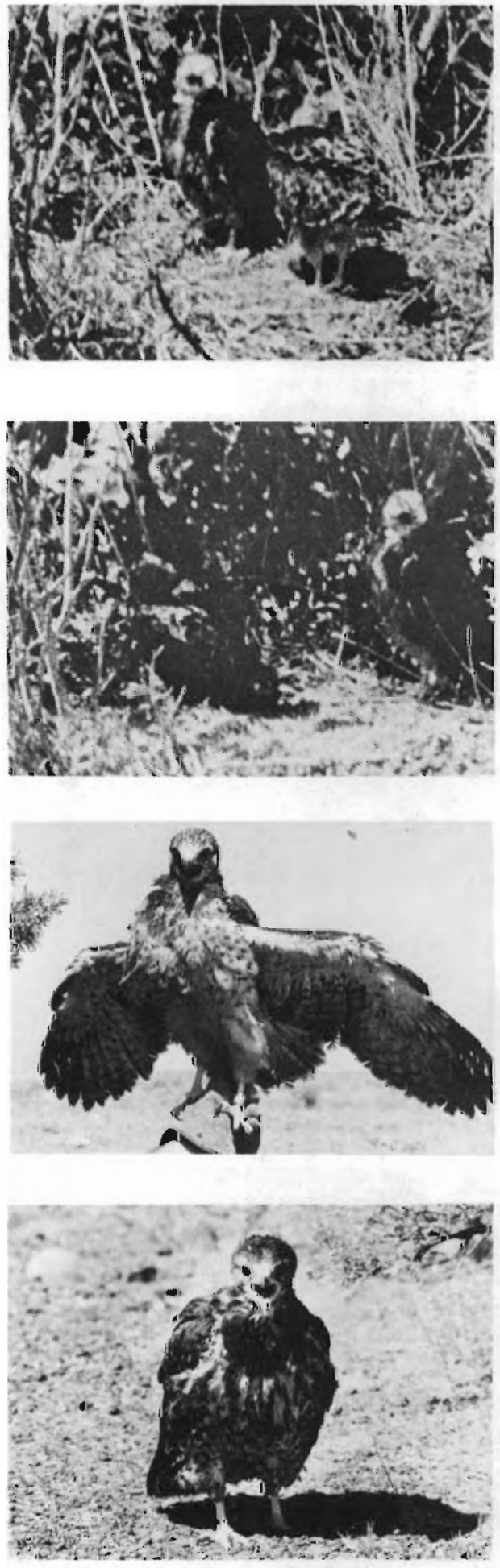

FIGURE 15. Development of young Swainson's Hawks, 28-34 days of age, from top to bottom: 28 days old--head mostly downy, showing first signs of feathering; 30 days old--head feathers about half grown, remiges and retrices about $2 / 3$ developed; 32 days old; 34 days old--feathers have completely grown in.

\section{COLOR PHASES}

\section{ADULT PLUMAGES}

Bent (1961) identified three color phases in Swainson's Hawks: light, extreme melanistic, and erythristic. Intermediates between their color phases were also noted. Cameron (1908) noted the same variation in color phases and attempted to relate these color differences to age and sex. He believed that the light phase was only assumed by the adult male after progressing through a succession of brown moults. This progression to the adult plumage was thought to take four or five years. Bowles and Decker (1934) noted two color phases, the light and dark, and classified the intermediate birds as liaht. Dunk le (1977) adopted this same classification scheme.

Adult Swainson's Hawks in southeastern Washington exhibited two distinctly different color phases, which I have termed light and dark. the dark phase observed was not a true melanistic, but rather a dark rust color. No melanistic birds were observed in the field during the course of this study. One melanistic study skin of an adult female (Plate III) was observed in the Washington State University Connor Museum, Pullman (Specimen No. 57-165). Between the light and dark rust extremes is an intermediate phase, which I have subdivided into intermediate light and intermediate dark phases. Separation into these two categories is based on the degree of dark marking on the bird's underside. Plate IV shows the intermediate color phases and places them into either the intermediate light or intermediate dark categories. Both sexes have light, dark, or intermediate phases. Based on banding studies conducted in 1976, I would not conclude that the intermediate phase represents immature birds as proposed by Cameron (1908). I marked six breeding intermediates with blue patagial wing markers. Five of the six returned in 1977 to the same nest sites used the previous year and these were still intermediate in color phase, suggesting that the color does not change with maturity, at least within a year's duration.

In 34 pairs where I recorded color phase, males consisted of 12 light, 7 intermediate light, 5 intermediate dark and 10 dark phase. The 34 females were comprised of 7 light, 15 intermediate light, 2 intermediate dark and 10 dark phase. To determine whether mating occurred randomly or nonrandomly in regard to color phase, the 10 pairings possible with the four color phases were analyzed statistically, and found not to deviate significantly from random $(P<0.05)$ chi-square test. Dunkle (1977) in examining 42 pair of Swainson's Hawks, found that 29 pairs were 
light phase, 6 were dark and 7 were mixed. A chi-square test was employed to determine if there was a preference for mates of the same color phase. A significant chi-square value was obtained and a preference was assumed.

\section{JUVENILE PLUMAGES}

None of the fledglings banded with U.S. Fish and Wildlife service metal leg bands or with patagial wing markers have been recover ed after their first winter. Data on plumage changes as young progress to adulthood are therefore lacking. Bent (1961) described the probable progression which occurs in moults, but more conclusive data are needed. Apparently, young birds beg in a moult from the first year plumage (Plate $V$ ) to the second year plumage in April or May the year after hatching. The moult begins with the primaries and tail, and continues with a body moult during summer. The moult is probably not completed until September or later (Bent, 1961). Of two young I kept in captivity, this same pattern occurred. Neither of these birds exhibited the full adult plumage after the ir first moult, as their primaries, secondaries and tail feathers were adult in character but their breast feathers were mostly juvenile in color. Neither of these birds was kept through the second moult but I suspect with Bent (1961) that this second summer moult produces the adult plumage.

\section{DISTRIBUTION IN NORTH AND SOUTH AMERICA}

\section{BREEDING RANGE}

Brown and Amadon (1968, p. 585) define the following as the breeding range of the Swainson's Hawk: "...western North America, in the Great Plains and arid regions, north sparingly to interior Alaska, and south to northern Mexico. Usually it is found at low or moderate elevations, but on migration a few follow the higher mountain ridges and meadows both in the Rockies and Andes."

Swainson's Hawks arrive on North American nesting grounds from March through April (Bent, 1961) with early April probably representing the norm. The majority of these hawks nest in the grassland and desert regions of western United States and Canada extending from Alaska (Brown and Amadon, 1968) to Manitoba (Seton, 1890; Criddle, 1915; Taverner, 1934), western Minnesota, and California (Sharp, 1902; Grinnel1, 1915; Dawson, 1923; Grinne 11 and Wythe, 1927; Willett, 1933; Bond, 1939), southcentral Texas (Oberholser, 1974), and uncommonly, Illinois (Hess, 1910; Bu11, 1958) and
Missouri (A.0.U., 1957). Keir (1976) believes that this species presently occurs more commonly in Illinois than the literature would indicate. His observations on seven nesting pairs within $85 \mathrm{~km}$ of downtown Chicago during 1973 and 1974 indicate the possibility that a permanent breeding population may be established in parts of northeastern Illinois. Breeding records are also reported for Wyoming (McCreary, 1939; Williams and Matteson, 1948; Dunk le, 1977), Montana (Cameron, 1907, 1913; Saunders, 1921), Nebraska (Mathisen and Mathisen, 1968), Nevada (Linsdale, 1936; Gullion et al., 1959), Idaho, (Arvey, 1940: 01son, 1942; Burleigh, 1972; Craig and Trost, 1976), Utah (Platt, 1971; Smith and Murphy, 1973), Colorado (Aiken and Warren, 1914; Olendorff, 1973a), Washington (Dawson and Bowles, 1909; Dice, 1918; Kitchin, 1934; Bowles and Decker, 1934; Booth, 1952; Jewett et a1., 1953; King, 1953; Hudson and Yucom, 1954), Oregon (Gabrielson and Jewett, 1970; Farner, 1954), Arizona (Phillips et al., 1964), Ok lahoma (Sutton, 1967), North Dakota (Bent, 1961; Stewart and Kantrud, 1972) and Kansas (White, 1965).

Figure 16 shows the plant communities of North America and Figure 17 shows the breeding range of the Swainson's Hawk. Clearly this species nests primarily in treeless and semi-treeless regions from midwestern tallgrass prairie to desert habitats.

\section{WINTERING RANGE}

The Swainson's Hawk winters principally in the northern provinces of Argentina (casually to Rio Negro) and exceptionally in Costa Rica, Panama, and Colombia. It has also been reported in Venezuela, Ecuador, Peru, eastern Brazil in eastern Amazonas, Maranhuo, Parana, Rio Grande do Su1, Uruguay, and eastern Bolivia in Santa Cruz (B)ake, 1977; Meyer De Schauensee, 1970).

A small population of Swainson's Hawks winter in Florida. Several dozen birds, up to 100 (rarely), occur there from March to October (Greene, 1946; Bailey, 1931; Sprunt, 1954; Brown and Amadon, 1968; Browning, 1974). Apparently most of the Florida birds are immatures (Brown and Amadon, 1968; Browning, 1974).

On the basis of site records (Amadon, 1964 ; Johnston, 1965; Sutton, 1967; Lowery, 1960; Browning, 1974), study skins and banding records (Browning, 1974), it has been suggested that the winter distribution of the Swainson's Hawk should include Florida and other places in North America. Sight records and banding records of wintering 


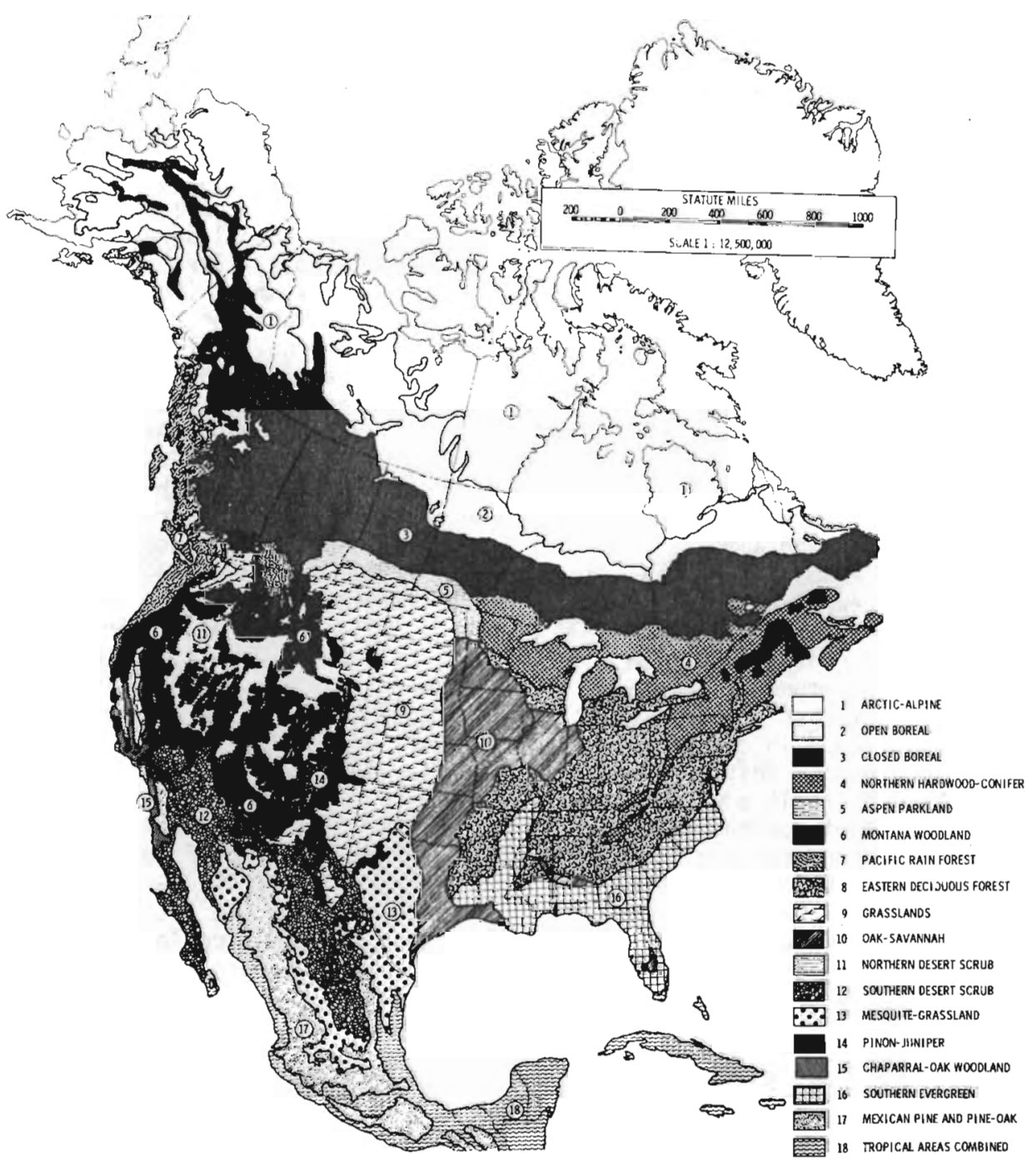

FIGURE 16. Plant Communities of North America. (Adapted from Life Areas of North America, by John W. Aldrich, Journal of Wildlife Management, Oct. 1963).

Swainson's Hawks should be met with some skepticism, however, since Swainson's Hawks are very difficult to identify. The tremendous variation in plumages in the species often leads to confusion with other similar Buteos. only seven of the winter record are from museum specimens (Browning, 1974): California (2), New Mexico (1), Texas (2), Louisiana (1), and Florida (1). These records show that the Swainson's Hawk does indeed winter in several of the southern states of the United States, but the infrequency of recorded occurrences would also indicate that the species is a rather uncommon winter resident.

Olrog (1976, Ornothologist Institute Migue 1 Li110, Tucuman, Argentina, personal communication) observed flocks of 40 and 16 birds, all yearlings, arriving at San
Clemente de 1 Tuyu, Argentina on 25 November 1963 and 23 November 1967, respective1y. The birds arrived from a high altitude and dropped down to groups of small trees, where they roosted. They were completely exhausted and could be caught by hand. Two specimens collected on each date had empty stomachs. These birds were thought to be late-arriving migrants from the north. In November of 1962, 01rog (1967) observed a group of 60 birds near San Antonio, Argentina. These hawks spent the night in a tall tree. The following morning almost all of the birds flew off toward the Atlantic Ocean and the few remaining stragglers also left within a few days. On their wintering grounds, the birds often remained in flocks but singles were not uncommon. Vasina (Ornithologist, Museum Argentino de Ciencias Naturales, Buenos Aires, Argentina) observed 50 birds 


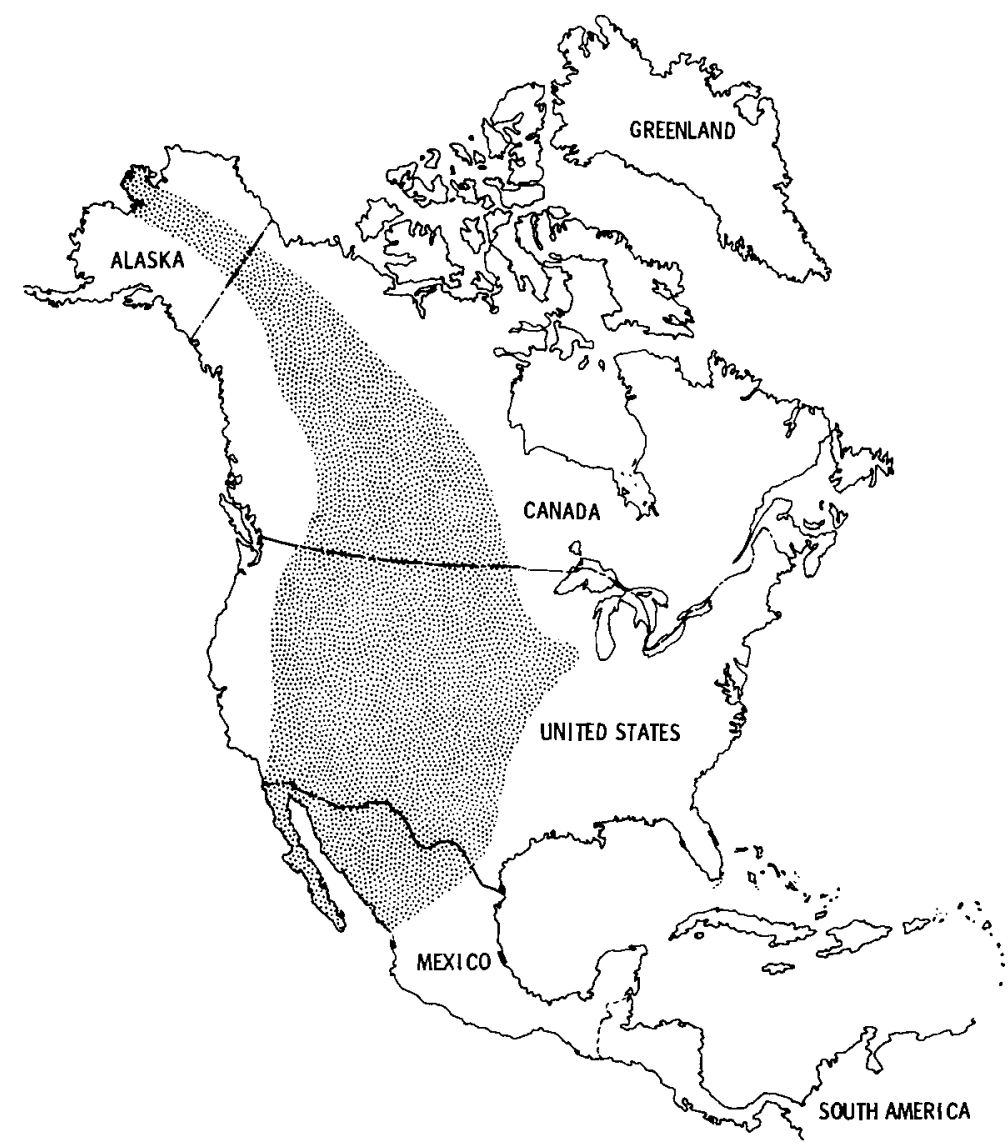

FIGURE 17. Breeding range of the Swainson's Hawk in North America.

at Hale (lat. $36^{\circ} \mathrm{S}$, long. $67^{\circ} \mathrm{W}$ ) flying east on 1 December 1975, and many more on 12 December, $10 \mathrm{~km}$ south of Hale. On 18 December 1975, he observed 1000 birds flying northwest along the Buenos Aires shore and on 30 December 1975, three birds were sighted in Combaceres (lat. $35^{\circ} 30^{\prime} \mathrm{s}$, long. $\left.67^{\circ} 10^{\prime} \mathrm{W}\right)$. About 100 Swainson's Hawks were observed roosting in a eucalyptus woods in El Triunfo de 'Orbigny, Colonel Suarez (lat. $37^{\circ} 30^{\prime} \mathrm{S}$, long. $\left.61^{\circ} 30^{\prime} \mathrm{W}\right)$ in January 1976.

One adult was observed'sitting on the ground $10 \mathrm{~km}$ south of Azul (lat. $36^{\circ} 45^{\prime} \mathrm{S}$, long. $59^{\circ} 50^{\prime} \mathrm{W}$ ) on 4 March 1976 while on 29 March 1976, one bird was observed at Azul and four in Chillar (lat. $37^{\circ} 20^{\prime} \mathrm{S}$, long. $\left.60^{\circ} \mathrm{W}\right)$. Three birds were also sighted in Alzaga (lat. $37^{\circ} 30^{\prime} \mathrm{S}$, long. $60^{\circ} \mathrm{W}$ ) and two in General Chavez (lat.' $38^{\circ} \mathrm{S}$, long. $60^{\circ} 10^{\prime} \mathrm{W}$ ).

Unknown numbers believed to be wearing red patagial wingmarkers were sighted near Herrera Vegas ( lat. $35^{\circ} 50^{\prime} \mathrm{S}$, long. $61^{\circ} 10^{\prime} \mathrm{W}$ ) during the winter of 1975-1976. These would represent birds banded as nestlings on the Hanford Site in 1975. In his field study area located about $100 \mathrm{~km}$ southwest of Buenos Aires, Fraga (1975, Ornithologist,
Buenos Aires, Argent ina, personal communication) reported no records of Swainson's Hawks since at least 1962. Apparently Swainson's Hawks were common in this area in the 1930's. The ir decline is thought to be linked with the disappearance of migratory locust in the same area. Changes in wintering distribution patterns of Swainson's Hawks in Argentina could also be the result of changing land use patterns (0lrog, 1967). Figure 18 shows present-day winter distribution of the Swainson's Hawk in South America. In comparing this distribution with a map of major vegetation zones (Fig. 19) it becomes apparent that grasslands, scrub steppe, and savannah are the dominant habitats used, with rain forest also receiving some use.

\section{MIGRATION}

The migrations of Swainson's Hawks have been labeled the most spectacular of any North American hawk (Brown and Amadon, 1968) because this species makes one of the longest migrations of any raptor nesting in North America and sometimes travels in immense flocks. Of these flocks, Skutch (1945, p. 80$)$ states, "I have never seen 


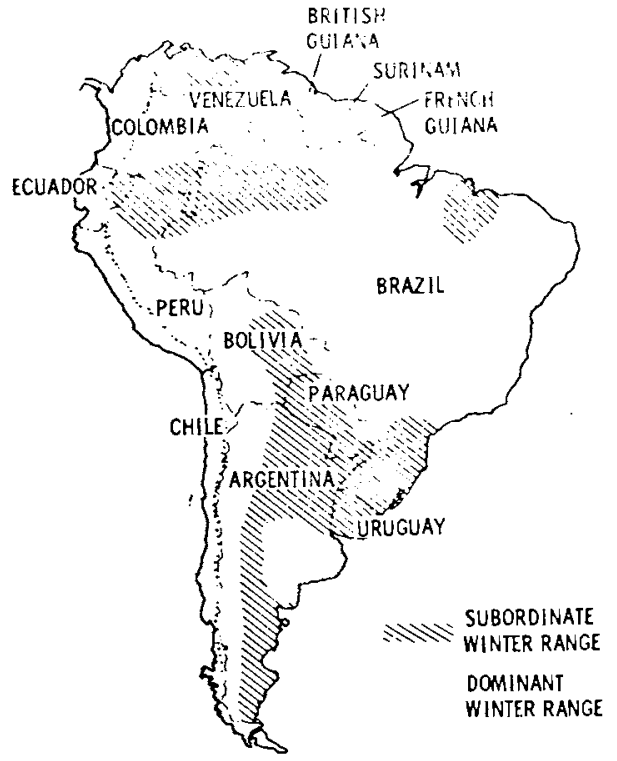

FIGURE 18. Wintering range of the Swainson's Hawk in South America.

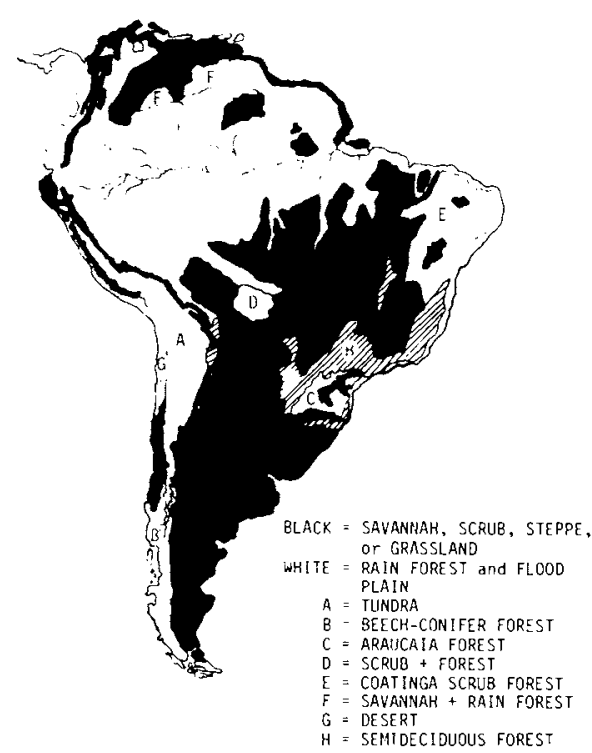

FIGURE 19. Vegetational map of South America. (Āapted from Blake, 1977)

aggregations of birds so vast as those formed by migrating Swainson's Hawks. Perhaps now that the passenger pigeon has passed into oblivion, these are the most spectacular mass movements of birds to be seen on the North American continent." From midAugust through early September, Swainson's Hawks leave their breeding grounds in North America and begin the ir migration to South America. During migration, these birds may form flocks of up to several thousand (Dawson and Bowles, 1909; Griscom, 1932; Skutch,
1945; Williams and Matteson, 1948). These large flocks, singles, and small groups move in a southwest direction.

In Mexico, the migrants have been observed in Jalisco, Guanajuato, Distrito Federal, Morelos, San Luis Potosi, Puebla, Tamaulipas, and Veracruz (Friedmann et al., 1950; Purdue et al., 1972). The sightings in Veracruz probably reflect the constricting of the Mexican land mass as it nears Central America. The hawks are here funneled into the narrows of Oaxaca and Veracruz before entering Central America.

Swainson's Hawks have been observed in northward migration in Veracruz, Mexico during late March. On 22 March 1970, an estimated 1600 hawks were observed $9 \mathrm{~km}$ west of Cardel, Veracruz during a 30 minute period. The birds were heading north-northwest. On 23 March, more hawks were observed $14 \mathrm{~km}$ south of Tamarindo and on 26 and 27 March birds were observed $22 \mathrm{~km}$ north of Vega de Alatorre, and Puente Nautla respectively (Purdue et al., 1972). Loetscher (1955) has also observed Swainson's Hawk migrations in Veracruz near Las Vigas and Jalapa. Sutton and Pettingill (1942) observed migrating Swainson's Hawks near Gomez Farias, Tamaulipas in April.

In Guatemala, Swainson's Hawks have been observed passing through chiefly in 0ctober and March to April, particularly along the Pacific slope. They pass quickly through the country and are seldom recorded (Land, 1970). Dickey and Van Rossem (1938) noted Swainson's Hawks migrating in $E l$ Salvador in the fall.

In Honduras, Swainson's Hawks have been noted in only two migrational periods, both during fall. Monroe (1968) reports that on 3 October 1953, thousands of birds were observed on the Caribbean slope between Amapa and Potrerillos. In October of 1962 , remarkable hawk migrations were observed in the San Lorenzo-Choluteca region of the Pacific slope. A flock of 50 Swainson's Hawks were noted at San Francisco on 11 october, and their numbers increased daily to a maximum of an estimated 700 birds on 13 October in the Choluteca region. During the morning of 14 October at San Francisco, the sky was black with migrating hawks. Fifty Swainson's Hawks were observed on 15 October at Choluteca. The direction of migration on the Pacific slope was west to east; the flocks crossed the continental divide to the Caribbean slope in the vicinity of San Francisco.

Skutch $(1945$, p. 88-89) states that

"Swainson's Hawks migrate in autumn down the Pacific coast of northern 
Central America, through Guatemala and doubtless also El Salvador, Honduras and Nicaragua. Then they appear to cross over to the Caribbean side, probably over the belt of lowlands that traverse the isthmus in southern Nicaragua and northern Costa Rica. A few might continue and cross the continent along the line of the Costa Rican Railroad, where the continental divide is only 5000 feet high, far lower than through most of southern Costa Rica."

Northward migrations of this species in Costa Rica have been observed mainly on the Caribbean slope. On 12 April 1936, Skutch (1945) observed an immense flock flying from east to west above the Rio Buena Vista. On 12 April 1940, beside the Rio Pacuar at the head of the Terraba Valley, two great flocks of northwestward bound Swainson's Hawks were observed. A stupendous flock was seen on 15 Apri1 1940. On 11 April 1941, a big flock of Swainson's Hawks was observed traveling at a low elevation toward the northeast in the valley of the Rio Pejivalle. On 12 April 1941, another large flock followed the same course. Migrants passed through Costa Rica on both sides of the Cordillera, apparentiy headed northward (Skutch, 1945).

In Panama, southward flights begin in the latter part of September and continue through october. The northward movement starts in early February with the main migration in March and the beginning of April. A few continue to pass through early April (Wetmore, 1965). Smith (1975, Ornithologist, University of British Columbia, Vancouver, Canada, personal communication) found them passing through the vicinity of Panama City in late October and early November. In fact, he felt that during the eariy 1970's most of the species population passed over his office on Ancon Hill. Griscom (1932) refers to a similar situation; apparently a great majority of the Swainson's Hawks in existence pass over Central America in comparatively few days, flying in a few enormous flocks which take hours to pass a given point.

The southbound migrants of ten reach Colombia as early as August but pass through chiefly in September (Brown and Amadon, 1968).

Meyer De Schauensee (1964) recorded Swainson's Hawks in Colombia from November to February in the subtropical and temperate zone of the Eastern Andes and the Cauca Valley. When in South America, the birds' journey seems more leisurely and they feed en route to the southern areas.

Swainson's hawks generally migrate in flocks, seldom mixing with other species (Skutch, 1945). Black Vultures (Skutch, 1969), Turkey Vultures (Purdue et a $7 .$, 1972), and Broad-wing Hawks (Skutch, 1945) have been observed miarating with Swainson's Hawks. Also, an immature bird marked on the Hanford Site in 1976 was seen migrating with a small group of Red-tailed Hawks at Point Diablo, Marin County, California on 7 September 1976.

The flight of the Swainson's Hawk during migration is described by Skutch (1945, p. 81).

"They try to obtain the maximum of forward movement with a minimum of muscular exertion. They journey only during the daylight, while conditions are favorable for soaring flight, and seem reluctant to make a single unnecessary wing beat. As they migrate, the big hawks regularly alternate between two distinct modes of flight, each accomplished with the wings and tail held in a characteristic manner. First they soar upward to gain altitude, then they glide forward on their way, at the same time generally losing altitude, trading it, so to speak, for forward movement. The soaring to gain altitude is generally performed above some ridge, especially one facing the sun, where there is an updraft of air. With wings spread to the fullest, the tips of the primary feathers well separated so that sky may be seen between them, and the tail half spread, the hawks gyrate round and round, gradually spiraling upwards as the ascending current lifts them with no expenditure of energy of their own. At times, all the hawks in the same great vortex will rotate in the same direction--a beautiful spectacle!-but perhaps more often there is no set direction, some individuals circling in a clockwise manner, others in the reverse direction."

"When they have gained sufficient height above the earth, the hawks leave the vortex. Now closing their wings until the forward margin is strongly convex and the joined tips of the primaries are directed backward in a single sharp point, completely folding the tail, they gi ide easily forward on their way across the sky, until they find another ascending air current, generally above another ridge, where they pause and circle once more to regain their lost altitude."

Swainson's Hawks probably do not feed during miaration (Brown and Amadon, 1968). Skutch (1945) observed that this species passes in migration without eating or drinking; however, sickly birds or those in poor ohysical condition may. On 15 April 1940, Skutch (1945) watched a flock containing 
thousands of Swainson's Hawks. They spent the night near the Rio Pacuar, Costa Rica. Some roosted on the ground, others on low stumps or logs but most of them in trees. After the birds departed the following Jay, Skutch searched the ground for castings, white droppings and eggs, but could ind no signs of their presence. Olrog (1976, Ornithologist, Instituto Miguel Lillo, Tucuman, Argentina, personal communication) collected two specimens of migrating immature Swainson's Hawks, one on 24 November 1963 and one on 23 November 1967 from flocks of 40 and 16 juvenile birds, respectively, and noted that they had empty stomachs. These flocks of hawks were also completely exhausted and could be caught by hand, which implies that the birds had probably not fed for some time. Hofslund (1973) states,

"Normal migration behavior of soaring hawks shows no regular pattern of hunting, once the flight is under way. Hunting becomes part of the pattern only when the flight is delayed by inclement weather or when the initial fat buildup is not sufficient to sustain flight for the necessary time."

As flocks of migrating Swainson's Hawks come to roost in the evening, they do not bunch. Skutch (1945, p 82) noted that they space themselves well apart, "each as a rule several feet from its neighbors." He also noted that they did not seem to have very sociable dispositions. Birds roosting in a single tree perched in different parts of it. Skutch (1945, p. 82) also mentioned that he found considerable variation in their temperaments. "Some took flight while I was still a good distance away, while other permitted a very satisfactorily close approach. All were perfectly silent."

\section{DISTRIBUTION IN WASHINGTON}

\section{Breeding Distribution}

Table 3 provides a listing of all the Swainson's Hawk study skins contained in

TABLE 3. Study Skins of Swainson's Hawks Contained in Washington Museums

\begin{tabular}{|c|c|c|c|c|}
\hline Museum & $\begin{array}{l}\text { Museum } \\
\text { Specimen } \\
\text { ilumber } \\
\end{array}$ & $\operatorname{Sex}^{d}$ & Date Collected & Location \\
\hline $\begin{array}{l}\text { Walle walla } \\
\text { College, } \\
\text { Walle walla }\end{array}$ & $\begin{array}{l}1,589 \\
2,439 \\
3,199 \\
3,201 \\
3,202 \\
3,205 \\
4,371\end{array}$ & $\begin{array}{l}\text { Male } \\
\text { Male } \\
\text { Male } \\
\text { Male } \\
\text { Immature } \\
\text { Female } \\
\text { Female }\end{array}$ & $\begin{array}{l}\text { May } 9,1945 \\
\text { Apri13,1943 } \\
\text { May } 10,1950 \\
\text { May } 13,1950 \\
\text { May } 3,1951 \\
\text { May } 12,1946 \\
\text { August } 10,1936\end{array}$ & $\begin{array}{l}16 \mathrm{~km} \text { E Moses Lake } \\
\text { wallula, Franklin Co. } \\
3 \text { W Touchet, Walla Walla Co. } \\
\text { io W College Place, Walla Co. } \\
5 \text { W College place, Walla Walla Co. } \\
5 \text { in College Place, Walla Waila Co. } \\
43 \text { S Burns, Oregon }\end{array}$ \\
\hline $\begin{array}{l}\text { Whitman College, } \\
\text { Walla Walla }\end{array}$ & $\begin{array}{l}4,262 \\
4,263\end{array}$ & $\begin{array}{l}\text { Juv. Male } \\
\text { Female }\end{array}$ & $\begin{array}{l}\text { July } 6,1922 \\
\text { May } 6,1921\end{array}$ & $\begin{array}{l}\text { near Cayton, Whitman } C o \text {. } \\
\text { near Dayton, Whitman Co. }\end{array}$ \\
\hline $\begin{array}{l}\text { University of } \\
\text { Washington, } \\
\text { Seattle }\end{array}$ & $\begin{array}{r}1,718 \\
7,672 \\
11,413 \\
17,182 \\
11,411 \\
11,414 \\
11,412 \\
11,415 \\
9,340 \\
7,673\end{array}$ & $\begin{array}{l}\text { Male } \\
\text { Male } \\
\text { Male } \\
\text { Female } \\
\text { Male } \\
\text { Female } \\
\text { Female } \\
\text { Male, inma ture } \\
\text { Unknown } \\
\text { Female }\end{array}$ & $\begin{array}{l}\text { May } 19,1934 \\
\text { Apri1 } 25,1928 \\
\text { May } 16,1934 \\
\text { May 19;1934 } \\
\text { Apri1 i3, 1937 } \\
\text { May 16, 1934 } \\
\text { May 16,1934 } \\
\text { September 24, } 1935 \\
\text { May } 1,1931 \\
\text { May } 5,1927\end{array}$ & $\begin{array}{l}\text { Neppe 1, C Grant Co. } \\
\text { Kiona, Benton Co. } \\
\text { Eltopia, Frankl in Co. } \\
\text { Neppel, Grant Co. } \\
\text { Eltopia, Frankl in Co. } \\
\text { El topia, Franklin Co. } \\
\text { El topia, Franklin Co. } \\
\text { Westport, Grays Harbour Co } \\
\text { Ritzville, Adams Co., } \\
\text { Yakima, Yakima Co. }\end{array}$ \\
\hline $\begin{array}{l}\text { University of } \\
\text { Puget Sound } \\
\text { Tacoma }\end{array}$ & $\begin{array}{l}1,046 \\
10.382 \\
\mathrm{k} 622 \\
\mathrm{k} 623 \\
\text { None } \\
16.253 \\
\mathrm{x} 621\end{array}$ & $\begin{array}{l}\text { Male } \\
\text { Male } \\
\text { Male } \\
\text { Male, Immature } \\
\text { Male } \\
\text { Female } \\
\text { Male }\end{array}$ & $\begin{array}{l}\text { September } 11,1939 \\
\text { April 15, 1946 } \\
\text { April 30, 1949 } \\
\text { September } 9,1938 \\
\text { September } 10,1937 \\
\text { September } 939\end{array}$ & $\begin{array}{l}\text { Yakima Park, Mt. Rainier National Park } \\
\text { Enterprise, Hal lawa Co. Oregon } \\
\text { kiona, Benton Co. } \\
\text { Kartar, Okanogan Co. } \\
\text { Yakima Park, Mt. Rainier National Park } \\
\text { Buttis, Yarney Co., Oregon } \\
\text { Game Farm, Steilacoom Lake, Pierce Co. }\end{array}$ \\
\hline $\begin{array}{l}\text { Washington State } \\
\text { University } \\
\text { Connor Museum } \\
\text { Pullman }\end{array}$ & $\begin{array}{l}58-277 \\
1,249 \\
699 \\
1,200 \\
52-130 \\
1,248 \\
49-467 \\
49-468 \\
59-25\end{array}$ & $\begin{array}{l}\text { Fomale } \\
\text { Fimale } \\
\text { Male } \\
\text { Female } \\
\text { Female } \\
\text { Downy Chick } \\
\text { Downy Chick } \\
\text { imma ture }\end{array}$ & $\begin{array}{l}\text { September } 28,1957 \\
\text { Apri1 12, 1332 } \\
\text { Septenber Da Avallable- } \\
\text { June 18, } 1952 \\
\text { May } 18,1930 \\
\text { June } 5,1949 \\
\text { June } 5,1949 \\
\text { September } 2,1958\end{array}$ & $\begin{array}{l}\text { 10 SE Laur, Adams Co. } \\
\text { Rock Lake, Whitman Co. } \\
16 \text { W Ritzvilie, Adams Co. } \\
21 \text { E Henry, Caribou Co.. ID } \\
\text { Ritzville, Adams io. } \\
\text { Hoover, Benton Co. } \\
\text { Hoover, Benton Co. } \\
\text { I3 E Red Rock, Lakes Refuge Headquarters, MT }\end{array}$ \\
\hline $\begin{array}{l}\text { Washington State } \\
\text { University } \\
\text { Connor Museum }\end{array}$ & $\begin{array}{l}1,247 \\
57-165 \\
48-166 \\
75-91 \\
\text { None } \\
75-90 \\
1,196 \\
621 \\
361 \\
\text { Yone }\end{array}$ & $\begin{array}{l}\text { Male } \\
\text { Female } \\
\text { Downy Chick } \\
\text { Male } \\
\text { Male } \\
\text { Female } \\
\text { Unknown } \\
\text { iale } \\
\text { Fema le } \\
\text { imnature, Fenale }\end{array}$ & $\begin{array}{l}\text { September } 10,1932 \\
\text { Apri1 } 29,1957 \\
\text { June 16, } 1948 \\
\text { July 19, } 1938 \\
\text { May } 24,1933 \\
\text { Jurie } 6,1936 \\
\text { May } 9,1930 \\
\text { Soring } 1927 \\
\text { May } 18,1936 \\
\text { August } 4,1977\end{array}$ & $\begin{array}{l}\text { Sookane, Spokane Co. } \\
5 \text { E Pullman, whitman Co. } \\
19 \text { W Ritzville, Adams Co. } \\
\text { ttkinson, Holt Co. } \\
\text { Pulliman, Whitman Co. } \\
\text { Lincoln, Lancaster Co., NB } \\
\text { Pullman, Whitman Co. } \\
\text { Pul inan, ihitman Co. } \\
\text { Pullman, Whitman Co. } \\
\text { Gould City, Gartield Co. }\end{array}$ \\
\hline
\end{tabular}

a) All birds adults unless noted otherwise.

b) Found in washington unless state is given.

(c) Neppel is former name for Moses lake. 
major Washington museums. The breeding distribution of the species (Fig. 20) was deduced from these skins, published records (Booth, 1952; King, 1953; Hudson and Yocum, 1954; Jewett et a1., 1953) and personal observations. In comparing the breeding distribution with a map of the Washington steppe region (Fig. 21), a direct relationship

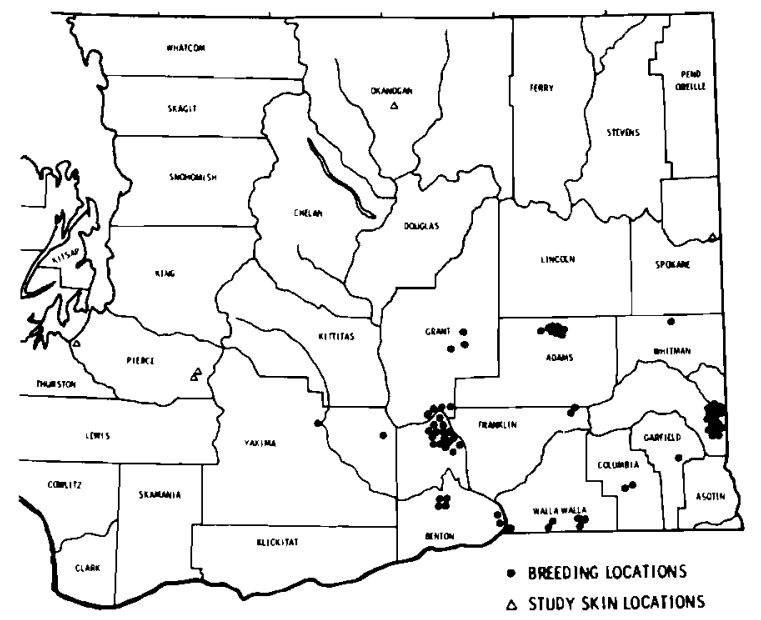

FIGURE 20. Breeding distribution of Swainson's Hawks in Washington.

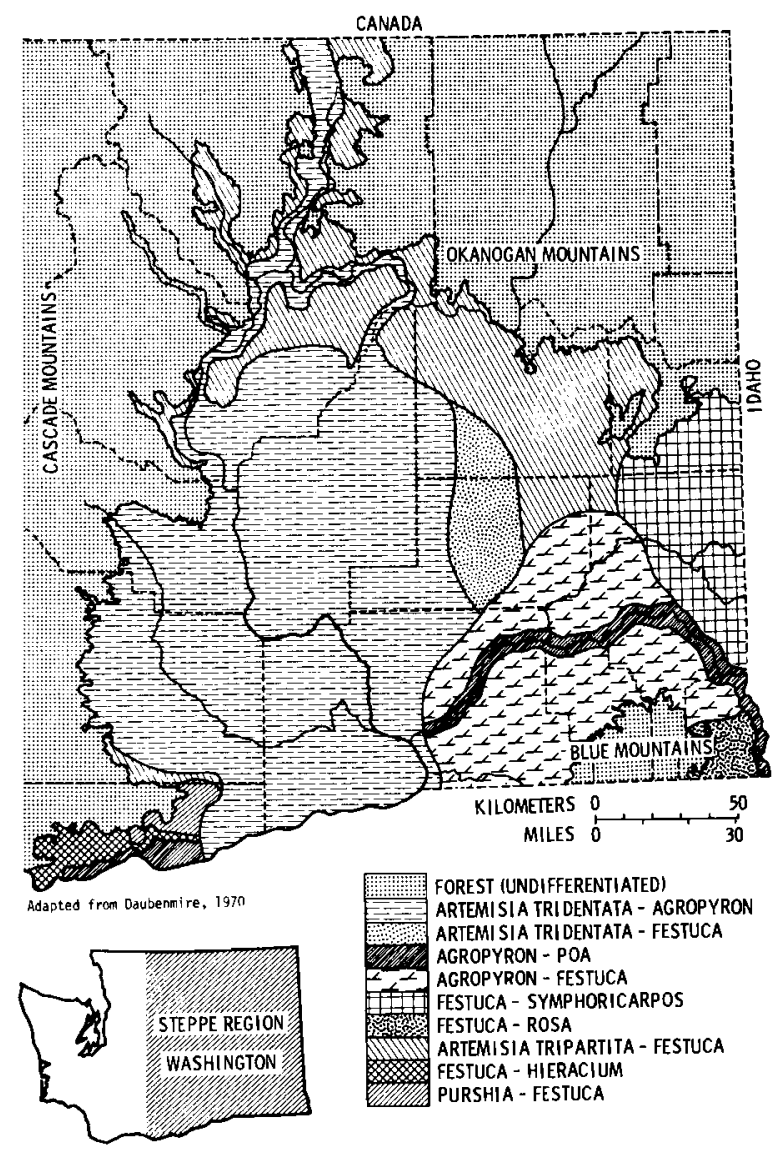

FIGURE 21. Vegetation zones of the steppe region of Washington. becomes apparent. Swainson's Hawks, like Ferrug inous Hawks, seem to nest only in the drier areas of eastern Washington. In this area, a few trees exist. Those that do are either European introductions (Black Locust, Russian 01 ive, Chinese Elm) planted by early settlers, or are species that exist naturally along rivers and streamsides (Cottonwood, Willow) or in sandy areas (Western Juniper). These trees provide the sites essential for Swainson's Hawk nesting. Trees near abandoned farmsteads and those planted for soil stabilization often have a pair of nesting Swainson's Hawks. In these situations, the birds seem to have benefited from man's past activities. Without the trees the hawks surely would not be present in much of the farm lands of southeastern Washington. During an inventory of nest sites used by Swainson's Hawks in southeastern Washington in 1975, I found only $6 \%$ of the nests were built in naturally occurring trees, while the remainder were found in trees planted by man (Table 4). It is quite probable that in precaucasian times, the Swainson's Hawk was less abundant in Washington than in modern days.

TABLE 4. Nest Sites Used by Swainson's Hawks in Southeastern Washington.

Number of Nests $\%$ of Total

$\begin{array}{lrr}\text { Black locust } & 46 & 50 \% \\ \text { Chinese Elm } & 31 & 34 \% \\ \text { Cottonwood } & 2 & 2 \% \\ \text { Power Pole } & 2 & 2 \% \\ \text { Willow } & 4 & 4 \% \\ \text { Western Juniper } & 7 & 2 \%\end{array}$

Unsubstantiated reports (Larrison and Sonneberg, 1968; Alcorn, 1971) indicate that Swainson's Hawks may also breed in the dry hot area of the 0lympic Peninsula and on San Juan Island. Since no study skins, eggs, or photographs of Swainson's Hawks could be found for these areas, there remains some doubt as to the authenticity of the reports.

Migratory Patterns of Swainson's Hawks Banded in Washington

From 1974 through 1977, I banded 83 Swainson's Hawks ( 76 nestlings and 7 adults) with U.S. Fish and Wildlife Service bands. Forty-five nestlings were also fitted with red patagial wing markers and seven adults were fitted with blue. The following are the returns to date:

1. One immature bird observed on 7 September 1976, at Point Diab10, Marin County, California. The bird was observed flying with a group of three Red-tailed Hawks. 
2. Several (precise number not available) birds marked with red, blue, and green (last color probably erroneously identified) patagial markers observed near Herrera Vegas, Argentina (lat. $35^{\circ} 50^{\prime} \mathrm{S}$; long. $61^{\circ} 10^{\prime} \mathrm{W}$ ) during the winter of 1975-1976.

3. Four immature birds found on the Hanford Site, within $3.2 \mathrm{~km}$ of the ir banding locations.

4. Five adults banded on the Hanford Site in 1976 returned to the same location in the spring of 1977.

These returns provide on ly limited information relating to migratory habits. The sighting of one immature bird on the coast of California, however, points to a possible coastal migratory route for birds nesting in southeastern Washington. Study skins of an immature male hawk collected at Grays Harbor, Washington, 24 September 1935, and an adult male collected at Steilacoom Lake, September 1939 (Table 3, Fig. 20) also lends some support to this hypothesis. Two other study skins of adult male birds collected on Mount Rainier at Yakima Park on 10 September 1937 and 11 September 1939 (Table 3, Fig. 20) provide evidence that Swainson's Hawks follow the crest or the Cascade Mountains during the ir migration or cross over the mountains to the coastal plain. Both the coastal and mountainous areas are probably used during migration, since upwellings of air masses in both areas provide wind currents necessary for the soaring flights used by Swainson's Hawks in migration (Skutch, 1945).

Radiotelemetry studies conducted on the Hanford Site in 1976 provided additional information on migratory behavior. Of 10 immature birds tagged with radiotransmitters, three were followed closely during the day of departure. All three birds began the ir migrations between 1200 and 1500 hours on warm, sunny days. One young bird from nest 10 left on Auqust 27 and headed southeast following the Columbia River toward Wallula. This individual bird was not tracked beyond that point. On 8 September two young from nest 19 began their migration. Both left between 1400 and 1500 hours. They were observed soaring at 1200 hours over the nesting territory and eventually the ir soaring progressed southwestward over the Horse Heaven Hills in southern Benton County, Washington. On the following morning at sunrise, a single engine Cessna 182 was outfitted with a 4-element Yagi antenna and receiver and the young hawks were sought. One young was tracked to a spot characterized as a dry-land wheat farming area, $45 \mathrm{~km}$ southwest of its nest. It could not be 10cated on 10 September. The second bird could not be found within a $100 \mathrm{~km}$ radius of its nest the morning before. It evidentlv had flown beyond this range the preceding day.

In late August and early September, Swainson's Hawks leave Washington on their southward migration. The earliest date of departure for 15 immature hawks studied in 1976 was 27 August and the latest date was 8 September. The latest date I have for a Swainson's Hawk in southeastern Washington was 27 September 1975. This bird was an adult male at nest 3 . Other late records in Washington are on 28 September 1957, in Adams County, Washington, 24 September 1935, at Grays Harbor, Washington (Table 3, Fig. 20), and 16 October 1915 (Dice, 1918).

\section{NESTING CHRONOLOGY}

The Swainson's Hawk is one of the latest nesting species of hawks in North America. In southeastern Washington, it arrives on its breeding grounds during early April. The earliest arrival record for the Hanford Site was 7 April 1976. Most territories on the Hanford Site are occupied by 20 April and 1 May. The majority of the nest sites on the Hanford Site from 1975 to 1977 were filled between 18 and 25 April. Figure 22 shows the nesting chronology of the Swainson's Hawk on the Hanford Site for years 1975 through 1977.

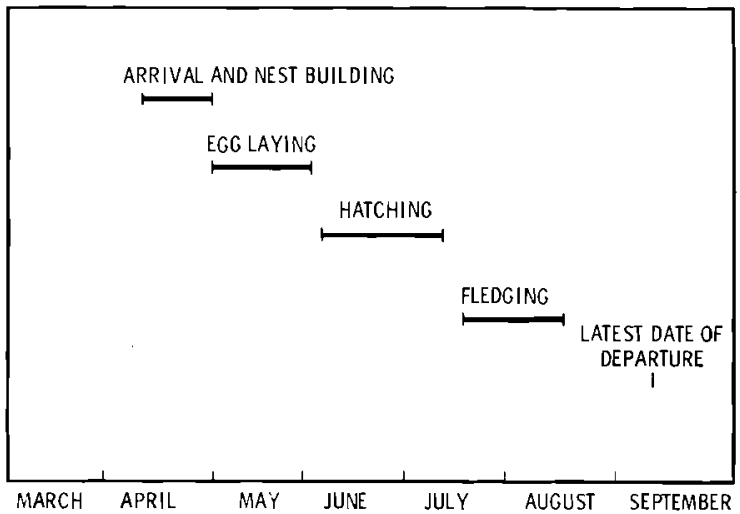

FIGURE 22. Nesting chronology of Swainson's Hawks in southeastern Washington.

The earliest recorded date for eqg laying on the Hanford Site was 28 April 1976, with most egg laying occurring between 12 through 16 May.

The earliest recorded date for hatching on the Hanford Site was 1 June 1975. Most hatching (1975-77) occurred between 14 and 19 June, and the latest data recorded was 5 July. 
The earliest recorded date of fledging was 15 July 1975. The average date of fledgina was between 25 July and 5 August (1975-77), and the latest date was 15 August 1975 .

Swainson's Hawks began to migrate from the Hanford Site in late August and early September and most were gone by 5 September. The latest date I observed Swainson's Hawks on the Hanford Site was 27 September 1975.

\section{COURTSHIP}

The courtship display of the Swainson's Hawk is a vigorous acrobatic flight. As with other Buteos, the male does most of the performing (Fitch et al., 1946; Brown and Amadon, 1968; Hubbard, 1974).

On three separate occasions, I observed courtship flights by the Swainson's Hawk. On 16 April 1975, a pair was observed soaring on the Hanford Site at nest site 6 . Both birds soared (400-500 m diameter circle, $80-150 \mathrm{~m}$ in altitude) together over a tree containing a nest. The flight was a typical spread wing and tail soar with little flapping. When directly over the nest, the smallest bird (I assume the male) broke out of the soar and began a long descending glide toward the southeast. During the glide when at elevation of about $50 \mathrm{~m}$, the bird suddenly began a rapid, flapping flight, followed shortly by a closure of wings and a 15 to $30 \mathrm{~m}$ nearly vertical stoop. At the bottom of the stoop, he opened his wings halfway and arced upwards. After accomplishing this recovery of the downward dive, the wings were held against the bird's body and the momentum gained from the downward flight served to propel him upward. The upward flight was launched as a follow-through of the dive, not from a horizontal flight or tight circle as noted by 0lendorff (1974). During upward flight, the bird's body was held in a near-vertical position, and as $h$ is momentum decreased, he had to flap his wings to regain his original altitude. The bird leveled off and began a rapid beating of wings. This again was shortly followed by another stoop, recovery and ascent. This same pattern was followed until five separate dives had been made. At the end of this acrobatic display, the bird began a short dive to a dead tree located less than $50 \mathrm{~m}$ from the nest. This tree was the spot where copulation was frequently observed.

Between the beginning of the rapid flapping flight and arrival at the dead tree, approximately 50 seconds elapsed. During this time the female remained soaring. She did not land next to the male until about five minutes after the display. No copulation, posturing, or vocalization took place after the display.
On 4 May 1976 and 10 June 1976, at nest site 17 on the Hanford Site, courtship flights were again observed. Both of these flights were only segments of that observed in 1975. On 4 May, I observed the larger bird of the pair perched in a dead tree $100 \mathrm{~m}$ from the nest. The smaller bird (I assume the male) then flew in front of the observation blind, heading due west away from the female. He turned after flying about $200 \mathrm{~m}$ from the female and started back towards her. He began a rapid wing-beating followed by a closed wing descent. A descent of about $10 \mathrm{~m}$ was followed by a partially open-winged recovery and a closedwing partial ascent, followed by wing flapping to gain original altitude. The bird's ascent leveled off at about $30 \mathrm{~m}$ and the hawk began the rapid wing-beating. This rapid flying-diving-recovery-ascent occurred three times and was followed by the male landing next to the female. Again, no copulation, posturing, or vocalization was noted.

On June 10 at nest site 17, I was observing the female preening on a fence post within $20 \mathrm{~m}$ of the nest. After preening for nearly 30 minutes, she flew off. The male then called (keeeeooo keeeeooo) from his perch in the nest tree and flew off toward the west. He reached an altitude of about $50 \mathrm{~m}$ and then soared over the nest for a few seconds. Suddenly, the bird folded his wings and descended sharply, recovering within $30 \mathrm{~m}$ of the ground. He did not use the momentum of the dive to propel himself skyward; rather, he flapped vigorously in an upward path until he reached a height of about $100 \mathrm{~m}$ when he again resumed soaring. While soaring about, he called several times (keeeeooo keeeeooo).

The female soared above the male at about $200 \mathrm{~m}$ during the entire display. A third Swainson's Hawk was observed flying high above at an elevation of over $500 \mathrm{~m}$. That bird (sex unknown) shortly flew off and the female Swainson's Hawk landed in the nest tree and perched next to the nest momentarily. She flew off, made a tight circle around the nest tree and lighted in the nest where she remained for over 30 minutes. The male had flown off after his display and did not return for over 30 minutes.

Olendorff (1974) in the only published report on the courtship display of the Swainson's Hawk stated "after the dive the bird continued a vigorous, flapping flight in a circular path (perhaps $25 \mathrm{ft}$ in diameter), climbed sharply a few feet, stalled and dove again." My observations differ somewhat from his in the method of recovery of the male hawk after the dive.

From my observations the courtship behavior does not appear sterotyped and I 
believe variations in pattern exist among birds. The stooping or diving behavior appears to be an important part of the courtship display for the Swainson's Hawk, other Buteos, and other genera of raptors as we 11. Such behavior has been reported for Swainson's Hawks (0lendorff, 1974), Redtailed Hawks (Fitch et al., 1946; Austing, 1964), other Buteos (Brown and Amadon, 1968), Swallow-tailed Kites (Snyder, 1974), Golden Eagles (Brown and Amadon, 1968), Peregrine Falcons (Cade, 1960), and a number of other hawks (Brown and Amadon, 1968).

\section{COPULATION}

Copulations generally took place early in the day, with the first copulation occurring within 15 to 30 minutes after the first light of morning. Copulations continued irregularly during the first ? or 3 hours in the morning. Copulations were also recorded for evening periods (within 2 hours of sundown) but were less frequent than morning copulations. During several full days of observation in 1976, the following was recorded:

1. 30 April 1976--recorded copulations at $0610,0648,0730,0743,0758,0819$, and 1843 hours.

2. 1 May 1976--recorded copulations at $0625,0720,0813,1843,1900$, and 1943 hours.

3. 5 May 1976--recorded copulations at $0614,0650,0725,0755$, and 0830 hours.

4. 7 May 1976--recorded copulations at $0531,0612,0657,0720,0811$, and 1800 hours.

Data on copulations gathered during partial days of observations supported these findings.

Copulatory behavior as observed in two different pairs held the same general pattern. The female, perching usually on a horizontal dead limb, would sit quietly as the male flew in from another perch. As the male neared, the female assumed a solicitation posture. This posture (Fig. 23) was characterized by a squatting position on the limb, outstretched neck, usually downwardly tilted head, lowered wings, and tail raised nearly vertically. The male then landed directly up on her back, resting on his tarsi while keeping his toes in a fist. With outstretched wings lightly fluttering, he then balanced and adjusted his position from a horizontal to slightly raised position (Fig. 24). This adjustment seldom lasted over 2 or 3 seconds. For the next 2 to 7 seconds, while still balancing on the

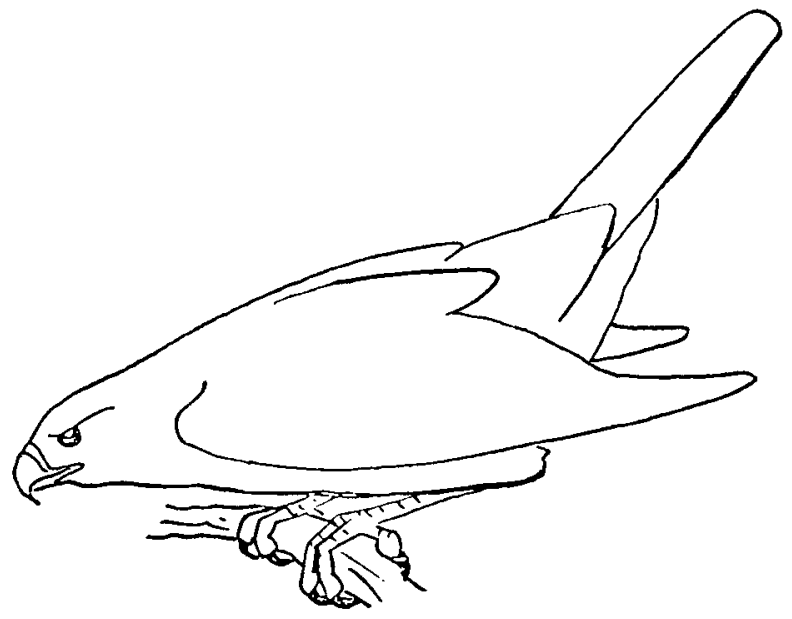

FIGURE 23. Female solicitation posture (sketch by author).

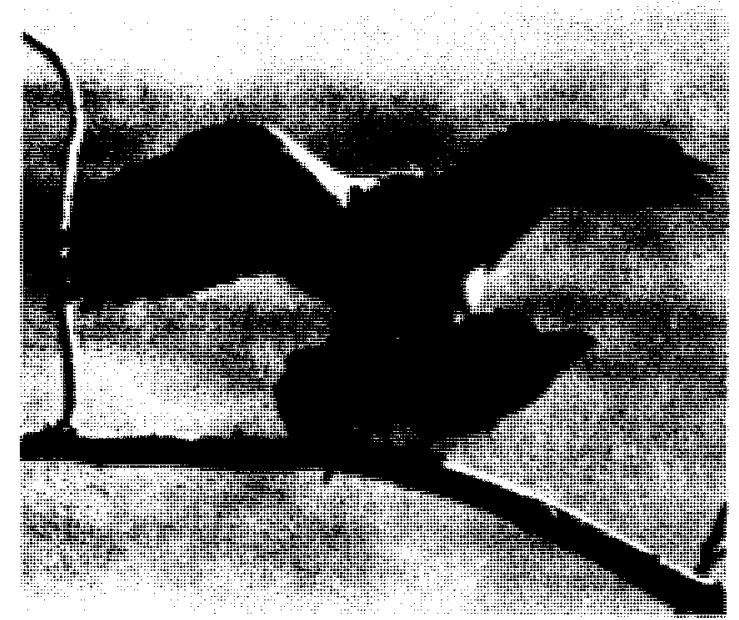

FIGURE 24. Swainson's Hawks copulating.

female's back, the male brought his partially fanned tail under the female's and bent his head downward toward the neck of the female. Seldom did he touch $h$ is beak to her feathers. After copulation, the male dismounted and would generally sit adjacent to the female. The pair of ten remained perched together for the next hour or so and would copulate whenever the female solicited. Between copulations, the birds would usually conduct a meticulous preening of their feathers. Post-copulatory activities also included nest building, hunting, soaring, and harassment of other species of raptors.

During copulation, one of the pair uttered a soft one-syllable call (weeeee----), which resembled the food call of the very 
young Swainson's Hawk. I was not able to determine which bird of the pair produced the call but speculate it was the female, because the female Red-tailed Hawk has been known to solicit copulation while giving the begging call of the young (Fitch et al., 1946).

The duration of mounting and copulation for two pairs of birds was measured on over 50 occasions and ranged from 4 to $22 \mathrm{sec}-$ onds, with a mean of 7.2. The shorter periods of mounting may not have resulted in successful sperm transfer, but in these instances, the sequence of events from balancing to tail lowering by the male was the same as in the longer copulations. Snyder (1974) noted that copulations in Swallowtailed Kites averaged 31.6 seconds, ranging from 28 to 37 seconds. Most of this period was taken up by the balancing adjustment by the male. The anatomical variations between the two species may strongly affect the duration of mounting and copulation.

Copulations were observed mostly during the nest-building period. Two different pairs of birds at nest sites 1 and 17 were observed copulating in late June during incubation. In both instances, an intruder was present. On 15 June 1976, I was approaching nest site 1 , and both adults had screamed at me while soaring overhead. The adults flew off shortly to a nearby wooden power pole and perched on a crossarm. The male, without the female's solicitation, then flew to the female's back, mounted her, and proceeded to copulate. I am not certain whether the copulation was complete, since it only lasted four seconds.

On 20 June at nest site 17, an adult Redtailed Hawk soared low over the Swainson's Hawk nest. The female Swainson's Hawk was perched on a limb of the nest tree and did not take flight. The male Swainson's Hawk, perched on the limb of a dead tree some $100 \mathrm{~m}$ from the nest tree, flew to the female, mounted her and appeared to copulate. The entire sequence again lasted on ly a few seconds.
NESTING

\section{NEST SITE SELECTION AND CHARACTERISTICS}

From 1971 through 1977, data were recorded for 92 nests. Ninety nests were constructed in trees and two in crossarms of wooden utility poles (Table 4 ).

Plant community types used for nesting in southeastern washington in 1975 and the number and fate of the 43 nests associated with them are given in Table 5. The broken grasslands community is best described as abandoned farmlands which were once tilled but are now deserted and have been invaded by Cheatgrass. The Hanford Site and the Saddle Mountain area are largely made up of this community. Trees planted during the early 1900 's for shade or fruit abound in the Cheatgrass community and provide nesting sites for Swainson's Hawks. The cultivated lands are located in the Pullman/Colfax, Kahlotus/Washtucna, and Benton City areas. Cereal grains and peas are dominant crops in the Pullman/Colfax area. Small groves or single trees (primarily Black Locust) serve as nest sites. The desert-shrub land is characterized as having a dominant overstory of perennial shrubs (Big Sagebrush, Antelope Bitterbrush, Hopsage, Greasewood). Big Sagebrush is the dominant shrub in this community. The understory vegetation consists of grasses (perennial bunchgrasses and Cheatgrass) and forbs.

The unbroken juniper grassland comunity is primarily grazing land which has a ground cover of Cheatgrass and native perennial bunchgrasses. Big Sagebrush, Antelope Bitterbrush, and Rabbitbrush are more or less evenly distributed throughout this community. Junipers are present and occur as scattered clumps (savannahs) or as individuals (Fitzner et al., 1977). these trees provide sites for nesting.

The broken grasslands and unbroken juniper grasslands had nesting successes of 73 and $86 \%$ respectively while the unbroken

TABLE 5. Number and Fate of Nests Associated with Dominant Habitat Types Observed in Southeastern Washington

\begin{tabular}{|c|c|c|c|c|c|}
\hline $\begin{array}{l}\text { Nests, } \\
1975\end{array}$ & $\begin{array}{c}\text { Number } \\
\text { of } \\
\text { Nests } \\
\end{array}$ & $\begin{array}{l}\text { Unbroken } \\
\text { Grass land }\end{array}$ & $\begin{array}{c}\text { Broken } \\
\text { Grassland }\end{array}$ & $\begin{array}{c}\text { Unbroken } \\
\text { Juniper } \\
\text { Grassland } \\
\end{array}$ & $\begin{array}{c}\text { Cultivated } \\
\text { Land } \\
\end{array}$ \\
\hline Nests with Eggs & 37 & 7 & 13 & 7 & 10 \\
\hline $\begin{array}{l}\text { Nests Fledging } \\
\text { Young }\end{array}$ & 29 & 4 & 11 & 6 & 8 \\
\hline Total Nests & 43 & 7 & 15 & 7 & 14 \\
\hline
\end{tabular}


grassland and cultivated land nest sites each had $57 \%$ nesting successes. These differences in nesting successes are probably related to other factors than habitat alone. Human interference, no doubt, also is a factor. The unbroken juniper grassland and broken grassland habitats were infrequently used by man while the cultivated lands were used more often. The low success rate of nests in unbroken grassland habitats is unexplained. Perhaps the prey base in this situation is less varied than in other habitats. The unbroken grasslands are successionally more advanced than the other habitat types, and generally are large tracts of fairly homogeneous vegetation. The other habitat types had been disturbed either by past cultivation or grazing. They were less successionally advanced and vegetation types were fairly heterogeneously arranged. This situation resulted in somewhat of an edge effect (Odum, 1963), possibly promoting diversity in prey species and thereby providing a better prey supply than the unbroken grasslands.

Swainson's Hawks may construct fresh nests or may build upon nests previously constructed by other birds. Of 59 nests with known construction histories, $51 \%$ were built fresh and $49 \%$ were built upon abandoned nests. The old nests utilized for refurbishment had previously been used by Swainson's Hawks (74\%), Magpies (18\%), Crows (3\%), Ravens (3\%) and Red-tailed Hawks (3\%). Nine \% of the nests built from scratch were unsuccessful in fledging young, while $8 \%$ of the refurbished nests were unsuccessfut. Apparently the utilization of old nests had no effect upon the fledging potential of a nest site.

Swainson's Hawk nests in southeastern Washington were 2.1 to $73.1 \mathrm{~m}$ above ground. of 57 recorded nest heights, the mean was $5.6+$ S.E. $0.34 \mathrm{~m}$. Measurements of nest diameter, nest depth, nest bowl diameter, and nest bowl depth were recorded from a sample of 18 nests during 1977 that were freshly built where incubation had not begun or was in its initial stages. Nest diameters ranged from 60 to $97 \mathrm{~cm}$ ( $x=$ $73.9 \pm$ S.E. 3.61$)$ and height ranged from 18 to $74 \mathrm{~cm}(37.0 \pm$ S.E. 4.46). Nest bow 1 diameters ranged from 22.8 to $23.8 \mathrm{~cm}$ (23.1 \pm S.E. 0.08); nest bowl depths ranged from 7 to $11.6 \mathrm{~cm}(8.5 \pm$ S.E. 0.34$)$.

Twenty-nine (49\%) of 59 nests with known construction histories were situated in the main fork of the nest tree, with 28 (47\%) of these placed on side branches and two (2\%) against the main trunk.

\section{NEST CONSTRUCTION}

Nest construction begins usually within 7 to 15 days after Swainson's Hawks arrive at their territories. The majority of Swainson's Hawk pairs beg in construction by the end of April or first week in May. Nest building lasts about one week, occasionally taking up to two weeks. Most of the nest building occurs generally during the first four hours of daylight.

Males make about twice as many trips to the nest with nesting materials as do the females (Table 6) and also do more of the arranging of these materials. On six separate occasions I observed the male at nest 17 receiving nesting material from the female while he was standing on the nest and he positioned it while she flew off to gather more. This male was also observed shaping the nest bowl. He accomplished this by pulling at sticks with his beak and then sitting in the bowl quivering slightly as if fashioning the bowl to his body contours. The female was also observed performing the same motions.

TABLE 6. Materials Observed Being Carried to Two Nests Under Construction in 1976

\begin{tabular}{lcc}
\multicolumn{1}{c}{ Materials } & $\begin{array}{c}\text { Males Visits } \\
\text { dead tree branches }\end{array}$ & $\begin{array}{c}\text { Females } \\
\text { Sis Visits }\end{array}$ \\
$\begin{array}{l}\text { Iiving tree branches } \\
\text { with attached leaves }\end{array}$ & $18(56 \%)$ & $20(53 \%)$ \\
$\begin{array}{l}\text { Russian thistle } \\
\text { branches }\end{array}$ & $4(6 \%)$ & $4(11 \%)$ \\
$\begin{array}{l}\text { jim Hill mustard } \\
\text { plants }\end{array}$ & $8(12 \%)$ & $10(26 \%)$ \\
\hline
\end{tabular}

The nest materials used to construct the two nests were dead branches of Cottonwood (Populus sp.), live limbs from the same trees and pieces of two summer annual forbs, Russian Thistle (Salsola kali) and Jim Hill Mustard. The reasons for the fewer number of observed visits by the females and selection of fewer limbs and more Jim Hill Mustard are unclear at present, but I can offer an hypothesis. A female, prior to egg laying, may be conserving energy for egg production. Trips with nesting materials would use precious energy, particularly if the female had to fly far to find the materials or if she had to work hard in securing them. The 
living limbs undoubtedly took most energy to gather since they had to be broken from a tree and carried back to the nest; Jim Hill Mustard plants were dead and easily plucked from the ground. Their abundance and light weight provided for short flights with little weight, while living limbs required longer flights with heavier material.

Both parents brought fresh sprigs of trees to the nests before and after hatching. Sprigs were broken from the outer and top limbs of the tree. Cottonwoods, Chinese $\mathrm{Elm}$, and Black Locust were the common tree species used on the Hanford Site. In the Colfax/Pullman area, sprigs of Black Locust were most connnonly used while Western Junipers were most common in the Juniper area of southern Franklin County. Apparently the selection of fresh greenery was dictated primarily by the relative abundance of the tree species present.

\section{EGG LAYING}

\section{CLUTCH INITIATION AND RATE OF EGG-LAYING}

Swainson's Hawks generally laid their first egg within 7 to 14 days after arrival at the ir nesting grounds. In most instances, eggs were laid in the morning.

Precise intervals in hours and minutes were not recorded for elapsed time between successive eggs, but field observations indicated that about two days (40-48 hours) elapse between egg deposition (Table 7). Brown and Amadon (1963) indicated that birds of prey deposited eggs at intervals of more than one day, usidally two or three and sometimes more.

TABLE 7. Egg Deposition Rate in Swainson's Hawks on the Hanford Site - 1977

\begin{tabular}{|c|c|c|c|}
\hline $\begin{array}{l}\text { Nest } \\
\text { No. }\end{array}$ & $\begin{array}{l}\text { Egg } \\
\text { No. }\end{array}$ & $\begin{array}{c}\text { Date Egg } \\
\text { Laid } \\
\end{array}$ & $\begin{array}{c}\text { Approximate Time } \\
\text { Since Deposition } \\
\text { of Preceeding Egg } \\
\text { hr }\end{array}$ \\
\hline 2 & $\begin{array}{l}1 \\
2 \\
3\end{array}$ & $\begin{array}{r}9 \text { May } \\
11 \text { May } \\
13 \text { May }\end{array}$ & $\begin{array}{l}46 \\
45\end{array}$ \\
\hline$\sigma$ & $\begin{array}{l}1 \\
2 \\
3\end{array}$ & $\begin{array}{l}30 \text { Apri1 } \\
\text { ? May } \\
4 \text { May }\end{array}$ & $\begin{array}{l}46 \\
47\end{array}$ \\
\hline 20 & $\begin{array}{l}1 \\
2 \\
3 \\
4\end{array}$ & $\begin{aligned} 30 & \text { Apri } 1 \\
2 & \text { May } \\
4 & \text { May } \\
6 & \text { May }\end{aligned}$ & $\begin{array}{l}47 \\
45 \\
43\end{array}$ \\
\hline
\end{tabular}

\section{CLUTCH SIZE}

Swainson's Hawks lay from one to four eggs (Bent, 1961; Brown and Amadon, 1968), with two being the most common clutch size in southeastern Washington. Criddle (1915) found one nest containing five eggs from which four young hatched and another nest containing seven eggs from which five young hatched. Although he reported these to be Swainson's Hawks, large clutches are not typical of the Swainson's Hawk. The nest which Criddle claimed to contain seven eggs was located on the ground, and was bulky, being built of large sticks and having a bark lining which describes the nest of the Ferrug inous Hawk (Weston, 1969; Fitzner et al., 1977). However, Criddle observed these large clutches in early June which would be a late date for finding Ferruginous Hawk clutches.

\section{INCUBATION STAGE}

\section{ADULT BEHAVIOR}

In the four nests intensively studied with time-lapse photography during incubation, the female hawks stayed in the nest. The male provided food for the female. slight variations in the male's attentiveness to tine nest were observed, however.

The males usually visited the nests when bringing food to the females. Their visits were short, lasting from 5 to 30 minutes. However, on one occasion, a male at nest 17 was observed sitting on a nest for 3 hours. This same male of ten sat beside the female as she incubated the eggs. No other males were recorded behaving in this way. In the transfer of food, the female usually flew to intercept the prey from her mate. Infrequently, the male would alight in the nest tree or on the nest, where he would transfer the food. The female would fly off to a distant perch to consume the food. "During her leave the male would attend the nest. He assumed the same nesting posture of the female but kept a lower profile on the nest. Incubating females usually sat with their heads up, always alert, while the males often sat with their heads resting on the nest. The male stayed on or adjacent to the nest until the female returned. Females generally returned to the nest within 10 minutes, but 30 minute leaves were not uncormmon.

Periods of female absence were not all associated with feeding. Preening, collection of nesting material, and defecation were also observed activities. I did not observe defecation from the nest by either male or female. Most observed defecations 
were made from perches (trees, power poles, fence posts) located over $100 \mathrm{~m}$ from the nests.

The females' attentive periods ranged from a few.minutes to hours at a time. Inclement weather or excessively hot sunny days kept her on the eggs almost continuously. During the attentive period, females of ten changed position on their nests and occasionally placed the ir beaks down into the nest cup, apparently to turn the eggs. Matray (1974) noted this behavior in Broad-winged Hawks (Buteo platypterus). Females standing on the nest rim to preen or stretch were also frequently observed. Nocturnal incubation was probably done solely by the female. Direct observations from blinds always revealed the female to be present on the nest at sunrise and again present at sunset. It is unlikely that the male alternated positions with her during the night, since he generally roosted away from the nest tree.

\section{DURATION OF INCUBATION}

Brown and Amadon (1968) and Bent (1961) report the incubation period for the Swainson's Hawk to be 28 days, and 0 lendorff (1973a) report it to be 35 days. During 1977, three nests were closely watched to determine the incubation period of Swainson's Hawks in southeastern Washington. Table 8 provides a detailed chronology of 10 eggs.

\section{NESTLING PERIOD}

\section{ADULT BEHAVIOR}

\section{Attentiveness}

During the nesting period, the female attends to the young at the nest site, while the male's duties revolve around food gathering for his mate and the young. Of three nests (1,3, and 4) where time-lapse cameras were used to record time budget information, males were seldom observed attending to the young. Figures 25 and 26 show the percentage of daylight hours each adult spent at the nest proper and indicate that males spent much less time at the nests than females. The males at nests 1 and 4 were recorded attending to the young on several occasions. During these periods the males were primarily engaged in shading the young birds from excessive solar radiation on hot, sunny days. Males at all three nests were also recorded feeding the young. Female attentiveness consisted of feeding, brooding, and shading.

\section{Brooding}

During the nestling period, females at nests 1,3 and 4 brooded nestlings during daylight hours for about nine days (Fig. 27). During the first day or two after hatching, females brooded the young

TABLE 8. Chronology of Egg Development in the Swainson's Hawk - 1977

\begin{tabular}{|c|c|c|c|c|c|c|}
\hline Nest No. & Egg No. & $\begin{array}{l}\text { Date Egg } \\
\text { Laid } \\
\end{array}$ & $\begin{array}{c}\text { Date Egg } \\
\text { First Pipped } \\
\end{array}$ & $\begin{array}{c}\text { No. Days from } \\
\text { Laying to Pipping }\end{array}$ & $\begin{array}{l}\text { Date } \\
\text { Hatched }\end{array}$ & $\begin{array}{l}\text { No. Days } \\
\text { from Laying } \\
\text { to Hatching }\end{array}$ \\
\hline 2 & $\begin{array}{l}1 \\
2 \\
3\end{array}$ & $\begin{array}{r}9 \text { May } \\
11 \text { May } \\
13 \text { May }\end{array}$ & $\begin{array}{l}12 \text { June } \\
13 \text { June } \\
13 \text { June }\end{array}$ & $\begin{array}{l}35 \\
34 \\
32\end{array}$ & $\begin{array}{l}13 \text { June } \\
13 \text { June } \\
14 \text { June }\end{array}$ & $\begin{array}{l}36 \\
34 \\
33\end{array}$ \\
\hline 6 & $\begin{array}{l}1 \\
2 \\
3\end{array}$ & $\begin{aligned} & 30 \text { April } \\
& 2 \text { May } \\
& 4 \text { May }\end{aligned}$ & $\begin{array}{l}3 \text { June } \\
3 \text { June } \\
6 \text { June }\end{array}$ & $\begin{array}{l}35 \\
33 \\
34\end{array}$ & $\begin{array}{l}4 \text { June } \\
5 \text { June } \\
7 \text { June }\end{array}$ & $\begin{array}{l}36 \\
35 \\
35\end{array}$ \\
\hline \multirow[t]{2}{*}{20} & $\begin{array}{l}1 \\
2 \\
3 \\
4\end{array}$ & 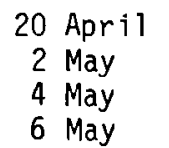 & $\begin{array}{l}3 \text { June } \\
3 \text { June } \\
4 \text { June } \\
5 \text { June }\end{array}$ & $\begin{array}{l}35 \\
33 \\
32 \\
31\end{array}$ & $\begin{array}{l}4 \text { June } \\
4 \text { June } \\
5 \text { June } \\
7 \text { June }\end{array}$ & $\begin{array}{l}36 \\
34 \\
33 \\
33\end{array}$ \\
\hline & & & & $=33.4 \pm$ S.E. 0.42 & $\bar{x}$ & $4.5 \pm$ S.E. \\
\hline
\end{tabular}

The incubation period ranged from 33 to 36 days. This period falls within the 30-38 day interval typical of most Buteos (0 lendorff, 1971). almost continuously ( $70.3 \%$ attentive). The females brooded with decreasing frequency during the following seven days. As frequency of brooding dropped off, shading 


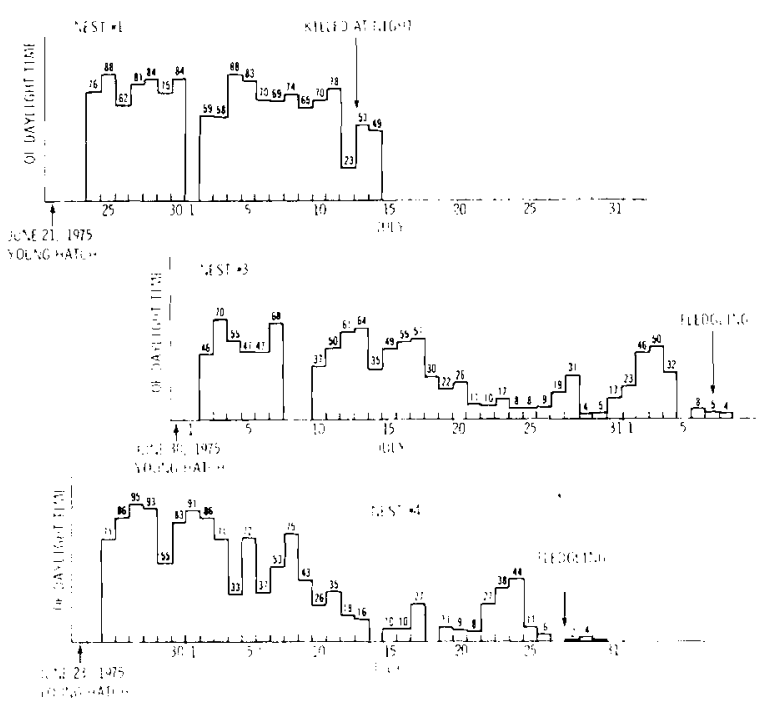

FIGURE 25. Nest attentiveness of female Swainson's Hawks during the nestling stage.

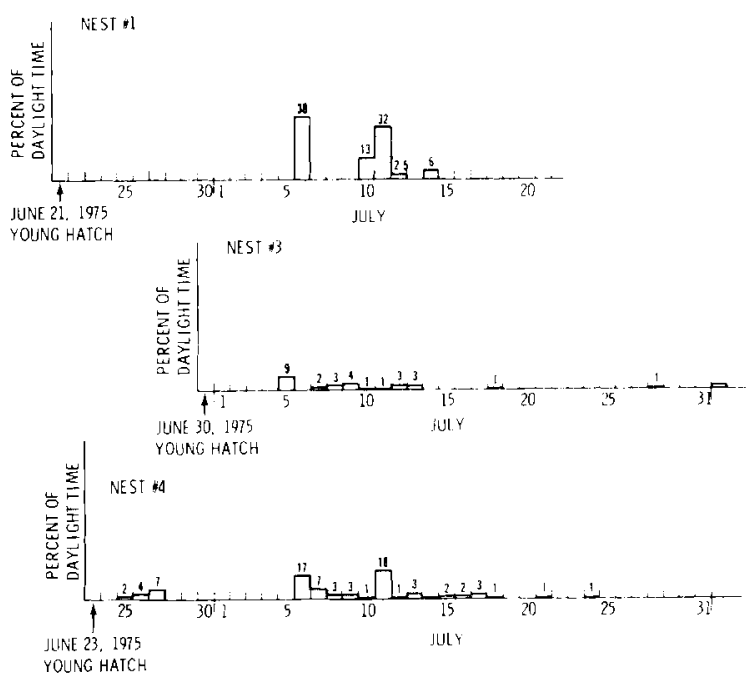

FIGURE 26. Nest attentiveness of male Swainson's Hawks during the nestling stage.

increased. The presence of the female on the nest at dusk and dawn indicated that the young were brooded through the night unti? 17-22 days of age. Matray (1974) found that Broad-winged Hawks brooded at night until young were 21-24 days old.

Shading

Shading was done mostly by the female, but males participated on occasion. Most of the male attentiveness exceeding $5 \%$ on a daily basis can be attributed to shading. Shading behavior (Fig. 28) appeared to be

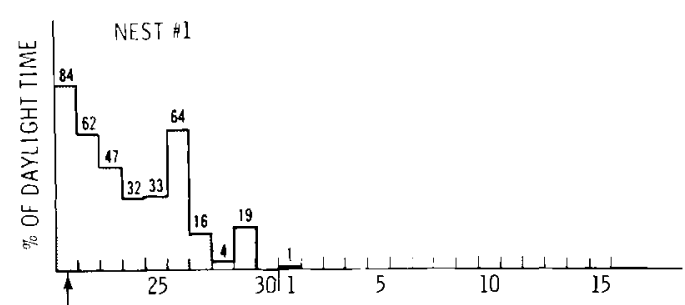

JUNE 21, 1975 YOUNG HATCH

$J U L Y$

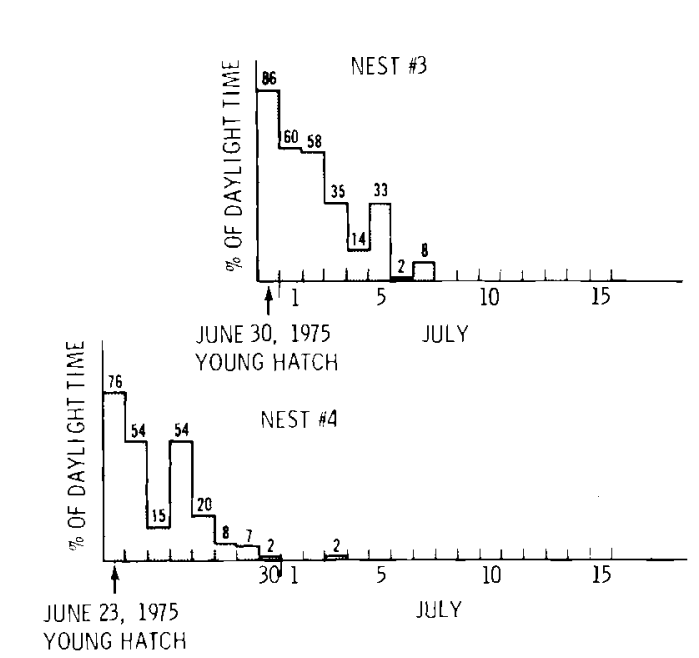

FIGURE 27. Frequency of brooding of nestlings by female Swainson's Hawks during daylight.

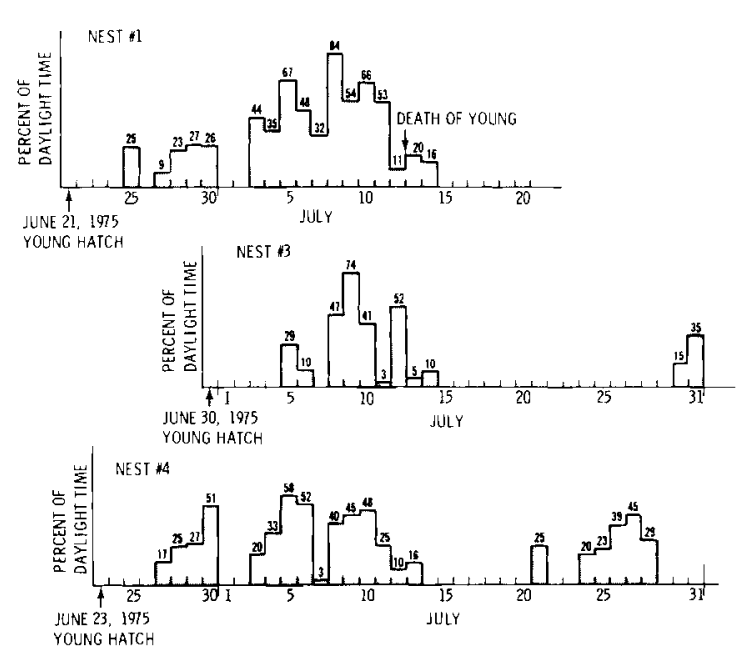

FIGURE 28. Frequency of shading of nestlings by female Swainson's Hawks during daylight. 
most prevalent on the hottest, sunniest days, particularly during the early life of the young. This behavior, no doubt, aided the young birds in thermoregulation during stressful periods. Figure 29 shows the female at nest site 4 shading three young. The fanned tail and half spread, dropped wing posture was characteristic of shading behavior.

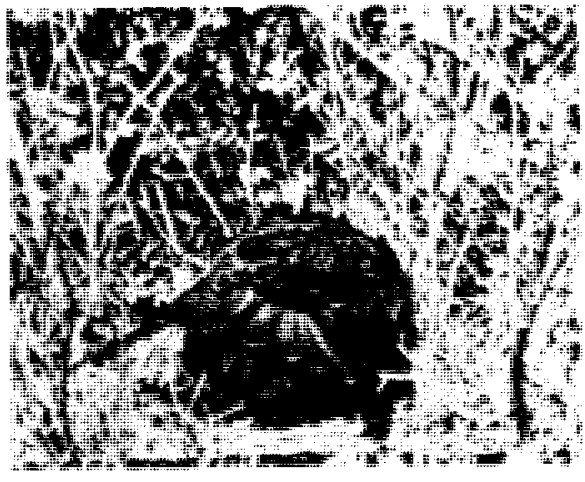

FIGURE 29. Typical shading position of female Swainson's Hawks.

\section{Feeding}

The adults picked apart the delivered prey and presented it piece by piece to the young. Such feedings usually required about 10 minutes, seldom exceeding 15 minutes. Figure 30 reveals the number of feedings

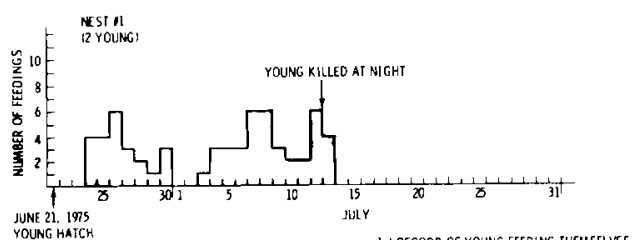
JUNE 21.1975
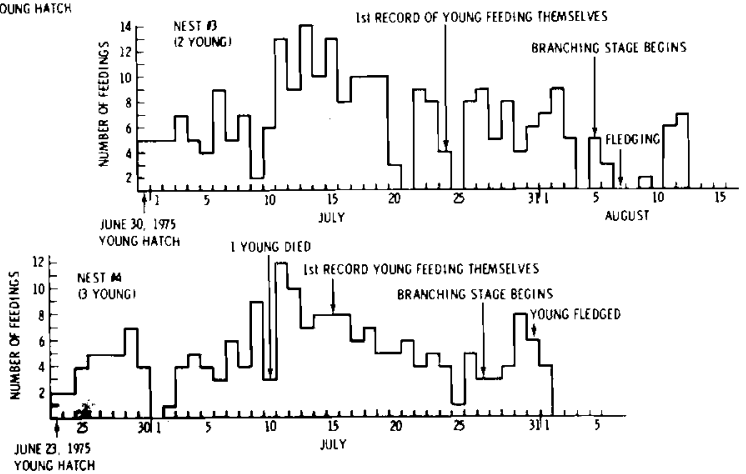

FIGURE 30. Feeding record of nestling Swainson's Hawks. recorded each day at nests 1,3 and 4 . Of interest is the apparent increase in feeding frequency when young were 10-15 days old and the gradual decrease prior to fledging.

Young were mature enough to tear the prey apart when 23-26 days old. Females periodically fed the young until they were 27-32 days old. Zarn (1975) reports that American Rough-legged Hawks begin to tear prey apart at about the 25 th day, and Matray (1974) indicates that Broad-winged Hawk young are capable of feeding themselves at 24 to 28 days of age.

The female attended the young by standing on or next to the nest when she was not feeding, brooding or shading them. During this time, the female of ten preened herse if or stood sentry over her young.

\section{NESTLING DEVELOPMENT AND BEHAVIOR}

\section{Duration of Nestling Period}

The length of time between hatching and fledging is reported in Table 9. The nestling periods reported for congeneric species are:

1. Red-tailed Hawks, 41 days (Wiley, 1975), 44 days (Luttich et al., 1971), and 45-46 days (Fitch et a 1., 1946).

2. Red-shouldered Hawks (Buteo lineatus), 45 days (Wiley, 1975).

3. American Rough-leqged Hawk (Buteo lagopus sanctijohann is), $36-\overline{40 \text { days }}$ (Zarn, 1975).

4. Ferruginous Hawks, 38-50 days (0lendorff, 1973b; Eyre and Paul, 1973; Smith and Murphy, 1978).

Development

At nest sites 1,3 , and 4 , time-lapse photography made a daily record of young development. For the first 8 to 10 days, the young were quite inactive and rested most of the time. Activity during this period was associated primarily with feeding. Young were unable to stand on their feet until 13 to 17 days of age. Until that time, all moving about was done by crawling about on the tarsi.

The first signs of sibling aggression over food were noted at 27 to 30 days of age when the young began tearing apart prey themse lves.

Young were first noted exercising their wings when 29 to 33 days old. Exercising 
TABLE 9. Nestling Period of Swainson's Hawk Young

in Southeastern Washington - 1976

\begin{tabular}{|c|c|c|c|c|c|c|c|c|c|c|}
\hline \multirow[t]{2}{*}{ Nest No. } & \multirow[t]{2}{*}{$\begin{array}{c}\text { No. } \\
\text { Young }\end{array}$} & \multicolumn{3}{|c|}{ Dated Hatched } & \multicolumn{3}{|c|}{ Date F ledged } & \multicolumn{3}{|c|}{$\begin{array}{l}\text { Number of days from } \\
\text { hatching to fledging }\end{array}$} \\
\hline & & 1st & 2nd & 3rd & $\underline{1 s t}$ & 2nd & 3rd & $\underline{\text { lst }}$ & 2nd & $3 r d$ \\
\hline 9 & 3 & June 18 & June 18 & June 19 & Aug 2 & Aug 3 & Aug 3 & 46 & 47 & 46 \\
\hline 2 & 2 & June 17 & June 18 & & Aug 1 & Aug 1 & & & 45 & 44 \\
\hline 1 & 2 & June 10 & June 11 & & July 24 & July 25 & & 45 & 45 & \\
\hline 6 & 2 & June 9 & June 10 & & July 20 & July 21 & & 42 & 42 & \\
\hline 4 & 3 & June 21 & June 22 & June 23 & July 29 & July 31 & Aug 2 & 39 & 40 & 41 \\
\hline 3 & 2 & June 28 & June 29 & & Aug 4 & Aug 7 & & 38 & 40 & \\
\hline
\end{tabular}

involved a flapping of the wings as though trying to lift off. Most wing exercising occurred in early morning and late evening, when temperature and incoming solar radiation were at their daytime minimums.

Nestlings ventured onto limbs supporting the nests when 33 to 27 days of age. The older nestling of nest 4 was 35 days old when it first ventured on to a limb, while the oldest nestling at nest 3 was 37 days old. Young quickly adapted to the branches and spent little time on the nest. Time spent on the nest was associated with feeding and resting. Young generally used the nest while roosting at night. Fledging occurred when young were between 38 and 46 days of age.

\section{Fratricide and Cannibalism}

On two separate occasions on the Hanford Site, nestling mortality was attributed to fratricide. The first occasion involved nest 10 , which contained three young about five weeks old. On 9 July 1975, the young at this nest were observed during a routine check of nestling development. One of the young was much smaller than the other nestlings but otherwise appeared healthy. The following day, I returned to band the young, and found only the two larger young and the tarsi and attached toes and claws of the smaller young. Presumably it was killed and eaten by its nest mates. Pilz (1976) found similar evidence suggesting a case of fratricide and cannibalism by the Swainson's Hawk in southern New Mexico.

The second occasion, occurring at nest 4 on 10 July 1975, involved three young. Two were several days more advanced in growth than the third. In examining time-lapse film, I noted that the smaller nestling for several preceding days was always forced from the shaded sections of the nest. On $10 \mathrm{July}$, the film revealed one of the larger nestlings pushing at the smaller, finally forcing it over the lip of the nest. No trace of the bird could be found on 12 July during film changing. I suspect the nestling was eaten by a coyote (Canis latrans) since coyotes were abundant in the area, and often fed upon scraps discarded from the nest.

\section{POST-FLEDGLING PERIOD}

As young Swainson's Hawks develop, increasingly greater amounts of time are used in exercising, particularly their wings. Eventually young reach the stage where they spend a great deal of time on branches of the nest tree and make short attempts to fly from one branch to another. This stage usually occurs within a week of first flight and is called the "branching stage." It could also be termed the "fledging period" since the young are equipped with the feathers necessary for flight. This period was discussed in the previous section. The first flight of the young from the nest tree marks the beginning of the post-fledging period.

Post-fledging behavior was recorded for 18 young from seven nest sites in the summer of 1975 on the Hanford Site. Field observations were made for approximately 80 hours per week nearly equally divided among the nest sites. Ten of those fledged young were equipped with radiotransmitters on which daily attempts were made to determine 
their location. The nest sites and number of young observed were:

\begin{tabular}{|c|c|c|}
\hline $\begin{array}{l}\text { Nest Site } \\
\text { Number }\end{array}$ & $\frac{\text { Number of }}{\text { Observed }}$ & $\frac{\text { Fledged Young }}{\text { Radiotagged }}$ \\
\hline 1 & 2 & 1 \\
\hline 4 & 3 & 2 \\
\hline 7 & 2 & 1 \\
\hline 8 & 3 & 2 \\
\hline 10 & 2 & 2 \\
\hline 17 & 3 & 0 \\
\hline 19 & 3 & 2 \\
\hline
\end{tabular}

Table 10 shows the time interval between the date of fledging and date of migration for 15 individuals from six nests. Of 13 hawks which survived to migrate, the mean number of days between fledging and migration was 29.2 with a range from 22 to 38 days. During this interval, all observed young stayed within the adult territory. During the first two to four days after fledging, young occasionally returned to the nest to feed or rest. From day 5 onward, young generally spent most of their time perched in trees or on power poles. The distribution of poles and trees strongly influenced the daily movement patterns of young birds. When few tall perches existed as was the case at nest sites 1 and 4 , movements of young were restricted to these limited perches. At nest sites $7,8,10$, and 19, power poles and/or trees were abundant and movements of young closely tracked the availability of these objects. vered itself into the upper branches. This was true in four cases where the first flight was observed. After reaching some high point, the young generally perched briefly and then made a short flight to an adjacent tree. At nest 17, two young flew about $30 \mathrm{~m}$ to a dead tree. The third young made a very unstable, gliding-flapping flight once around the nest tree slowly descending to the ground adjacent to the nest tree. The bird observed at nest 7 flew about $20 \mathrm{~m}$ to a nearby $1 \mathrm{imb}$ of a fallen dead tree. All observed first flights occurred between 1000 and 1130 hours. After the first flight, the remainder of the first day was primarily spent perched either in the nest tree or nearby trees or structures. At nest 17 the first two birds to fledge spent the day perched in the crown of the nest tree. (A rainstorm which began around noon probably had a major influence on their behavior.) The third bird to fledge at nest 17 made five short flights of less than 15-second durations the day of fledging. Two were directed toward adults carrying in prey. In one instance, the adult female flew to a tree near the nest tree and perched with a dead Western Yellow-bellied Racer. All three young flew to her and one of the first fledged was successful in securing the prey. In the second instance, the young hawk again flew to the female who had landed in the next tree with another snake. This time neither of the other young followed and the third young to fledge received the prey. The three other flights were between the nest tree and adjacent trees.

TABLE 10. Post-Fledging Period of Swainson's Hawks

in Southeastern Washington - 1976

No.

Nest No. Young

$\begin{array}{rr}4 & 3 \\ 1 & 2 \\ 7 & 2 \\ 19 & 3 \\ 17 & 3 \\ 10 & 2\end{array}$

Date Each Young Fledged

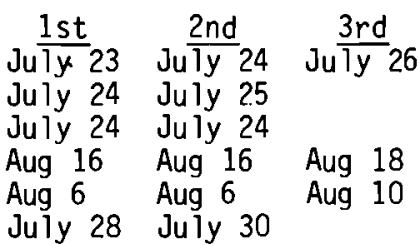

Date Each Young Migrated

\begin{tabular}{|c|c|c|c|c|}
\hline $\begin{array}{l}\text { 1st } \\
\text { Aug } 29 \\
\text { Aug } 26 \\
\text { Aug } 26 \\
\text { Sept } 8 \\
\text { Aug } 29 \\
\text { Aug } 27\end{array}$ & $\begin{array}{l}\frac{2 n d}{\text { died }} \\
\text { died } \\
\text { Aug } 26 \\
\text { Sept } 8 \\
\text { Aug } 29 \\
\text { Aug } 30\end{array}$ & $\frac{3 r d}{A u g} 29$ & $\begin{array}{l}\frac{1 s t}{38} \\
33 \\
34 \\
25 \\
24 \\
31\end{array}$ & $\begin{array}{l}\frac{2 n d}{--} \\
34 \\
25 \\
24 \\
32\end{array}$ \\
\hline
\end{tabular}

Number of Days Between Fledging and Migration
In order to thoroughly analyze the behavioral changes associated with post-fledging development, a generalized developmental sketch subdivided into four-day intervals is presented below.

\section{POST-FLEDGING BEHAVIOR}

Day 1 through 4

When preparing to make the first flight from the nest tree, the young bird maneu-
For the next three days, the young made few flights. Flying was primarily directed toward adults carrying prey. When a parent bird approached, the young began the foodbegging scream (keeee Keeeee). As the parent neared, the young generally took flight in pursuit of the parent and prey. The parent either landed with the prey and allowed the first young that approached to seize it, or dropped the prey to the ground. During the first 4 days, flight by the young were fairly short, lasting from 5 to 20 
seconds, with flights of about 10 seconds being most common. The flight of the young hawks is not graceful. It is a combination of gliding and flapping, and is generally wobbly. Most of the unsteadiness is in flapping takeoffs and landings. Apparently the newly fledged birds also have difficulty coordinating their wings and feet. On several occasions while attempting to land on limbs, young did not grasp onto the intended perch and ended up falling to the ground or to a foothold on a limb unt $i l$ they fell. Their flying was directed almost totally to securing prey brought in by adults. Few flights exceeded more than $10 \mathrm{~m}$ above ground.

Day 5 through 8

During this period the young flew whenever adults brought food into the nest vicinity. After feeding, young occasionally made short flights, but most of ten did not fly unless pursuing an adult carrying prey. The longest flight time recorded through day 7 was 40 seconds.

Young were quite social, often sitting together on the same perch. When an adult arrived with prey, they were quick to pursue. The first bird to the adult generally secured the food item. Sharing of food was seldom observed among the young. Instead, those unsuccessful in securing prey sat near the dining young and screamed incessantly. This did not cease until all young had been fed and were no longer hungry.

\section{Day 9 through 12}

The young developed expertise in flying during this time. At day 12 after fledging the young at nest site 17 were observed soaring for the first time. One young soared for over an hour. Most flights were confined to within a $100 \mathrm{~m}$ of the nest during this period. Also, at day 12, aerial transfers of prey were observed between young and adult birds. In one instance, a young hawk flew after the adult female and tried to grasp the prey by extending its legs forward under its body and under the tail of the female. The female dropped the prey and the prey transfer was unsuccessful. The adult recovered the prey in mid-air and the young again attempted the transfer. This time transfer was successful, using the same technique as before. 0ther food transfers were observed between adults and young during the later days of this time period. Several transfers occurred when a young flew directly broadside to the adult extending its feet toward the prey. Light collisions often resulted.

When not feeding, the young spent most of the ir time perched together or soaring together. While soaring, the young often flew at one another and often touched their feet together. This behavior was similar to the food transfer observed between the adult and young.

\section{Day 13 through 16}

The young flew often and were quite expert at soaring by this time. On several occasions, young were observed soaring over $250 \mathrm{~m}$ away from the nest.

Young were not observed hunting for themselves. They remained totally dependent on adults for their food. In receiving food, adults seldom made direct transfers. Most prey items were dropped while soaring. The young generally caught the prey while it fell and then took it to an elevated perch or to the ground where it was eaten. Aggression over food among the young was quite apparent. Attempts at aerial robbing were frequent and often resulted in a tugof-war until one young succeeded in making off with the prey.

\section{Day 17 through 20}

The young spent a great deal of time flying during this period. Flights lasting 1 to 2 hours were common. Most flying can be characterized as soaring but the first stooping flights were also observed. In stooping, the young would first rise to a height of 100 to $350 \mathrm{~m}$ where they would then soar above in large circles or in long straight paths. At some point in this soar, the birds would then fold their wings close to the ir bodies and dive toward the ground. Upon reaching a point within 5 to $10 \mathrm{~m}$ above ground, they would pull out of the dive in an upward arc and flap or glide back to a higher altitude. The stooping flights were often directed at one another, at a parent bird or at some flying or running animal. No incidences of prey capture by young were observed.

Adults fed the young far less often during this period. Prey was brought in only twice or three times per day. Young were observed catching and feeding on insects, primarily grasshoppers. This was accomplished by walking about and flushing their prey and then pouncing on and securing the intended victim in their talons. None of the young hawks were observed taking vertebrates.

\section{Day 21 through 25}

Five of the 15 young that survived the post-fledging period migrated on day 24 and one on day 22. Only two young were observed killing prey larger than insects during the day 21-25 period. Both kills were made 
on the ground at the terminus of a soaring flight from about 75 m elevation. Both times snakes were the prey.

The young were still quite dependent on the adults for food. Whenever an adult approached with prey, the young pursued with haste. Once a young secured the prey item, the other sibling usually tried to steal the food, often with a great deal of aggression.

\section{Day 26 through 29}

Activity in this time period closely resembled that of the preceding interval. Young soared and flew about a good deal and attempted few kills on their own. All observed kills by young were of snakes and insects. Parent birds continued to provide the majority of the young's food.

\section{Day 30 through 33}

Three other young migrated during this period. One young departed on day 31, one on day 32 and one on day 33. The ir behavior and activities prior to the migration day were similar to that of young that migrated during the 21-29 day period; however, several new hunting techniques were observed. One young employed a technique of flying close to the ground, weaving in and out of the sagebrush. The flight was accipiterine; it was a quick flapping flight which showed a tremendous control of tail and wing movements. No kills were observed being made with this technique, but prey (jackrabbits and small birds) were pursued. This type of hunting technique was often seen to be used by the adult Swainson's Hawks and proved quite efficient in capturing ground squirrels and rabbits.

\section{Day 34 through 39}

One young migrated on day 35 and the last young migrated on day 39 . Both of these birds were from nest 4 . The activities and behavior of both young were again similar to those of young from day 21-33. The adults continued to supply the young with the majority of their food, but young spent considerable time scrambling around on the ground catching large insects, primarily grasshoppers. Several snake kills were observed. The young spent a great deal of time sitting and preening and often were observed soaring over $400 \mathrm{~m}$ high and $1000 \mathrm{~m}$ from the nest site.

\section{MORTALITY}

Of the 15 young observed during the postfledging period, two died before migration. One young at nest site 1 was killed 22 days after fledging by a large mamalian carni- vore, perhaps a Coyote or a Bobcat (Lynx rufus). (Coyotes were of ten observed near nest 1 and on several occasions were seen eating regurgitated hawk castings and bits of uneaten prey from under the nest tree.) The hawk was killed on the ground in a thick stand of Big Sagebrush. The dense vegetation undoubtedly made an undetected approach easy for the Coyote and may have hampered a quick takeoff by the young hawk. The hawk also was wearing a $25 \mathrm{~g}$ radiotransmitter back package which may have hindered the bird's flight. Tooth marks in the dental acrylic covering of the transmitter and sheared feathers provided evidence that a mammalian carnivore probably was responsible for the kill.

Young at nest 4 was apparently killed by electrocution. Power poles near the nest tree were used extensively for perching by the young hawks. On several occasions, young flew to the poles to consume prey. If the young had landed on the wooden power pole or a wire and had been carrying a snake, it is possible that a dangling snake could have made contact with a power line, resulting in a short circuit and hence the electrocution of the hawk.

During 1975 two other incidents of postfledging mortality were also observed. At nest 8 on the Hanford Site two young were killed by predators. A band from one young was found $500 \mathrm{~m}$ from its nest under a Great Horned OWl roost while the second bird was found $300 \mathrm{~m}$ from its nest under a Chinese Elm tree. Great Horned OWl feathers and a casting containing Swainson's Hawk feathers were also found under the tree. Of 50 young fledged during 1975 and 1976, there were only four records of post-fledging mortality.

DAILY MOVEMENTS OF FLEDGLINGS AND SIZE OF POST-FLEDGING AREA

Figure 31 shows the areas used by young during the post-fledging period. The mean size of use areas was $1.85+\mathrm{S} . \mathrm{E}_{2} 0.509 \mathrm{~km}^{2}$ ranging from $0.76 \mathrm{~km}^{2}$ to $3 . \overline{50} \mathrm{~km}^{2}$. In examining the size of the post-fledging areas for six nest sites, it became apparent that the size of the areas varied directly with the availability and homogeneity of perching structures (power poles, fence posts and trees) within the parent territory. Nest sites 1 and 4 (Fig. 31) consisted of small groves of Black Locust trees (five trees were present at nest 1 and four at nest 4) with a single row of power poles coming within $100 \mathrm{~m}$ of the nest at each location. The movements of young at these nest sites were strongly affected by the arrangement of perching structures. At nest sites 7,8 , 10 , and 19, trees and power poles were somewhat homogeneously situated around the 

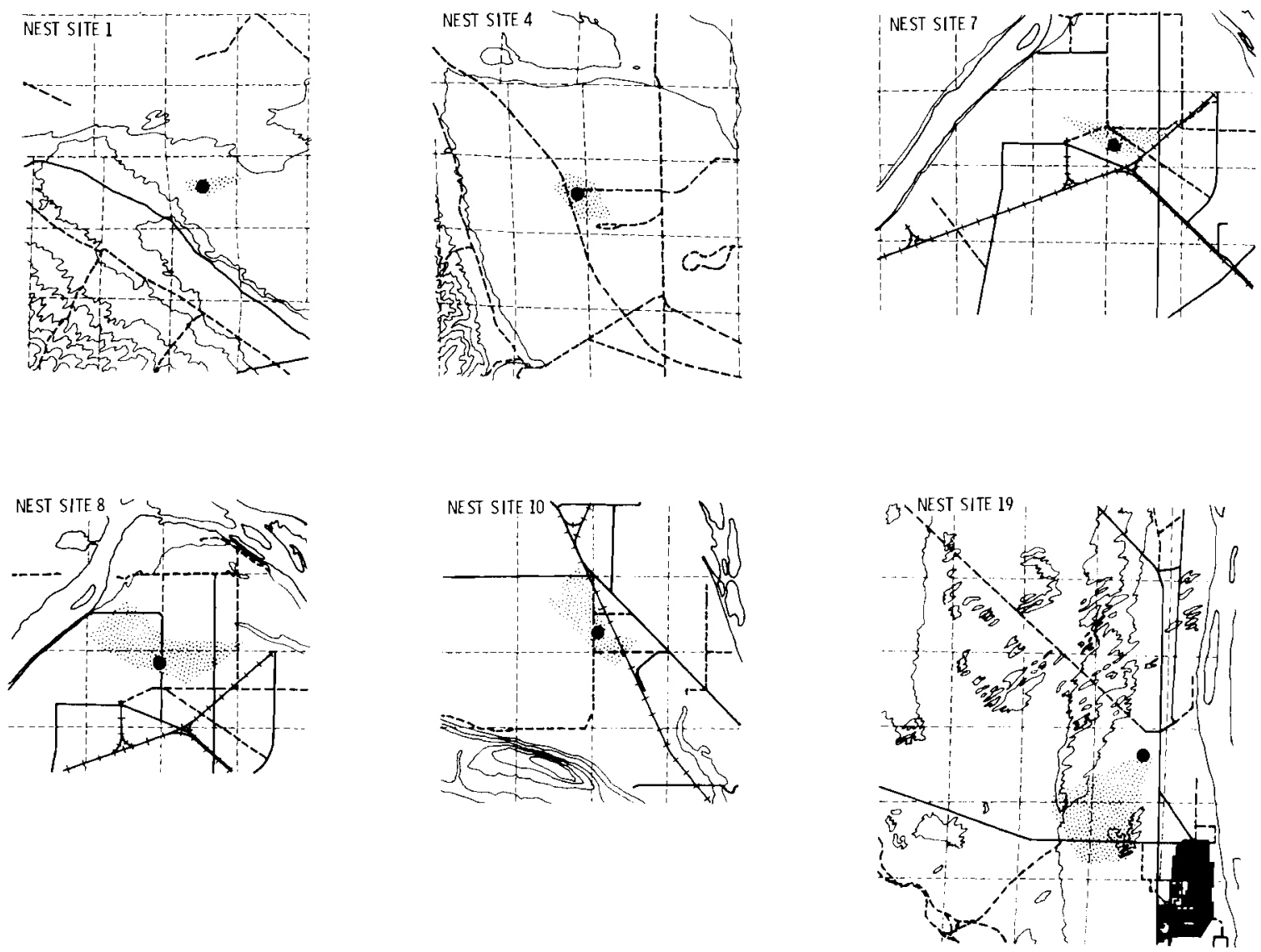

FIGURE 31. Home ranges of fledgling Swainson's Hawks represented by dotted area. Dashed lines are land sections and represent distances in square miles.

nest tree. Movements of young were less grouped in these areas and young hawks ranged over larger areas. The young apparently used the perches available within the adult territory and freely moved about if perches were available. If perches were scarce, the young simply used those perches that were present and did not move much elsewhere.

For the first 7 to 10 days, young stayed near the nest tree and few flights were made. Much time was spent perched on or near the nest. When they did fly, they chased adults carrying prey. The longest flight observed to day 7 lasted only 40 seconds and the young did not fly over $250 \mathrm{~m}$ from the nest tree. At nest site 10 , one young flew about $325 \mathrm{~m}$ away from the nest on the eighth day and on the tenth day was observed at three different times at 300,550 , and $1000 \mathrm{~m}$ away from the nest. Few of the other young ventured to the 1000 mark, generally staying within the $500 \mathrm{~m}$ range.
During the 11th through the 20th day, young at nest 10 were often recorded over $1000 \mathrm{~m}$ from the nest tree. Young at nest site 19 also ventured over $1000 \mathrm{~m}$ from their nest and averaged about $1600 \mathrm{~m}$ away, never exceeding $2300 \mathrm{~m}$. A 11 three young at nest 19 seldom returned to the nest tree during this period. This was probably due to the presence of earth-moving equipment and workmen stationed within $200 \mathrm{~m}$ of the nest tree. Young at the other nest sites did not venture as far from the nest tree as the young from nest 10 or 19 . They usually stayed within $500 \mathrm{~m}$ of the nest tree, seldom exceeding $700 \mathrm{~m}$ and rarely $1000 \mathrm{~m}$.

Young at nest sites 1 and 4 had the most restricted movement patterns and were usual$1 y$ with $500 \mathrm{~m}$ of the nest during the entire post-fledging period.

From day 20 until migratory departure, the movement of young was similar to the 11-20 day period. Until the day of departure, the 
young remained within the adult territory and were associated with the parent birds. On departure, the adults and young separated. There seemed to be no family ties and young generally departed alone. Flocks may form, however, during the migratory period.

The average length of time young associated with the parent birds was 29 days. This corresponds with the post-fledging period. The average length of time young Red-tailed Hawks associate with the parent birds has been reported as 46 days after fledging (Johnson, 1973). This extended association with the adults helps the young to survive, since they receive supplemental food from adults while learning to hunt. Johnson (1973) observed adults bringing food to young up to 34 days after fledging and found that young also had little observed hunting success during this same period. The earliest date she saw a young Red-tail killing a small mammal was 39 days after fledging.

Considering the short span of time Swainson's Hawks associate with the adults during the post-fledging period and the few observed kills they made, it is difficult to imagine how young Swainson's hawks live to adulthood. The reliance of young on insects as prey has some survival value. Little hunting expertise is needed to catch grasshoppers and other insects and until vertebrate prey hunting techniques are learned, insects may play an important role in the diet of the young.

\section{VOCALIZATIONS}

Four different calls were heard during this study. I have labeled them as 1) solicitation call, 2) agonistic pursuit cal1, 3) hunger screams by young and 4) adult scream. Each of these calls seemed to serve a specific function because each was emitted either before or during a particular activity.

\section{SOLICITATION CALL}

This particular call is voiced probably by the female during copulation. It is described and its significance discussed under the copulation section of this report.

\section{AGONISTIC PURSUIT CALL}

During an agonistic boundary dispute between raptor species, Swainson's Hawks may give this call. The call seems to be a nonviolent signal to an intruder to leave the area.

\section{HUNGER SCREAM OF YOUNG}

This was the most frequently heard call given by nestling and post-fledging hawks. Hungry young emitted the cry whenever they observed adults carrying prey. Young also directed this cry toward adult hawks of other species and at siblings.

\section{ADULT SCREAM}

When an intruder steps or flies into their home range, this call is given by the adults. Human intruders most often provoked hawks to emit this call. Figure 32 provides a sonogram of adult screams from two nest sites on the Hanford Site. The sound of this call is keee00000ee or keee0000. It generally starts out a high pitch, fading off toward the end.
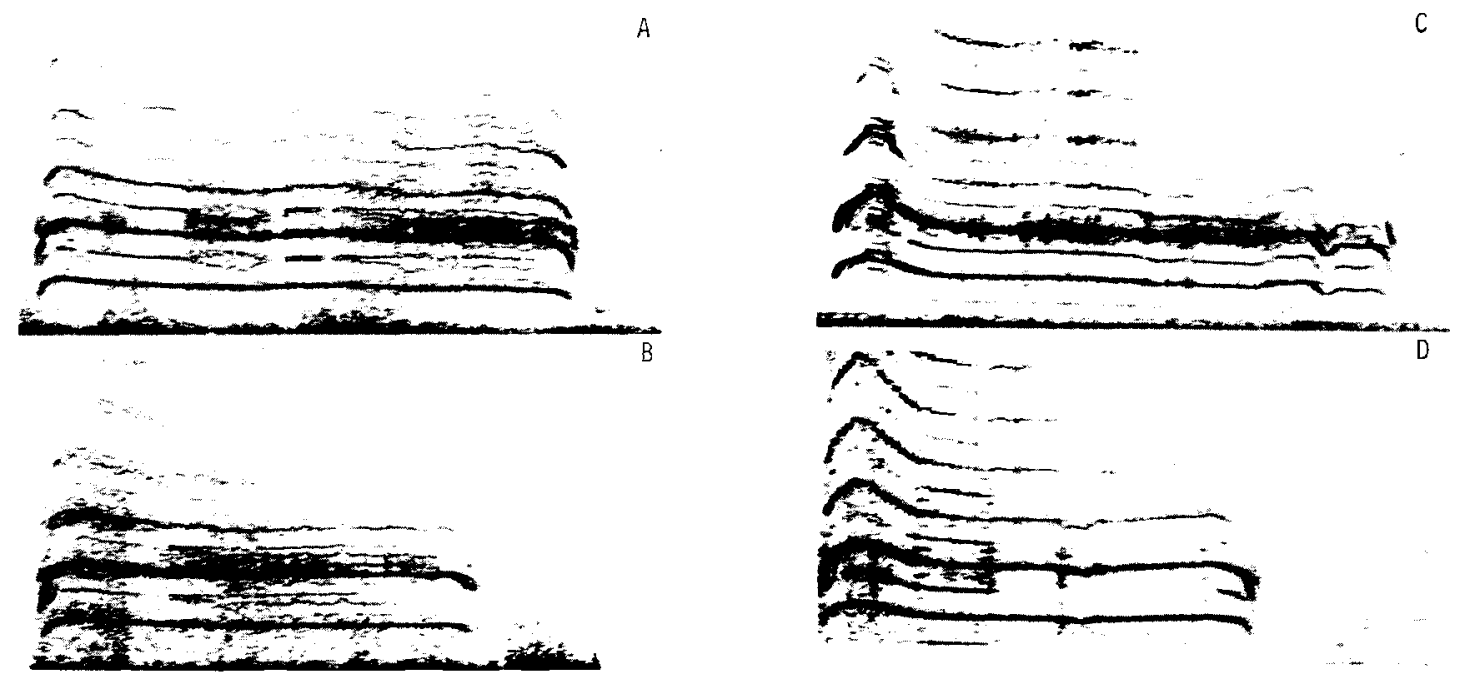

FIGURE 32. Sonograms of adult distress calls. (A) Male from nest site 19, Hanford Site. (B) Female from nest site 19, Hanford Site. (C) Female from nest site 3 , Hanford Site, (D) Male from nest site 3, Hanford Site. 


\section{TERR I TORIAL I TY}

Nice (1941) provided a comprehensive review of the concept of territoriality and classified a number of different kinds of territories based on the means of the ir establishment and defense. Noble (1939), Odum and Kuenzler (1955), Burt (1940), and Pitelka (1959) also provide definitions of territoriality.

In this study, Odum and Kuenzler's (1955) "Maximum Home Range" concept seemed to be most appropriate to apply since very few instances of territorial defense or intraspecific home range over lap were noted in the Swainson's Hawks. In using this method, the positions and movement of raptors are plotted directly onto scale maps carried into the field. The extreme outermost points on the map are then connected with straight lines to form a polygon, the area of which may be determined.

The area contained with in the polygon represents the maximum home range of the bird. This area is not to be confused with the "utilized territory or home range," which is influenced by the distribution of habitat features within the maximum home range area, and the location of perches, and feeding and nesting sites. The home ranges plotted in 1976 were derived from no less than 30 observation points for each eight pair of hawks. One adult bird, either male or female, from each of seven pairs was radiotagged and its movement recorded at least twice daily over a 15-day period. Observations on one untagged adult also provided data on home range size.

The tagging of single birds in each area biased the home range area determination in favor of the radiotagged bird, since it was most easily found. This bias, however, provided for a comparison of home range sizes based on sex differences. Observations on tagged and untagged birds were made throughout the nesting season, but over $90 \%$ of the observations were made prior to the fledging of young.

\section{HOME RANGE AREA}

The home range areas determined in 1976 for Swainson's Hawks are presented in Fig. 33 and 34 and in Table 11 gives the home range sizes. The size and shape of these areas appeared to be a function of topography of the surrounding area, breeding population densities of congeneric species, and six of the most frequently observed individuals of the Swainson's Hawk pair.

The home ranges of the eight pairs of Swainson's Hawks on the Hanford study area
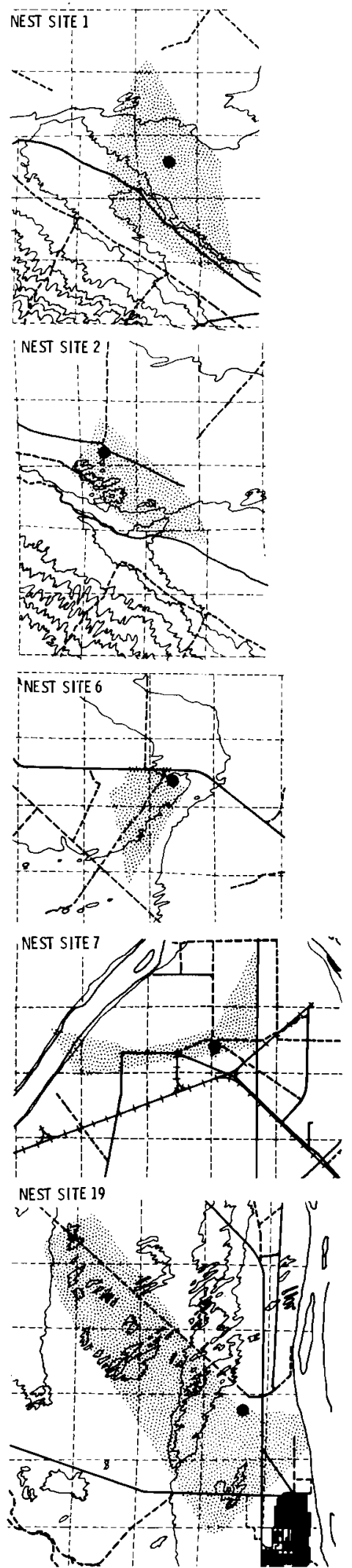

FIGURE 33. Home range size of adult male Swainson's Hawks represented by dotted areas. Dashed lines are land sections and represent distance in square miles. 


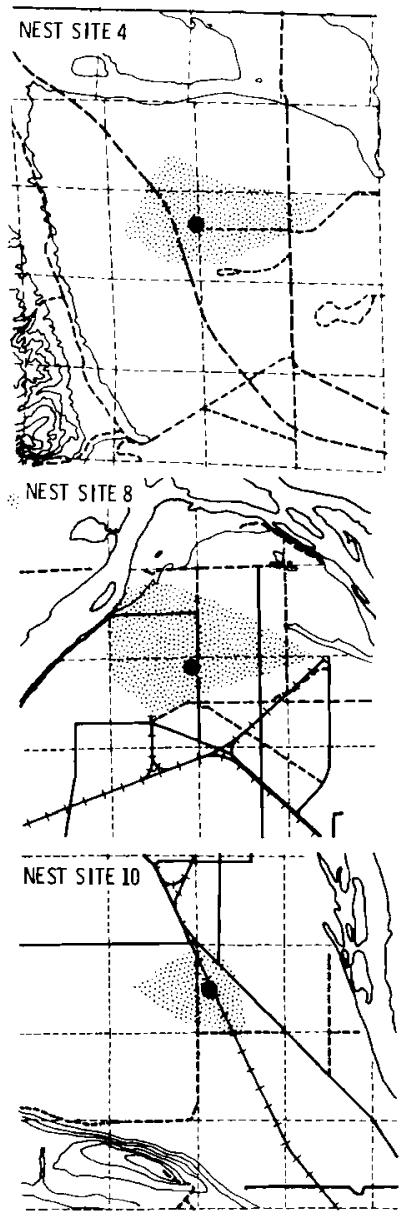

FIGURE 34. Home range size of adult female Swainson's Hawks represented by dotted area. Dashed lines are land sections and represent distance in square miles.

TABLE 11. Home Range Sizes of Adult Swainson's Hawks on the Hanford Site - 1976

\begin{tabular}{ccc} 
Sex & $\begin{array}{c}\text { Home Range } \\
\text { Area }\left(\mathrm{km}^{2}\right)\end{array}$ & $\begin{array}{c}\text { Location } \\
\text { (Nest Site No.) }\end{array}$ \\
\cline { 2 - 3 } M & 9.24 & 1 \\
$F$ & 3.08 & 6 \\
$F$ & 3.27 & 4 \\
$M$ & 20.32 & 19 \\
$F$ & 2.63 & 10 \\
$M$ & 3.10 & 2 \\
$M$ & 3.67 & 7 \\
$F$ & 4.78 & 8
\end{tabular}

Home Ranges

Adu $7 \mathrm{t} \mathrm{Males}$

Adu $7 t$ Females

$2.51 \pm$ S.E. $1.540=9.08 \pm 3.990 \mathrm{~km}^{2}$

A11 Adu 1 ts

$$
1.33 \pm \text { S.E. } 0.180=3.44 \pm 0.470 \mathrm{~km} 2
$$

$$
2.42 \pm \text { S.E. } 0.828=6.21 \pm 2.144 \mathrm{~km}^{2}
$$

averaged $6.27+$ S.E. $2.144 \mathrm{~km}^{2}$. In home ranges where māles were observed most often, the area averaged $9.08+$ S.E. $3.990 \mathrm{~km}^{2}$ $(N=4)$ while in areas where females were most often observed the area averaged $3.44 \pm$ S.E. $0.470 \mathrm{~km}^{2}(\mathrm{~N}=4)$. When trying to determine home ranges of Swainson's Hawks, it is rather apparent that differences do exist among sexes. Males tend to range farther and do not associate with the nest to the extent that the female does. When a human approaches a nest site, the female hawk is most visible since she usually stays close to the nest. An observer positioned in a blind near a nest would therefore most frequently record positions of the female and would over look extended flights of the male. This bias can be overcome by radiotagging a sample of males and females. Since the males tend to range farther, the ir movements probably more closely represent the maximum home range while females may represent a minimum.

\section{NEST FAITHFULNESS}

Craighead and Craighead (1956) indicated that a pair of raptors often return year after year to the same nest site. However, little data exist to substantiate this claim.

In 1976, seven adult Swainson's Hawks were fitted with blue patagial wing markers to study their movements and to determine whether these birds returned the following year to the nest sites used in 1976. One of the birds at nest site 6 tore the wing marker off within one week of marking, but the others retained theirs up to migration. Five adults at nest sites $1,4,8,10$, and 19 returned in the spring of 1977 to the same nest sites used in 1976. The wing markers were intact and easily identified. The return of the five marked adults ind icates that at least some Swainson's Hawks use the same nest sites from year to year. Research planned for 1978 and beyond should provide additional data on the reuse of nest sites by Swainson's Hawks.

\section{USE OF HOME RANGES BY THREE ADULTS}

During the course of this study, I found two territories containing three adults each. The third bird in each territory (sexes unknown) was not observed laying eggs or participating in nest building or care of young. The third hawk was heard screaming at human intruders but the defense of the nest was not as aggressive as that of the nesting pair of birds. The third bird seemed to be tolerated by the nesting pair and was often seen soaring with them over the nest. The third bird sometimes disappeared for three or four days at a time, eventually returning to soar about with the others. These third 
birds probably represent adult birds unsuccessful in finding mates or perhaps birds not yet sexually mature. In either case, there appeared to be no strong bond with the pair of nesting adults.

\section{PRODUCTIVITY AND POPULATION LEVELS}

\section{NESTING PARAMETERS}

0lendorff (1973a) defined nine major parameters used in his study of productivity and population levels of birds of prey in Colorado. In his report he stressed a need for consistency in the reporting of nesting population information. His suggestions have been adopted by most researchers studying population dynamics of raptors and were used in this study. The parameters and definitions used in this study were adopted from 0 lendorff (1973a) and area as follows:

1. Breeding density--the number of potential breeding pairs per unit area. Paired, non-nesting adults showing territorial affinities and non-nesting single adult birds observed repeatedly in a known, but otherwise unoccupied territory, are included.

2. Clutch size--the number of eggs laid by pairs which lay at least one egg, usually given as an average of a number of clutches.

3. Maximum brood size--the compilation of maximum brood sizes in individual nests. Non-nesting pairs are not included in the calculations. Instances where eggs were laid but not hatched were included as zeros. Maximum brood size divided by clutch size represents the probability of fledging at the time of egg laying.

4. Fledging success--the number of young fledged from a nest in which eggs were laid, usually presented as an average. Fledging success divided by maximum brood size represents the probability of fledging at the time of egg laying.

5. Nest success--the percentage of the total number of nests under study from which young actually fledged.

6. Productivity of young in successful nests--the number of young (usually an average) fledged per nest, including only those nests from which at least one young fledged.

7. Productivity of young per known pairs-the average number of young fledged per potential adult pair. All pairs and single birds are included as potential adult pairs.
8. Productivity of younq per unit area--the average number of young fledged per unit area.

9. Biomass of young and adults--the weight of adults and the young they produced per unit area.

PRODUCTIVITY OF THE SWAINSON'S HAWK IN SOUTHEASTERN WASHINGTON

\section{Productivity}

During the course of this study ( 1973 through 1977), 92 nests known to have been used by Swainson's Hawks were studied. The studies conducted on the Hanford Site reflect the reproductive performances of adult pairs which occupied a total of twenty territories over a five-year period. No more than 17 pairs of adult birds were present during any one year. These 17 pairs probably represent the same birds returning year after year. The nests on the Hanford Site were studied intensively to obtain accurate information on clutch sizes, brood sizes, and fledging success. The first two parameters were not always determined for the nests studied throughout southeastern Washington in 1975, but fledging success was.

Table 12 provides nesting histories for all nests studied on the Hanford Site from 1973-1977 and Table 13 summarizes the reproductive performance at these nests over the five-year period. During the years 1973 and 1974, field efforts in finding nests were not intensive enough to locate every pair of Swainson's Hawks present on the 112,911 ha study area. Surveys conducted from 1975 through 1977 systematically searched all available nesting areas and these provide a complete picture of the nesting density and productivity of the species. Since the Hanford Site has been relatively undisturbed by man for over 20 years, the productivity data gathered there would most closely correspond to the reproductive potential of Swainson's Hawks under natural conditions. Data gathered on this study site may represent the productivity one would expect under near optimum conditions and serves as a control to rate the reproductive performance of other sub-populations of Swainson's Hawks nesting in southeastern Washington.

\section{CLUTCH SIZE}

Disturbance of hawks during incubation can be a significant cause of nest desertion (0lendorff, 1973a; Fyfe and 0lendorff, 1976). For this reason, few nests were visited during incubation in 1973 or 1974. Field experience gathered during these years, however, provided strong indications that nest visitations made a few days prior to hatching would not result in desertions. Field 
TABLE 12. Nesting History of the Swainson's Hawk on the Hanford Site

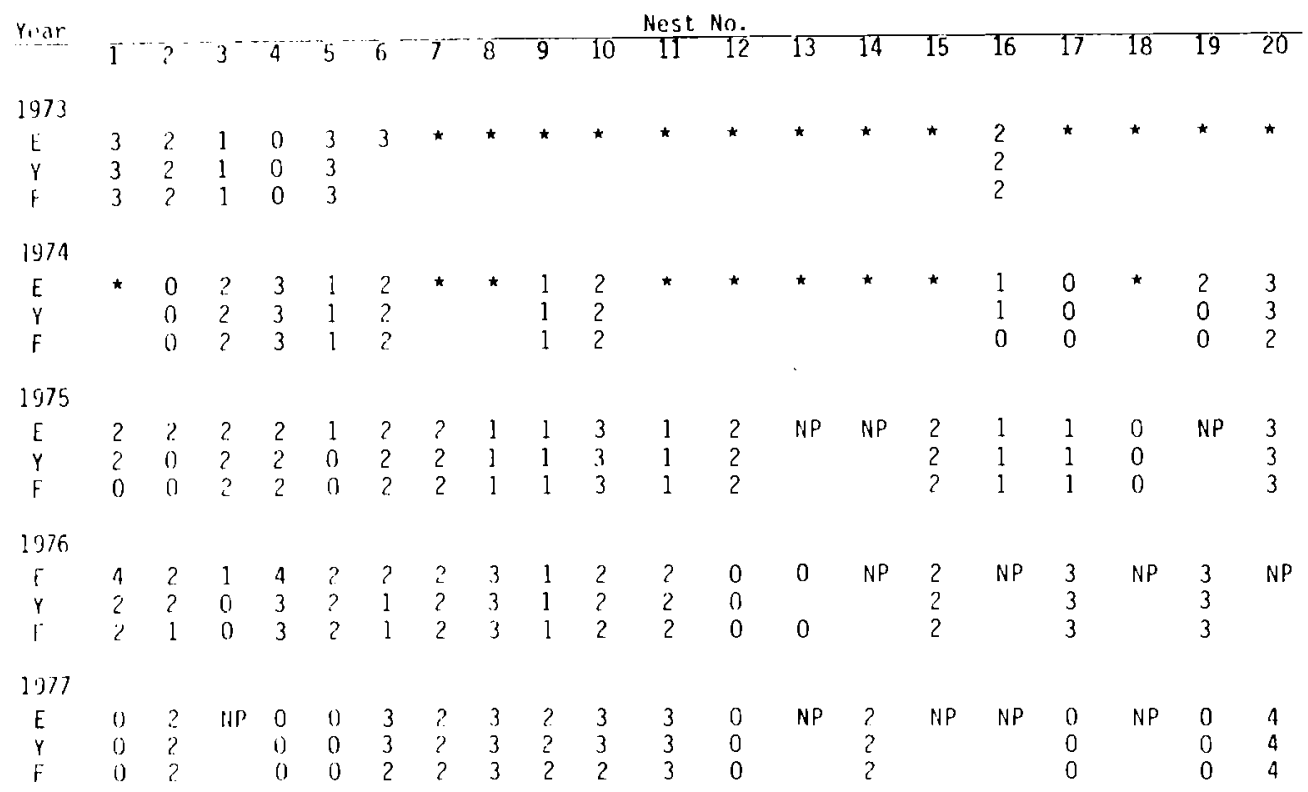

\footnotetext{
Legenul: $E=$ Mumber of equs (Inax. clutch size) $\quad *=$ Indiscovered

$Y=N a m b e r$ of young hatrhed $\quad N P=$ Adults not present, territory not occupied

$F=$ Humber of young tledged
}

TABLE 13. Productivity of Swainson's Hawk on the Hanford Site

\begin{tabular}{|c|c|c|c|c|c|c|c|c|c|c|c|}
\hline Year & Pairs & $\begin{array}{l}\text { No. Adu } 1 t \\
\text { Pairs Lay- } \\
\text { ing Eggs }\end{array}$ & $\begin{array}{l}\text { No. } \\
\text { Eggs }\end{array}$ & $\begin{array}{l}\text { No. } \\
\text { per } \\
\text { Adu } 1\end{array}$ & $\begin{array}{l}\text { Eggs } \\
\text { Known } \\
\text { It Pair }\end{array}$ & $\begin{array}{l}\text { No. } \\
\text { Young }\end{array}$ & $\begin{array}{l}\text { No. } \\
\text { per } \\
\text { Adu }\end{array}$ & $\begin{array}{l}\text { Young } \\
\text { Known } \\
\text { 1t Pair }\end{array}$ & $\begin{array}{l}\text { No. } \\
\text { Fledged }\end{array}$ & $\begin{array}{l}\text { Productivity } \\
\text { of Young per } \\
\text { Known Pair } \\
\end{array}$ & $\begin{array}{l}\text { Total } \\
\text { Young }\end{array}$ \\
\hline $\begin{array}{l}1973 \\
1974 \\
1975 \\
1976 \\
1977\end{array}$ & $\begin{array}{l}7 \\
11 \\
17 \\
16 \\
15\end{array}$ & $\begin{array}{r}6 \\
9 \\
16 \\
14 \\
9\end{array}$ & $\begin{array}{l}14 \\
17 \\
28 \\
33 \\
24\end{array}$ & $\begin{array}{l}x \\
2.0 \\
1.55 \\
1.64 \\
2.06 \\
1.6\end{array}$ & $\begin{aligned} & S . E \\
\pm & 0.436 \\
\pm & 0.312 \\
\pm & 0.191 \\
\pm & 0.295 \\
\pm & 0.375\end{aligned}$ & $\begin{array}{l}13 \\
15 \\
25 \\
28 \\
24\end{array}$ & $\begin{array}{l}x \\
1.86 \\
1.36 \\
1.47 \\
1.75 \\
1.6\end{array}$ & $\begin{aligned} & \text { S.E. } \\
\pm & 0.404 \\
\pm & 0.337 \\
\mp & 0.229 \\
\pm & 0.266 \\
\pm & 0.375\end{aligned}$ & $\begin{array}{l}13 \\
14 \\
23 \\
27 \\
22\end{array}$ & $\begin{array}{c}x \quad \text { S.E. } \\
1.86 \pm 0.404 \\
1.27 \pm 0.359 \\
1.35 \pm 0.223 \\
1.68 \pm 0.269 \\
1.47 \pm 0.321\end{array}$ & $\begin{array}{l}13 \\
14 \\
23 \\
27 \\
22\end{array}$ \\
\hline
\end{tabular}

personnel must be careful, however, not to visit nests during excessive heat or cold and to make visits as short as possible, preferably less than three to five minutes. Nests requiring excessive time for climbing should not be visited until after hatching occurs. In field studies conducted during 1975-1977, clutch size was determined for most nests during the incubation period. Nests not examined during incubation were visited soon after hatching.

Table 14 summarizes the clutch sizes in all nests where complete clutch sizes were counted on the Hanford Site, and gives the mean clutch size recorded for each year from 1973 through 1977.

Clutch size varied from a high of 2.67 in 1977 to a low of 1.75 in 1975. The average clutch size for all five years was 2.15. Of interest is the increase in clutch size from 1975 to 1977, with a corresponding decrease in number of successful nests. Individual clutch sizes also varied from year to year. In 1975, clutches of one or two eggs were common while three were rare and four nonexistent. In 1976 and 1977, clutches of three and four eggs were often found.

\section{HATCHING SUCCESS}

Only nests on the Hanford Site were visited during incubation or shortly after hatching. The values used for hatching success are therefore calculated only for the Hanford Site. Hatching success for 1975, 1976, and 1977 was $89 \%, 85 \%$, and $100 \%$ respectively (Table 15). The maximum overall average 
TABLE 14. Clutch Size in all Nests Where Complete Clutches Were Counted on the Hanford Site

\begin{tabular}{|c|c|c|c|c|c|c|}
\hline & 1973 & 1974 & 1975 & 1976 & 1977 & Totals \\
\hline Number of Nests & 6 & 9 & 16 & 14 & 9 & 54 \\
\hline Nests with 1 Egg & 1 & 3 & 6 & 2 & 0 & 12 \\
\hline Nests with 2 Eggs & 2 & 4 & 8 & 7 & 4 & 25 \\
\hline Nests with 3 Egqs & 3 & 2 & 2 & 3 & 4 & 14 \\
\hline Nests with 4 Eggs & 0 & & 0 & 2 & 1 & 3 \\
\hline Mean Clutch Size & 2.33 & 1.88 & 1.75 & 2.36 & 2.67 & 2.15 \\
\hline Standard Error & 0.333 & 0.261 & 0.171 & 0.248 & 0.236 & 0.113 \\
\hline
\end{tabular}

TABLE 15. Data from Nest Sites in which Young Fledged, Where Prior Details Were known on the Hanford Site

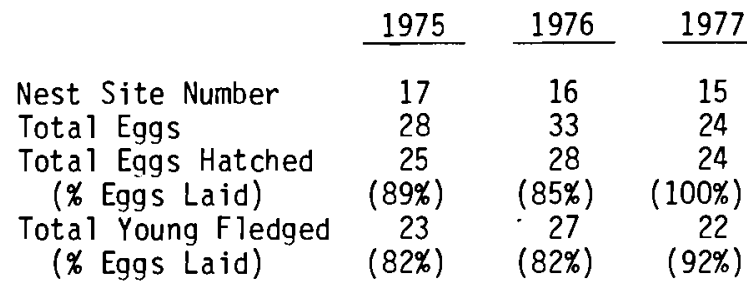

brood size for these three years was 1.97 young hatched per nests in which eggs were laid (Table 16).

\section{FLEDGING SUCCESS}

Fledging success refers to the number of young which fledge from nests in which eggs were laid. This parameter could not be determined for pairs where prior history was unknown. Data gathered at the Hanford Site intensive study area are, therefore, used in computing fledging success. Table $17 \mathrm{re-}$ veals that the number of occupied territories in which eggs were laid on the Hanford Site decreased from 16 to 9 from 1975 to 1977. With this decrease, however, came an increase in fledging success. This phenomenon apparently resulted in a relatively constant recruitment rate of young into the adult cohort from year to year. Table 15 provides additional data that indicate that the number of fledged expressed as a percentage

TABLE 16. Clutch Size, Maximum Brood Size and Fledging Success of the Swainson's Hawk in North America

\begin{tabular}{|c|c|c|c|}
\hline Area and Year & Clutch Size & Maximum Brood Size & Fledging Succes \\
\hline $\begin{array}{l}\text { Colorado (Olendorff, 1973a) } \\
1970 \\
1971 \\
1972 \\
\text { Overal1 }\end{array}$ & $\begin{array}{ll}2.41 & (22)^{\mathrm{a}} \\
2.32 & (28) \\
2.31 & (45) \\
2.34 & (95)\end{array}$ & $\begin{array}{l}1.72(18) \\
1.50(26) \\
1.86(51) \\
1.74(95)\end{array}$ & $\begin{array}{ll}1.11 & (19) \\
1.13 & (30) \\
1.24 & (70) \\
1.19 & (119)\end{array}$ \\
\hline $\begin{array}{l}\text { Utah (Smith and Murphy, 1973) } \\
\text { 1967-1970 Overall. }\end{array}$ & $2.22(5)$ & $2.0 \quad(5)$ & $1.60(4)$ \\
\hline Illino is (Keir, 1976) & - & $2.0 \quad(3)$ & $1.67(3)$ \\
\hline Wyoming (Dunk le, 1977) & $2.55(31)$ & $2.06(33)$ & $2.06(33)$ \\
\hline $\begin{array}{l}\text { Washington (this study) } \\
\text { Hanford Site } \\
1975 \\
1976 \\
1977 \\
\text { Overal1 }\end{array}$ & $\begin{array}{ll}1.75 & (16) \\
2.36 & (14) \\
2.67 & (9) \\
2.18 & (39)\end{array}$ & $\begin{array}{ll}1.56 & (16) \\
2.00 & (14) \\
2.67 & (9) \\
1.97 & (39)\end{array}$ & $\begin{array}{ll}1.44 & (16) \\
1.93 & (14) \\
2.44 & (9) \\
1.85 & (39)\end{array}$ \\
\hline
\end{tabular}

aNumbers in parentheses are the number of nests observed. 
TABLE 17. Breeding Data Summary for Swainson's Hawks

on the Hanford Site - 1975 through 1977

\begin{tabular}{|c|c|c|c|}
\hline \multirow[b]{2}{*}{ Total Occupied Territorie } & 1975 & 1976 & \multirow{2}{*}{$\begin{array}{c}1977 \\
15\end{array}$} \\
\hline & 17 & 16 & \\
\hline $\begin{array}{l}\text { Territories in which no } \\
\text { Breeding, or Breeding } \\
\text { Failed }\end{array}$ & 1 & 2 & 6 \\
\hline $\begin{array}{l}\text { Repeat Nests } \\
\text { Successful } \\
\text { Unsuccessfur }\end{array}$ & $\begin{array}{l}1 \\
1\end{array}$ & $\begin{array}{l}2 \\
2\end{array}$ & \\
\hline $\begin{array}{l}\text { Nests in Which Eggs } \\
\text { Were Laid }\end{array}$ & 16 & 14 & 9 \\
\hline $\begin{array}{l}\text { Nests from which } \\
\text { Young Fledged }\end{array}$ & 13 & 13 & 9 \\
\hline Total Young Fledged & 23 & 27 & 22 \\
\hline $\begin{array}{l}\text { Mean Young Fledged per } 1 . \\
\text { Successful Nest }\end{array}$ & $1.44 \pm$ S.E. 0.202 & $1.93 \pm$ S.E. 0.211 & $2.44 \pm$ S.E. 0.242 \\
\hline
\end{tabular}

of eggs laid varies little from year to year. This points out an interesting mechanism of population control. Apparently, in years of high nesting success, smaller clutches are laid by many fenlales, while in years of low nesting success, larger clutches are laid by fewer females. Since mortality is low, once an egg is laid, then the percentage of young surviving to fledging remains high from year to year. This results in the population remaining relatively stable even when large fluctuations in nesting success occur.

The only data collected on productivity of the Swainson's Hawk throughout its nesting range in southeastern Washington was gathered in 1975. From June through August, an attempt was made to locate as many nests as possible and to determine the number of young fledged per nest. Table 18 is a summary of the findings.

\begin{tabular}{|c|c|c|c|c|}
\hline \multirow[b]{2}{*}{ Area } & TABLE 18. & \multicolumn{2}{|c|}{$\begin{array}{l}\text { Productivity of Swainson's Hawks } \\
\text { in Southeastern Washington, } 1975\end{array}$} & \multirow[b]{2}{*}{$\begin{array}{l}\text { Avg. No. Young } \\
\text { Fledged per Nest }\end{array}$} \\
\hline & $\begin{array}{l}\text { No. of Adult } \\
\text { Pairs Present } \\
\text { with Nests } \\
\end{array}$ & $\begin{array}{l}\text { No. of Nests } \\
\text { from Which } \\
\text { Young Fledged } \\
\end{array}$ & $\begin{array}{c}\text { No. of Young } \\
\text { Fledged } \\
\end{array}$ & \\
\hline Whitman County & & & & \\
\hline $\begin{array}{l}\text { Pullman/Colfax } \\
\text { vicinity } \\
\text { S. Frank lin County }\end{array}$ & 9 & 5 & 6 & 0.67 \\
\hline $\begin{array}{l}\text { Jun iper Area } \\
\text { Grant County }\end{array}$ & 7 & 6 & 10 & 1.43 \\
\hline $\begin{array}{l}\text { Saddle Mountain Area } \\
\text { Benton County }\end{array}$ & 4 & 1 & 1 & 0.25 \\
\hline $\begin{array}{l}\text { Hanford Site } \\
\text { Benton County }\end{array}$ & 17 & 13 & 23 & 1.35 \\
\hline $\begin{array}{l}\text { Benton City Area } \\
\text { Yakima County }\end{array}$ & 2 & 1 & 3 & 1.50 \\
\hline $\begin{array}{l}\text { Yakima Firing Range } \\
\text { TOTAL }\end{array}$ & $\begin{array}{r}1 \\
43\end{array}$ & $\begin{array}{r}1 \\
29\end{array}$ & $\begin{array}{r}1 \\
51\end{array}$ & $\begin{array}{l}1.0 \\
1.19\end{array}$ \\
\hline
\end{tabular}


In examining the data from the seven areas which contributed to Table 18, I found large variations in the productivity of young per known pair. Since periodic detailed observations of each adult pair were not made, speculations are offered as to the causes for the observed variations. The Hanford Site and the juniper areas are removed from human disturbances and nest sites, and prey resources are abundant. All other areas are subject to human disturbances. The Saddle Mountain area contained nests that were of ten close to main highways and readily accessible to humans. On several occasions, picnicking and target practicing with guns were observed under or near hawk nests in this area. Nests found in the Pullman/ Colfax vicinity were not as accessible to human disturbances as the Saddle Mountain area and no acts of human interference were observed. Nevertheless, low productivity was recorded for which no clear answer exists. Perhaps abiotic parameters may have influenced the reproductive performance. The Pullman/Colfax area is an important agricultural area that has been subjected to pesticide and herbicide applications in recent years. Even after the ban of pernicious pesticides, DDT was still applied to pea crops in the Palouse hills. Chlorinated hydrocarbons have been found to cause infertility in birds of prey (Wiemeyer et al., 1975) and nesting failures due to egg shell thinning (Cade et a1., 1971; Johnson et a1., 1975). This could conceivably decrease the success of Swainson's Hawks nesting in the Pullman/Colfax area. Pesticide analyses of vegetation, prey, hawk tissues and eggs would help to determine whether past pesticide programs are having any effect on the Swainson's Hawk.

\section{PRODUCTIVITY OF SWAINSON'S HAWKS}

\section{IN NORTH AMERICA}

In order to more fully understand the health of the Swainson's Hawk population in Washington, comparisons with other North American studies are necessary. To date, four published accounts exist on the productivity of the species in North America. Olendorff (1973a) studied the Swainson's Hawk over a three-year period on an area covering and adjacent to the Pawnee National Grasslands of Colorado. Smith and Murphy (1973) examined nesting success of the hawk in Utah. Keir (1976) studied five pairs residing within $85 \mathrm{~km}$ of downtown Chicago, Illinois, and Dunkle (1977) reports on the reproduction of Swainson's Hawks on the Laramie Plains of Wyoming.

\section{Clutch Size}

Little variation seems to exist in the clutch sizes of the overall composite of successful nests (Table 15). A low of 2.18 eggs were laid for each successful nest in Washington while the Utah, Colorado, and Wyoming studies yielded $2.22,2.34$, and 2.55 eggs per successful nests respectively. In comparing these means with an ANOVA test, no significant difference was found at the $\alpha=0.05 \%$ level.

\section{Maximum Brood Size}

The maximum brood size of Swainson's Hawks have been reported by 0 lendorff (1973a), Smith and Murphy (1973), Keir (1976), and Dunk le (1977). Their findings and mine are summarized in Table 16. The overall maximum brood sizes reported by these researchers are not significantly different from those found in this study when comparing the means with an ANOVA test at $\alpha=0.05$. Yearly variations reported in this study do differ, however, and indicate that a mechanism for stabilizing productivity may exist within a population to compensate for fluctuations in other nesting parameters.

\section{Fledging Success}

Table 16 shows the fledging successes of Swainson's Hawk populations in North America. 0lendorff (1973a) reports the lowest fledging successes for North America in his Colorado study. His sample size is also nearly three times greater than any of the other studies. This in itself may be a major reason for the discrepancy. Fledging success alone does not provide the best indication of the productivity.

A better understanding of the actual production of the total population can be gained through examination of data in Table 19. The number of young fledged per adult pair is almost identical for southeastern Washington (1.19) and 0lendorff's $1000 \mathrm{~km}^{2}$ study area (1.18). The fledging success for the Hanford Site, 0lendorff's (1973a) $414 \mathrm{~km}^{2}$ study area, 1972, and Smith and Murphy's (1973) $80 \mathrm{~km}^{2}$ study area are also quite similar. Apparently the larger study areas incorporate habitat of high, average, and low suitability to hawk production. The smaller study areas probably introduce a bias since they may not represent all the available nesting habitats and may actually represent quality sites for nesting. This certainly was the case for the Hanford Site. Olendorff (1973a) and Smith and Murphy (1973) suggest this may be the case in the ir studies. The figure of 1.6 young fledged per adult pair present then could be construed to exemplify the near maximum productivity we could expect from a population of Swainson's Hawks while 1.18 and 1.19 may closely express the norm. Lower values would be representative of populations 


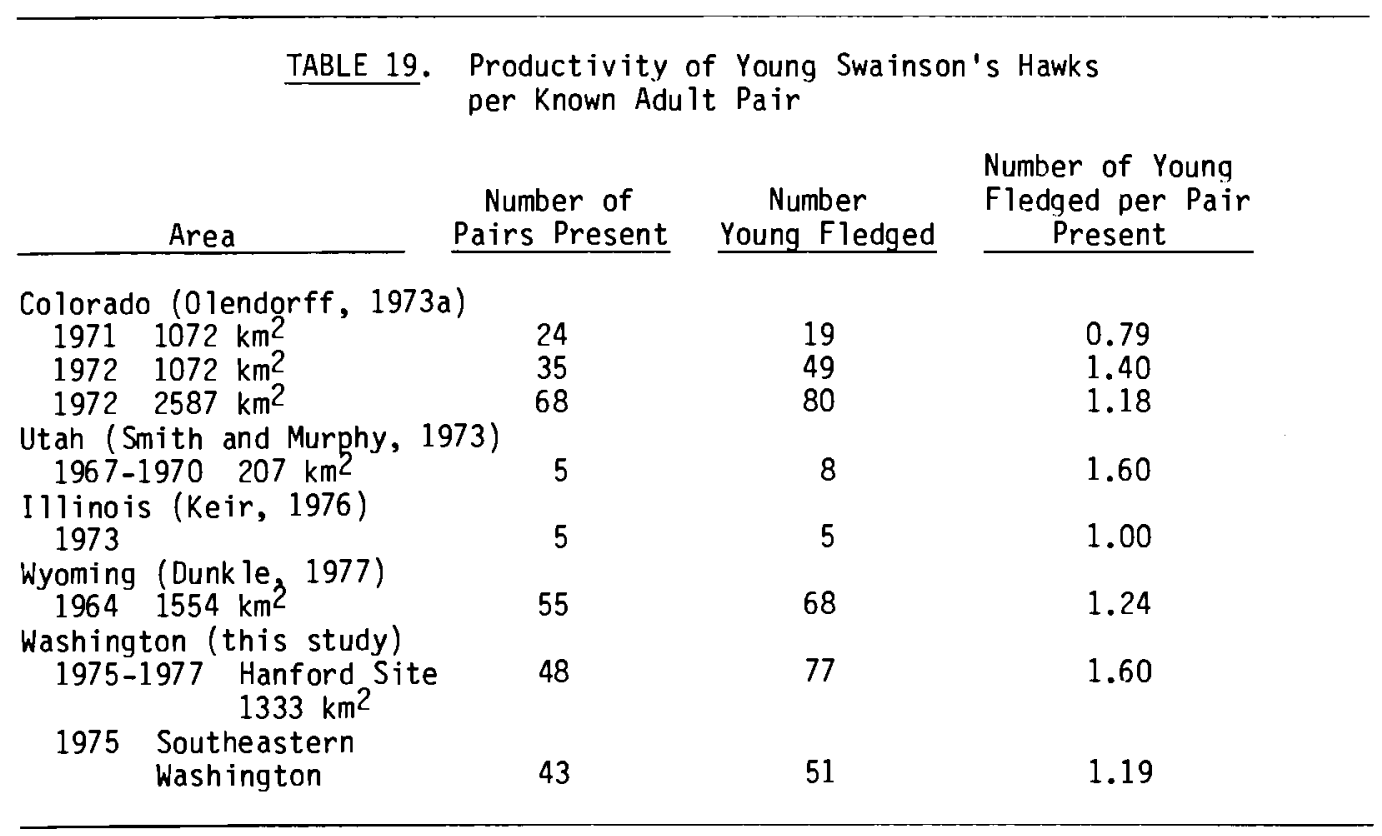

which for one reason or another are not reproducing up to norm. These populations as well as those producing at the norm would be candidates for we 11 planned management techn iques.

\section{Nesting Success}

Another parameter useful in determining the reproductive health of a hawk population is the nesting success. In this parameter, the percentage of all nests that actually fledge young is presented. This parameter combines the reproductive performance of the birds with the adequacy of the nest sites used. Table 20 presents a summary of nesting success of the Swainson's Hawk as reported in the United States. If we examine only studies with samples of 30 or more nests, a pattern in nesting success can be seen. It appears that about $50-70 \%$ of the Swainson's Hawks in North America are successful in raising young to the fledging stage. Johnson (1973) found that Red-tailed

TABLE 20. Nest Successes of Swainson's Hawks in the United States

Area and Year

Nests Successful Percentage

\begin{tabular}{|c|c|c|c|}
\hline \multicolumn{4}{|l|}{$\frac{\text { coloradeo }}{\text { (0lendorff, 1973a) }}$} \\
\hline 1971 & 24 & 8 & 33.3 \\
\hline 1972 & 35 & 24 & 70.6 \\
\hline $19722587 \mathrm{~km}^{2}$ & 68 & 38 & 56.0 \\
\hline \multicolumn{4}{|l|}{$\frac{\text { Utah }}{(\text { Smith and Murphy, 1973) }}$} \\
\hline $\begin{array}{l}\text { (Smith and Murphy, 1973) } \\
1967-1970\end{array}$ & 5 & 4 & 80.0 \\
\hline \multicolumn{4}{|l|}{ Illinois } \\
\hline (Keir, 1976) & 5 & 3 & 60.0 \\
\hline$\frac{\text { Wyoming }}{\text { (Dunkle, 1977) }}$ & 55 & 33 & 60.0 \\
\hline \multicolumn{4}{|l|}{ Washington } \\
\hline \multicolumn{4}{|l|}{$\begin{array}{l}\text { (This study) } \\
\text { Hanford Site }\end{array}$} \\
\hline 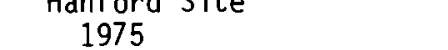 & 17 & 13 & 76.0 \\
\hline 1976 & 16 & 13 & 81.0 \\
\hline 1977 & 15 & 9 & 60.0 \\
\hline Southeastern Washington & & & \\
\hline 1975 & 43 & 31 & 72.0 \\
\hline
\end{tabular}


Hawks (Buteo jamaicensis) in Montana had a nesting success of 58.6 and $61.9 \%$ in 1971 and 1972 respectively, while Fitzner et al. (1977) indicated that several Ferruginous Hawk (Buteo regalis) populations in North Amer ica also have nesting successes that fall in the $50-70 \%$ range. This pattern seems to be common among the Buteo hawks of western North America.

\section{FOOD HABITS}

FOOD HABITS OF THE SWAINSON'S HAWK

\section{IN WASHINGTON}

Food habits data for the Swainson's Hawk in Washington were accumulated from 1973 through 1976 on the Hanford Site, and during 1975 in the Juniper study area, Pullman/ Colfax area, and at a nest site on the Yakima Firing Range, Yakima County, Washington. Three methods previously described were used to collect and analyze the prey items. Scientific names of prey species were from the following sources: mammals (Ingles, 1965), birds (A.0.U., 1957), and reptiles and amphibians (Stebbins, 1954). The resulting dietary information from these analyses provided information on the diet of hawks during the nestling and post-fledging periods. The diet of the hawks during the nestling period reflects food brought to young birds in the nest by parent birds. The diet during the post-fledging period represents a composite of foods caught by fledgings, foods brought to them by adults, and prey eaten by adults.

Time-lapse photography provided only a limited amount of data on the kinds of prey fed to nestlings by parent birds. Very small prey were not easily identifiable when viewing the Super $-8 \mathrm{~mm}$ films, so the prey composition in the diet is biased in favor of larger prey items. Also, small prey were consumed more quickly than large prey and fewer frames of $f i \mathrm{~lm}$ of these small prey items were available for analysis. Table 21 provides a breakdown of the prey that were recorded being fed to young Swainson's Hawks on the Hanford Site. Snakes comprised 77\% of the diet, lagomorphs 14\%, small mammals $4 \%$, and birds $6 \%$. Insects were not recorded. Only $38 \%$ of all prey brought to the nests were identifiable in the photographs.

Table 22 provides a comprehensive picture of individual prey items observed at Swainson's Hawk nest sites on the Hanford Site from 1973-1976. Here, snakes made up $64 \%$ of the prey, lagomorphs $11 \%$, small mammals $11 \%$ and birds $15 \%$. This percentage is close to that provided by time-lapse photography. It is clear that snakes are an important prey constituent in the diet of nestling Swainson's Hawks on the Hanford Site.
TABLE 21. Prey Fed to Nestling Swainson's Hawks as Determined from Super-8mm Time-Lapse Photography

Species

Number

\author{
Lagomorphs \\ Black-tailed Hare \\ Lepus californicus \\ Nutta11 Cottontail \\ Sylvilagus nuttallii \\ Unidentified \\ Sma 11 Mammals \\ Townsend Ground Squirrel \\ Citel lus townsendi $i$ \\ Unidentified \\ Small Birds \\ Horned Lark \\ Unidentified \\ Reptiles \\ Gopher Snake \\ Pituoph is melanoleucus \\ Western Yellow-bellied Racer \\ Coluber constrictor \\ Unidentified
}

7

Eremophila alpestris $\quad 1$

Unidentified Prey

TOTAL

Data collected at the Juniper and Pullman/ Colfax study areas and the Yakima Firing Range provide additional information on the food habits of nestling Swainson's Hawks throughout southeastern Washington. Since each of these additional locations represent different habitats and different climatic conditions of the steppe reaion, we can expect to find a somewhat different group of vertebrate and invertebrate prey species present (Stebbins, 1954; Rickard, 1960; Ingles, 1965; Robbins et al., 1966).

The diets of the Swainson's Hawks in these areas should, therefore, reflect differences in prey species present. Clearly, this is the case. The diet of the Swainson's Hawk near Pullman (Table 23) contained three mammal species (Vole, Columbian Ground Squirrel, Eastern Cottontai1), one bird species (Gray Partridge) and one snake (Garter Snake) not found in the diet of hawks on the Hanford Site. The Juniper site diet (Table 24) differed from the Hanford Site by two mammals (Washington Ground Squirrel, Kangaroo Rat) and two reptiles (Horned Lizard and Fence Lizard), while the Yakima Firing Range Site (Table 25) differed by only one mamma? species. These variations reflect the distributional differences of vertebrates in washington. The differences in diets also 
TABLE 22. Prey Fed to Young Swa inson's Hawks by Parent Birds on the Hanford Site - 1973-76

$\%$

Species

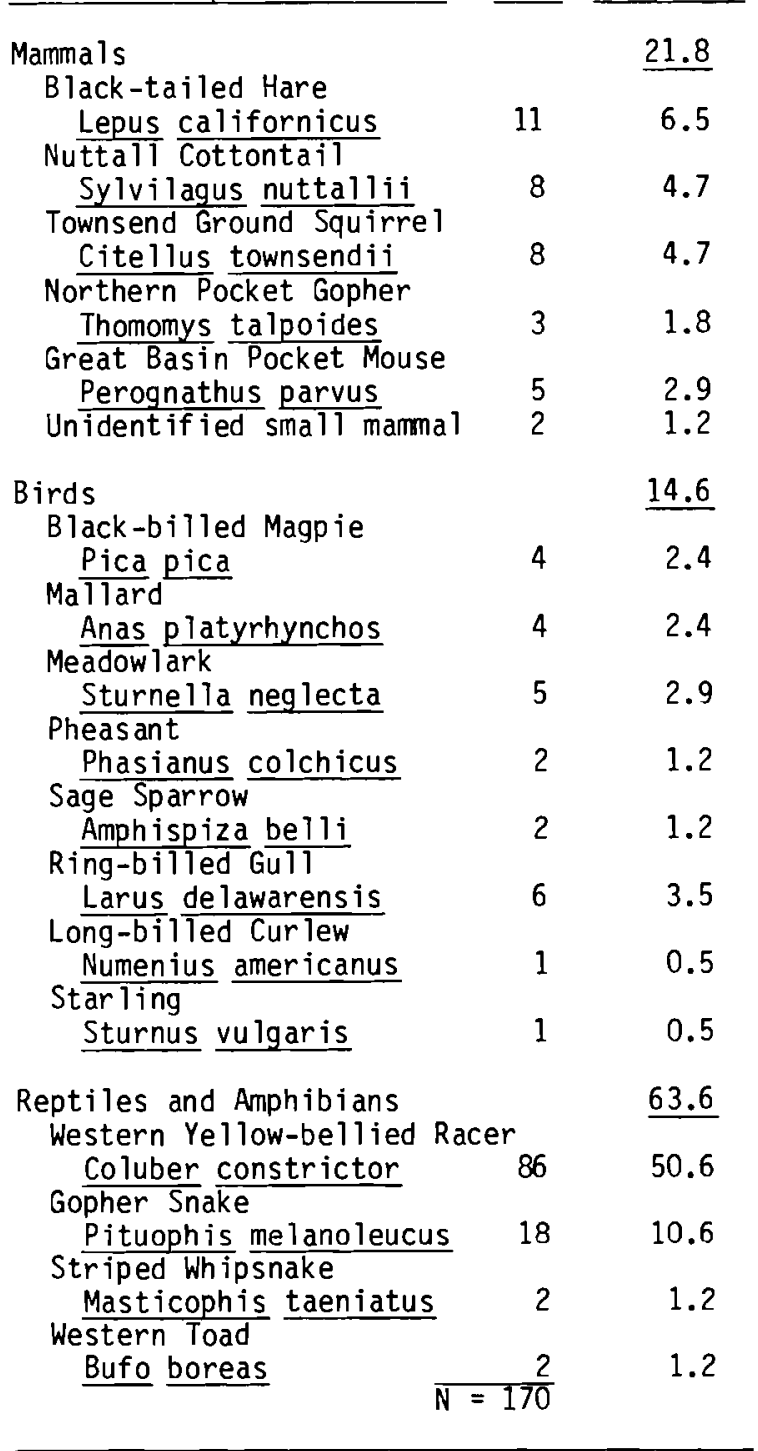

reveal that the Swainson's Hawk is quite adaptable to the change in prey species diversity in the environment and appears to be a generalized hunter. This is certainly a major reason for the fairly wide distributional pattern of the species in North and South America.

During the post-fledging period, young hawks remain strongly dependent on the adults for food. As previously mentioned, the young birds seldom catch vertebrate prey
TABLE 23. Prey Fed to Younq Swa inson's Hawks in Whitman County, Washington near Pullman

$\%$

Prey Species No. Frequency

Mammals

Vole

Microtus spp.

Deer Mouse

Peromyscus maniculatus

Columbian Ground Squirre 1 Citellus columbianus

Northern Pocket Gopher

Thomomys talpoides

Audubon Cot tontail Rabbit Sylvilagus auduboni $i$

Birds

Meadow lark

Sturnella neglecta

Pheas ant

Phasianus colchicus

Gray Partridge

Perdix perdix

Black-billed Magpie

Pica pica

Star ling

Sturnus vulgaris

Reptiles and Amphibians

Common Garter Snake

Thamnophis sirtalis

Insects

Orthoptera

$\underline{79.3}$

96

64.4

5

3.4

8

5.4

8

5.4

1

0.7

$\underline{11.3}$

4.7

7

$3 \quad 2.0$

3

2.0

2

1.3

2

1.3

$\underline{8.7}$

13

8.7

$\frac{1}{149}$

$\frac{0.7}{0.7}$

for themselves but do often forage about on the ground for insects. Analys is of castings from the Hanford Site (Table 26) indicated that insects were more important during the post-fledgling period than during the nestling periods, with snakes, primarily Racers, remaining the most important prey species on a percent frequency basis. Birds dropped in this frequency of occurrence in the hawk's diet during the post-fledgling period, while mammals increased. The shift away from avian prey may reflect the limited hunting capabilities of fledgling hawks but probably is more closely linked to the decreased availability of vulnerable avian prey. The nestling period of the Swainson's Hawk overlaps the nestling and fledgling stage of Meadowlarks and other common steppe birds. These nestling and fledgling birds are susceptible to hawk predation and thus one would expect fewer in the post-fledgling hawk diet. 
TABLE 24. Prey Fed to Young Swainson's Hawks in Franklin County, Juniper Area

$\%$

Prey Species No. Frequency

Mamma ls

Great Basin Pocket Mouse Perognathus parvus

Northern Pocket Gopher Thomomys talpoides

washington Ground Squirre 1 Citellus washingtoni

Deer Mouse Peromyscus maniculatus

Jackrabbits

Lepus spp.

Ord's Kangaroo Rat Dipodomys ordi $i$

Un identified Sma11 Mammal

Birds

Meadow lark

Sturnella neglecta

Reptiles and Amphibians Western Yellow-bellied Racer

Coluber constrictor

Short-Horned Lizard

Phrynosoma douglass $i$

Sagebrush Lizard

Sceloporus graciosus

Insects

Orthoptera

Gryllacrididae

Acrididae

Apote notabilis

Coleoptera

Eleodes sp.

Carabidae

\begin{tabular}{rr} 
& $\underline{26.4}$ \\
8 & 5.8 \\
12 & 8.8 \\
2 & 1.5 \\
2 & 1.5 \\
8 & 5.8 \\
2 & 1.5 \\
2 & 1.5 \\
& 4.4 \\
7 & 4.4 \\
& $\underline{27.8}$ \\
34 & 24.8 \\
2 & 1.5 \\
2 & 1.5 \\
\hline 3 & 41.6 \\
\hline 10 & 1.5 \\
41 & 29.9 \\
138 & 0.7 \\
\hline 2.2 \\
\hline 2
\end{tabular}

TABLE 25. Prey Fed to Young Swainson's Hawks on the Yakima Firing Range Study Area. Prey Species

Number

Mammals

Northern Pocket Gopher

Thomomys talpoides

Great Basin Pocket Mouse

Perognathus parvus

Vo Te

Microtus spp.

Unident if ied mammal

Birds

Meadow lark

Sturnella neg lecta

Black-billed Mago ie

Pica pica

Rept $\overline{i l e s}$ and Amphibians

Western Yellow-bellied Racer

Coluber constrictor

Gopher Snake

Pituophis melanoleucus

Insects

Acrididae

Apote notabilis
1

1

13

2

3

4

6

3

1
TABLE 26. Prey Fed to Young Swainson's Hawks on the Hanford Site During the

Post-fledging Period

$\%$

Prey Species

No. Frequency

Mamma ls

Townsend Ground Squirrel

Citellus townsendi i

Northern Pocket Gopher

$\begin{array}{lll}\text { Thomomys talpoides } & 70 & 11.4\end{array}$

Black-tailed Hare

Lepus californicus $\quad 10 \quad 1.6$

Great Basin Pocket Mouse Perognathus parvus

32.].

Deer Mouse

Peromysus maniculatus

Nuttall Cottontail

Sylvilagus nuttallii

Unidentified small mammal

Birds

Meadowlark

Sturnella neglecta $\quad 7 \quad 1.1$

Ring-billed Gu11

$\begin{array}{lll}\text { Larus delawarensis } & 1 & 0.2\end{array}$

Starling

Sturnus vulgaris

Horned Lark

Eremophila alpestris $\quad 1 \quad 0.2$

Reptipes and Amphibians

Western Yellow-bellied Racer

Coluber constrictor

Gopher Snake

Pituophis melanoleucus $\quad 15 \quad 2.5$

Insects

14.2

Orthoptera

Acrididae

5.1

Apote notabilis

6.2

Co leoptera

Paracatalpa granicola

Polyphylla sp.

Tenebrionidae

Elateridae

Unidentified insects

2.0

0.2

0.2

0.2

0.3

FOOD HABITS OF SWAINSON'S HAWK IN NORTH AMERICA

Papers presenting information on foods eaten by the Swainson's Hawk in North America were searched, resulting in a list of prey items (Table 27). This list represents foods eaten by adult birds during the nesting season. Prey are listed by species in most instances; however, categories for unident ified prey are also included. In reviewing the literature on Swainson's Hawk diets, several papers did not provide actual numbers of individual prey items. In these instances, minimum numbers of each species per collection were calculated and then totaled for inclusion in the table. 
TABLE 27. Prey of North American Swainson's Hawks

\begin{tabular}{|c|c|c|c|}
\hline Comon Name & Lat in Name & $\begin{array}{l}\text { Total per } \\
\text { Species }\end{array}$ & $\begin{array}{l}\text { Total Number } \\
\text { Individuals }\end{array}$ \\
\hline \multicolumn{4}{|l|}{ Niamma ls } \\
\hline Insectivora & & & 1 \\
\hline $\begin{array}{l}\text { Unident if jed Shrew } \\
\text { Carnivora }\end{array}$ & Sorex sp. & 1 & , \\
\hline [nnat dil] Hease 1 & Mustela frenata & 2 & ? \\
\hline Rendent ia -Marmota & & 6 & 6 \\
\hline Rodentid--Ground Squirrels and Prairie Doqs & MarmoLd 5D. & $\mathrm{b}$ & 137 \\
\hline Whitetail Prairie ion & Cynomys gunnison $\mathrm{i}$ & 13 & \\
\hline Uint a Ground Squirerel & Citellus armatus & 16 & \\
\hline Townsend Ground Squirre? & C. townsendii & 13 & \\
\hline Columbian Grouns Squirre? & $\bar{c} \cdot$. columb ianus & $\begin{array}{r}13 \\
9\end{array}$ & \\
\hline Wash ing ton Ground Squirre & & ? & \\
\hline $\begin{array}{l}\text { Thirteen-lined Grnund Squirrel } \\
\text { Richardson Ground Squirrel }\end{array}$ & $\frac{\bar{c}}{\bar{C}} \cdot \frac{\text { Eridencemlineatus }}{\text { richardsoni }}$ & 17 & \\
\hline $\begin{array}{l}\text { Richardson Ground Squirrel } \\
\text { unident if ied around squirrels }\end{array}$ & C. richardsoni & $\begin{array}{r}3 \\
64\end{array}$ & \\
\hline Rodentia--Pocket Gophers & & & 43 \\
\hline Northern Pocket Gopher & Thomonys talpoides & 43 & \\
\hline Rodent ia--Mice and Rats & & & 43 \\
\hline Deer Mouse & Peromyscus so. & 23 & \\
\hline $\begin{array}{l}\text { Ord Kangarno Rat } \\
\text { Great Basin Pocket Mouse }\end{array}$ & Dipadomys ordii & 7 & \\
\hline $\begin{array}{l}\text { Rodent ia--Voles } \\
\text { Reter muse }\end{array}$ & Perognathus parvus & & 114 \\
\hline Unident if ied voles & Microtus spp. & 114 & \\
\hline $\begin{array}{l}\text { Unident if ied Rodents } \\
\text { Lagomorpha }- \text { Hares and Rabb its }\end{array}$ & & & 27 \\
\hline $\begin{array}{l}\text { Lagomorpha- }- \text { Hares and Rabb its } \\
\text { Black tailed Hare }\end{array}$ & Lepus californicus & 75 & 126 \\
\hline unident if ied hares & & 16 & \\
\hline Audubon Cottontail & Sylvilagus audubonii & 3 & \\
\hline Nuttall Cottontail & S. nuttallii & 15 & \\
\hline unident if ied cottontails & & 17 & \\
\hline \multicolumn{4}{|l|}{ Birds } \\
\hline Anser if ormes -- Hater fow 1 & & & 6 \\
\hline Mallard & Anas platyrhynchos & 4 & \\
\hline unident if ied ducks & & 2 & \\
\hline $\begin{array}{l}\text { Galliformes } \\
\text { Ruffed Grouse }\end{array}$ & Bonasa umbellus & 7 & 19 \\
\hline Sage Grouse & Centrocercus uraphasianus & 1 & \\
\hline unident if ied qrouse & Phosianus collobicue & 2 & \\
\hline Gray Partridge & Perdixperdix & 3 & \\
\hline Charadr ifformes--Shorebirds, Gulls, etc. & & & 10 \\
\hline Long-billed Curlew & Numenius americanus & 1 & 10 \\
\hline Killdeer & Charadrius vociferus & 2 & \\
\hline Mounta in Plover & Eupoda montana & 1 & \\
\hline Ring-billed Gull & Larus delawarens is & 6 & \\
\hline Strigiformes--0wls & & & 1 \\
\hline $\begin{array}{l}\text { Burrowing 0w1 } \\
\text { Passer if ormes.-.Perening Birds }\end{array}$ & Speotyto cunicularia & 1 & 105 \\
\hline Horned Lark & Eremophila alpestris & 13 & 105 \\
\hline Black-billed Magdie & Picapica & 6 & \\
\hline Common Crow & Corvus brachyrhynchos & ? & \\
\hline Sage Thrasher & Oreoscoptes montanus & 1 & \\
\hline Loggerhead Shrike & Lanius ludovicianus & 1 & \\
\hline Starling & Sturnus vulgar is & 3 & \\
\hline $\begin{array}{l}\text { Western Meadow lark } \\
\text { Red-winged B lackb ird }\end{array}$ & $\begin{array}{l}\text { Sturnella neglecta } \\
\text { Ageldius phoeniceus }\end{array}$ & $\begin{array}{r}43 \\
1\end{array}$ & \\
\hline $\begin{array}{l}\text { un ident if ied blackbirds } \\
\text { Say's Phoebe }\end{array}$ & Sayornis sava & $?$ & \\
\hline $\begin{array}{l}\text { ay's Phoebe } \\
\text { Lark Bunting }\end{array}$ & $\frac{\text { Sayorn is }}{\text { Calamosp } i \frac{\text { sayd }}{z a} \text { me lanocorys }}$ & $2^{2}$ & \\
\hline $\begin{array}{l}\text { White-crowned Sparrow } \\
\text { Sage Sparrow }\end{array}$ & $\begin{array}{l}\text { Zonotrichia } \\
\text { Amph ispiza be beucophrys } \\
\text { Clii }\end{array}$ & $\frac{1}{2}$ & \\
\hline $\begin{array}{l}\text { Unident if ied lona-spur } \\
\text { Unident if ied Birds }\end{array}$ & Calcarius sp. & 1 & 39 \\
\hline \multirow{2}{*}{\multicolumn{4}{|c|}{ Reptiles }} \\
\hline & & & \\
\hline Snapping Turt le & Che lydra serp & 1 & 1 \\
\hline Lizards & & & 11 \\
\hline $\begin{array}{l}\text { Short-horned Lizard } \\
\text { Fence Lizard }\end{array}$ & $\begin{array}{l}\text { Phrynosoma douglassi } \\
\text { Sceloporus } \\
\text { sp. }\end{array}$ & 2 & \\
\hline unident if jed lizard & & 7 & \\
\hline Snakes & & & 340 \\
\hline Western Yellow-bellied Racer & Coluber constrictor & 259 & \\
\hline Striped whipsnake & Mast icoph is taeniatus & 3 & \\
\hline Gopher Snake & Pituophis me Tanoleucus & 35 & \\
\hline Common Garter Snake & Tharmophis sirtalis & 14 & \\
\hline $\begin{array}{l}\text { Western Hognose Snake } \\
\text { un ident if jed snake }\end{array}$ & Heterodon nasicus & 1 & \\
\hline unidentif ied snake & & 28 & \\
\hline \multirow{2}{*}{\multicolumn{4}{|c|}{ Amphibians }} \\
\hline Sal amanders & & & 5 \\
\hline Tiger Salamander & Ambystoma tigrinum & 5 & \\
\hline Frogs and Toads & & & 11 \\
\hline Unident if jed froq & & 4 & \\
\hline $\begin{array}{l}\text { Western Ioad } \\
\text { unident if ied toad }\end{array}$ & Bufo boreas & $?$ & \\
\hline Fish & & & 5 \\
\hline 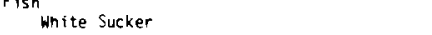 & Cat as tomus commersonnii & 5 & \\
\hline Invertebrates & & & 284 \\
\hline Orthoptera--Grasshopoers and Crickets & & 238 & \\
\hline Neuroptera--Dobsonfifies & & 2 & \\
\hline Coleoptera - Beet les & & 11 & \\
\hline unidentified insects & & 18 & \\
\hline Odonata--Oragonfly & & $\frac{1}{2}$ & \\
\hline Plecoptera- -5 tonef lies & & 2 & \\
\hline Lepidoptera--unident if ied larvae & & 8 & \\
\hline Chiloooda--Cent ipede & & $\frac{1}{2}$ & \\
\hline Arachnida--Spiders & & 3 & \\
\hline Grand Total & & 1336 & \\
\hline
\end{tabular}

Dat d collected from Bendire, 1892: Bent, 1961; Bowles and Decker, 1934; Cameron, 1907, 1913; Coues, 1874; Craighead and Craighead, 1956; Criddle. 1915; Dawson and Bowles, 1909; Dunkle, 1977; Errington and Breck inridoe, 1938; Fisher, 1895; Gabrielson and Jewett, 1970; Jewett et al., 1953; McAtte, 1935; McCreary, 1939; Munro, 1929; 0 lendorff, 1973a; Platt, 1971;
Spton, 1890; Smith and Murphy, 1973; Sutton, 1967; Taverner, 1934; White, 1966; Williams and Matteson, 1948. 
The prey species listed in Table 27 occur mostly in North America and are not available to the Swainson's Hawk on its wintering grounds in South America. Foods eaten by this hawk during the winter are not well known. Hopefully, studies in the future will provide these data.

The prey of the Swainson's Hawk in North America as reported in the literature and from data in this report are $37 \%$ mammals, $13 \%$ birds, $26 \%$ reptiles, $1 \%$ amphibians, $1 \%$ fish, and $21 \%$ insects. The number of species identified include: mammals, 18; birds, 23; reptiles, 8 ; amphibians, 3 ; and fish, 1. Invertebrates were all grouped under the ir respective taxa. The eight most commonly reported prey (and the percentage of total each represents) are as follows: Racer (19\%), grasshoppers and crickets (18\%), Vole (9\%), Black-tailed Hare (6\%), Gopher Snake $(3 \%)$, Meadowlark (3\%), Pocket Gopher (3\%) and Lark Bunting (2\%). These taxa comprised over $60 \%$ of the prey items reported taken by Swainson's Hawks.

The synthesis of prey data for the Swainson's Hawk shows that this raptor is capable of taking a wide variety of prey ranging in size from jackrabbits to grasshoppers. However, the majority of the prey taken probably ranges somewhere between 20 and $200 \mathrm{~g}$. Prey species heavier than $200 \mathrm{~g}$ may be selected less than lighter prey since the capture of these heavier prey may require excessive energy expenditures for the Swainson's Hawk. Also, capture of very small prey would require high energy expenditures since numerous prey organisms would have to be captured in order to produce a meal for the hawk. However, small prey organisms that are expremely abundant seasonally (Orthoptera) can provide an adequate prey base. The size of prey taken would depend on the physical capabilities of the hawk and its energetic requirements. Ideally, a hawk should minimize energy expenditure while at the same time maximizing energy acquisition (food gathering). To accomplish this, the Swainson's Hawk and other raptors must select the most abundant, easily obtainable prey within the size limits dictated by their own size and agility.

0lendorff (1973a) found this type of relationship to exist. He noted that larger raptors took more manmals and fewer birds as prey. This, he stated, was the result of at least two complementary factors. First, the marmal population averaged a greater weight per individual than the bird population, and large raptors selected larger prey. Second, partly as a result of the first point, smaller avian prey species were more vulner$a b l e$ to predation by small raptors. The food of smaller raptors also reflects the pyramid of numbers; smaller prey items are

generally more abundant than larger ones both in species and in numbers of individuals. This generally results in the use of more species as prey by smaller raptors.

This relationship was found in southeastern Washington during this study by examination of the prey taken by Ferrug inous Hawks (Table 28), Red-tailed Hawks (Table 29) and Swainson's Hawks (Table 30). The utilization

TABLE 28. Diet of the Ferruginous Hawk ${ }^{a}$ in Southeastern Washington

Prey Species ${ }^{b}$

Small Mammals

Northern Pocket Gopher Thomomys talpoides

Great Basin Pocket Mouse Perognathus parvus

Washington Ground Squirrel Citellus washingtoni

ord Kangaroo Rat Dipodomys ordi i

Lagomorphs

Black-tailed Hare Lepus californicus

Nuttall Cottontail Sylvilagus nuttallii

Birds

Meadow lark

Sturnella neglecta

Long-billed Curlew Numenius americanus

Black-billed Magpie Pica pica

Horned Lark

Eremophila alpestris

Ring-necked Pheasant Phasianus colchicus

Burrowing 0 w 7

Speotyto cunicularia

Reptiles and Amphibians

Western Yellow-bellied

Racer

Coluber constrictor

Gopher Snake

Pituophis melanoleucus

Insects

(Carabidae, Tenebrionidae, Orthoptera, Elateridae)

Number $\%$ of Individuals Diet

40

5

16

1

16

8

a Weight of pair of Ferruginous hawks, $3200 \mathrm{~g}$ (0lendorff, 1973a).

b From data published by Angell (1969) and Fitzner et al. (1977).

of 14 vertebrate species by the Ferruginous Hawk, 25 by the Red-tailed Hawk, and 26 by 
TABLE 29. Diet of the Red-Tailed Hawka in Southeastern Washington

\begin{tabular}{|c|}
\hline Species $^{b}$ \\
\hline 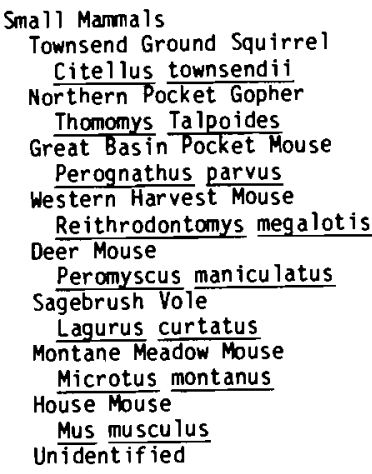 \\
\hline
\end{tabular}

TABLE 30. Diet of the Swainson's Hawk a in Southeastern Washington

Prey Species

Number $\quad \alpha$ of \begin{tabular}{cc}
$\begin{array}{c}\text { Number } \\
\text { Individuals }\end{array}$ & Diet \\
\hline
\end{tabular}

Small Mammals
Great Basin

Great Basin Pocket Mouse

37

Lagomorphs

11

Birds

Meadow lark

Sturnella neglecta

Mourning Dove

Zenaidura macroura

Long-eared ow

Asio otus

Ring-necked Pheasant

Phasianus colchicus

Black-billed Magpie

Pica pica

Columba livia

Chuckar

Alector is graeca

California Quail

Lophortyx californicus 3

Common Flicker

Colaptes auratus

Cliff Swal low

Petrochelidon pyrrhonota 2

Vesper Sparrow

Pooecetes gramineus

Unident if ied

38

Reptiles and Amphibians

Gopher Snake

Pituoph is melanoleucus

western YeTlow-bellied Racer

Coluber constrictor

Prairie Rattlesnake

Crotalus viridis

Garter Snake

Thamnoph is sp.

Insects

Orthoptera

Apote notabilis

Coleoptera

Tenebrionidae

3

awe ight of a pair of Red-tailed hawks, $2252 \mathrm{~g}$

(Craighead and Craighead, 1956).

bFrom data gathered during this study and

data published by Knight and Erickson (1976).
Northern Pocket Gopher

Thomomys talpoides 16

Hashington Ground Squirrel

Citellus washingtoni 2

Peromyscus maniculatus 2

Ord Kangaroo $\frac{\text { maniculatus }}{\text { Rat }}$

Columbian Ground Squirre 1

Columbian Ground Squirre 1
Citel lus columbianus

voles

Microtus spp.

Townsend Ground Squirre 1

Citellus townsendii

109

Black-tailed Hare

Lepus californicus

Hares

Lepus Spp.

Audubon Cottontail

Sylvilagus audubonii

Nuttall Cottontail

Sylvilagus nuttallii

Birds

Black-billed Magpie

Pica pica

Mallard

Anas platyrhynchos

Meadowlark

Sturnella neglecta

Pheasant

Phasianus colchicus

Sage Sparrow

Amphispiza belli

Long-billed Gull

Larus de lawarensis

Ring-billed Curlew
Numenius americanus

Starling

Sturnus vulgaris

Gray Partridge

Perdix perdix

Reptiles and Amphibians

Western Yellow-bellied Racer

Western Yellow-bellied Racer
Coluber constrictor

Pituoph is melanoleucus

St iped Whipsnake

Masticoph is taeniatus

Western Toad

Bufo boreas

Short-horned Lizard

Phrynosoma doug lassi

Sagebrush Lizard

Sceloporus graciosus

Cormon Garter Snake

Thamnophis sirtalis

Insects

Orthoptera

Acrididae

Apote notabilis

GryTlacrididae

Coleoptera

Eleodes Sp.

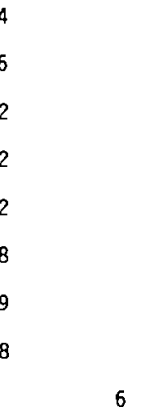

4

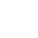

(1)

6

$$
8
$$

11

8

1

8

12

10

4

21

5

2

6

1

3

3

32

120

21

2

2

2

2

13

Tota 1

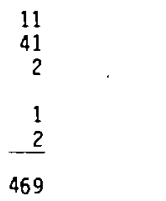

Wheight of a pair of Swainson's hawks, $1755 \mathrm{~g}$. 
the Swainson's Hawk points out that the smaller Swainson's Hawk is more versatile in the selection of prey species than the Ferruginous Hawk, but quite similar to the Red-tailed Hawk.

0lendorff's (1973a) findings that larger raptors took more mammals and fewer birds as prey was not substantiated in this study. I would, therefore, modify his statement by saying that larger raptors do select more large mammals and fewer other vertebrates (birds, reptiles, amphibians, and insects) as prey. This is simply because mammals average a greater weight per individual than other vertebrate prey populations. Lagomorphs, particularly Black-tailed Hares, present in the diets of the three buteos support this case. In examining Tables 28 , 29 , and 30 one readily notices that Ferrug inous Hawks took $12 \%$ hares, while the Red-tailed took $6 \%$ and the Swainson's Hawk $4 \%$. The smaller Cottontail was apparently easier for the Red-tailed to capture, since $9 \%$ of its diet consisted of this prey species. Ferruginous Hawks took only $4 \%$ Cottontails while the smallest Buteo, the Swainson's Hawk, took only $2 \%$.

These three species of Buteos are able to exist side-by-side in western grasslands without directly competing for the same prey resources. The larger Ferruginous Hawk takes less diverse prey than the Red-tailed or the Swa inson's and takes more larger prey (Blacktailed Hares). The Red-tailed and Swainson's take prey in a similar size range but the somewhat smaller Swainson's Hawk preys on a greater diversity of animals.

The hunting strategies of the three buteos may differ enough to reduce competitive interactions. On the Hanford Site for instance, Red-tailed Hawks were often observed hunting in near twilight periods. Swainson's Hawks were seldom observed hunting during the first 2 hours of morning or last hour before sunset. Their hunting activity was noticeably linked to the activity period of the Western Yellow-bellied Racer, the main food item in their diet. This snake became active as the sun warmed the ground's surface in the late morning. A similar pattern of hunting activity existed between

Ferrug inous Hawks and Swainson's Hawks inhabiting the Juniper area, Ferrug inous Hawks being mainly a crepuscular hunter. Whether these differences in hunting strategy existed in the Pullman study area or in other areas of the West where the three Buteos nest is unclear. Future research efforts should be directed toward a study of the behavior of these buteos, particularly in areas where they nest in close proximity to one another.

\section{HUNTING TACTICS}

Numerous observations were made of adult and subadult hunting tactics. Adult Swainson's Hawks hunted primarily by soaring. A bird would typically fly large circles, generally 100 to $300 \mathrm{~m}$ in diameter at a height from 50 to $700 \mathrm{~m}$ above ground. Three hundred $\mathrm{m}$ seemed to be the most frequent elevation assumed during a soaring hunt. On observing a prey organism, the hawk would go into a half-closed wing descent, often approaching very high speeds. On nearing a snake, the hawk generally slowed down by spreading its wings and then slowly landing on the snake. The snake was first seized in the hawk's talons and was then quickly bit either on the head or directly behind the head. In capturina birds or mammals, Swainson's Hawks do not greatly reduce their soaring descent speed just prior to the strike. Instead, they usually hit the prey without landing on it. I could not clearly see exactly how the hit was carried out, but believe that during their diving, Swainson's Hawks used an open hind talon to puncture and tear the prey. Immediately after striking the prey, the hawk would pull up out of the dive and return to the injured prey to deliver several killing bites or punctures.

In another hunting technique the Swainson's Hawks fly in an accipitrine style, generally less than $10 \mathrm{~m}$ above the ground. The hawk flaps for three of four strokes, then glides as it cruises above the ground. Once prey is sighted, the hawk changes its flight pattern to a series of fast, deep, wing beats and then culminates the flight in a rapid plunge to prey on the ground. This hunting tactic was used over areas dominated by shrubs and was highly successful for catching lagomorphs. This technique is similar to that described by Ange 11 (1969) for Ferrug inous Hawks.

Post-fledging hawks were observed using both of the previously described adult hunting techniques, but were only seen capturing prey by using the soaring tactic. The young hawks were also observed capturing insects by chasing them on the ground. They would walk around until spotting an insect, then quickly run after it, catching it either in the ir beaks or in their talons. Young were also observed using a jumping and wingflapping technique to pounce on insects. The young hawks were quite effective in using the ground hunting tactic, particularly on grasshoppers. 
INTRA- AND INTERSPECIFIC RELATIONSHIPS

\section{INTRASPECIFIC RELATIONSHIPS}

Smith and Murphy (1973) used the distances between neighboring hawks as an indication of the degree of tolerance displayed between adjacent pairs of the same species and different species of raptors. On the Hanford Site nesting distances were measured for six pairs of Swainson's Hawks in habitats where nesting sites could have been selected closer together. The mean distance between these nests was $2.35 \mathrm{~km}+\mathrm{S}$.E. 0.34 with a range of 1.5 to $3.2 \mathrm{~km}$. In the Juniper area of southern Frank 1 in County, trees were more homogeneously arranged over the landscape than on the Hanford Site. Nearest neighbor nesting distances for four pairs in the Juniper area ranged from 1.4 to $2.0 \mathrm{~km}$ (mean $1.65+$ S.E. 0.150$)$. This may more closely reflect the tolerance in nesting distances, since trees were uniformly distributed, thus enabling behavioral aspects of nest site selection to play a dominant role in influencing distances between neighbors. Smith and Murphy (1973) noted that nearest neighbor nesting distances in the ir Utah study area averaged $1.88 \mathrm{~km}$ with a range of 1.53 to 2.17. Apparent 1y, Swainson's Hawks se1dom nest closer than $1.5 \mathrm{~km}$.

\section{INTERSPECIFIC RELATIONSHIPS}

\section{Interactions Between Raptor Species}

\section{Hostile Interactions}

Hostile interactions occurred between Swainson's Hawks and Great Horned Owls, Long-eared 0 wls (Asio otus), Marsh Hawks (Circus cyaneus), Red-tailed Hawks, American Kestrels (Falco sparverius), and Golden Eagles (Aquila chrysaetos). Interactions with Great Horned Owls are discussed under the section on post-fledging period mortality.

On two separate occasions at nest site 6 on the Hanford Site, an adult male Swainson's Hawk attacked fledgling Long-eared Owls. (The owl's nest was within $25 \mathrm{~m}$ of the Swainson's Hawk nest). In each attack, the hawk struck flying owls and knocked them to the ground. Neither owl was punctured by the hawk's talons and both recovered from the attack.

At nest site 17 on the Hanford Site, numerous confrontations were observed between Swainson's Hawks and Marsh Hawks. Two pairs of Marsh Hawks nested with in the home range of the Swainson's Hawk. Hostile behavior was generally displayed in the form of pursuit flights. Usually both species ignored one another, but occasionally when a Marsh
Hawk passed near the Swainson's Hawk nest, the male Swainson's Hawk would fly after it. On one occasion, the Swainson's Hawk pursued a female Marsh Hawk, striking her on the back. The Marsh Hawk was apparently uninjured because she flew away with no sign of disability. On several occasions, male Marsh Hawks were observed stooping at perched Swainson's Hawks. Rarely did a Marsh Hawk pursue a flying Swainson's Hawk.

On two separate occasions, one at nest site 1 and the other at nest site 10 on the Hanford Site, I observed territorial displays between Red-tailed and Swainson's Hawks. Each pair of birds soared 'o with in a few meters of one another and did not cross invisible boundary lines. No contact was observed. On another occasion, a pair of Swainson's Hawks at nest site 1 pursued an adult Red-tailed Hawk which had entered their home range. The Swainson's Hawks flew behind and above the Red-tailed hawk and did not try to attack. One of the Swainson's Hawks emitted a call (chirp, chirp, chirp) previously unheard during this study.

Once at nest site 7 on the Hanford Site an immature Golden Eagle was observed displacing two fledgling Swainson's from their nest. The eagle stooped directly at the hawk nest and landed on it. The young hawks flew hurriedly to a nearby tree and were not attacked by the eagle. The eagle sat on the nest for over three minutes, eating a Green Racer the young had been feeding upon. The young had been fighting over the snake immediately before the eagle's visit and this may have increased the eagle's awareness of a potential meal. On leaving the nest, the eagle was pursued by the adult female Swainson's Hawk. The hawk soared above the eagle, stooping at it over 30 times. The eagle was quick to turn over, greeting the fast descending hawk with its talons. Contact was not observed between the birds, but the hawk's agressive stoops seemed to play an important part in driving the eagle out of the area. The eagle eventually soared high above the Swainson's Hawk, disappearing from view.

A pair of American Kestrels nested about $200 \mathrm{~m}$ from a pair of Swainson's Hawks at nest site 17 on the Hanford Site in 1977 . The only interactions observed were persecution flights by the male Kestrel directed at either of the Swainson's Hawks. The small Kestrel would fly above a Swainson's Hawk and then swoop at it as though it were going to collide. At the last moment, the Kestrel would pull up and then hover above the hawk.

The Kestrel seldom displayed this type of hostile behavior, and generally ignored the presence of the Swainson's Hawk. The Swainson's Hawks usually paid no attention to the Kestrels. 
Non-hostile Interactions

Long-eared Owls and Swainson's Hawks were observed nesting in close proximity to one another on three occasions. At nest site 17 on the Hanford Site a pair of Long-eared 0 wls successfully fledged five young from a nest situated in a tree with a nest of Swainson's Hawks. The owls' nest was positioned $6 \mathrm{~m}$ below the hawks. The young owls fledged during June 3-5 while the hawks were still incubating. At nest sites 2 and 6 , also on the Hanford Site, Long-eared Owls nested within $25 \mathrm{~m}$ of active Swainson's Hawk nests. In both instances, owls were successful in fledging young.

A pair of Short-eared Owls (Asio flammeus) nested within $0.8 \mathrm{~km}$ of Swainson's Hawk nest site 17 on the Hanford Site in 1976. No interactions of any sort were observed. Most of the owl activities (courtship and hunting) were restricted to crepuscular times when the hawks were relatively inactive.

Ravens and Swainson's Hawks nested within $75 \mathrm{~m}$ of one another at nest site 1 on the Hanford Site from 1975 through 1977. The ravens were successful in fledging young all three years. No interactions were observed.

\section{Nearest Neighbor Nesting Distances}

The nearest neighbor nesting distances for Red-tailed and Swainson's Hawks were recorded for 10 sets of nests on the Hanford Site. The average nesting distance was $1.66+$ S.E. $0.210 \mathrm{~km}$ with a range of 0.6 to $2.2 \mathrm{~km}$.

Eight sets of Ferruginous and Swainson's Hawks nests in the Juniper area of southern Franklin County indicated that these two species nested from 1.25 to $2.0 \mathrm{~km}$ apart (mean $1.5+$ S.E. 0.090). Smith and Murphy (1973) found the mean nearest neighbor nesting distance for these two species to be $1.27 \mathrm{~km}$ (range 0.47 to $1.71 \mathrm{~km}$ ).

Great Horned Owl and Swainson's Hawk nearest neighbor nesting distances on the Hanford Site ranged from 2.2 to $3.1 \mathrm{~km}$ with a mean of $2.65+$ S.E. $0.187 \mathrm{~km}$. Smith and Murphy (1973) indicated that Swainson's Hawks nested far from Great Horned Owls (mean nesting distance $3.54 \mathrm{~km}$, range 2.98-4.33). Both studies point to a low tolerance levels between these two species.

These interspecies differences in nesting distances may reflect actual tolerance levels which are influenced by each species' activity patterns and habitat requirements (nesting substrate, prey base).

\section{Interactions with Nonraptors}

Long-billed Curlews frequently nested on the same general areas as Swainson's Hawks.
In 1977, a curlew's nest was found within $30 \mathrm{~m}$ of a Swainson's Hawk nest 19 on the Hanford Site. The Swainson's Hawk seldom interacts with curlews and only once have curlews been recorded as prey of these hawks. In 1973, a downy curlew chick (1-3 days old) was found at nest 6 on the Hanford Site. The head and legs of the bird had been eaten, but the remainder of the body was intact. Adult curlews usually do not harass Swainson's Hawks; only twice have I observed curlews pursuing and stooping at adult hawks.

Western Kingbirds (Tyrannus verticalis) often nest in the same tree as Swainson's Hawks (Cameron, 1913; Sharp, 1902). The hawks are attacked by the kingbirds but seem to be little bothered by them. At nest site 17 on the Hanford Site, a pair of kingbirds seemed to have a daily ritual of persecuting the Swainson's Hawks. Usually a kingbird would fly about over a perched hawk, frequently diving in for a quick peck at the hawk's back. Cameron (1913) noted Eastern Kingbirds (Tyrannus tyrannus) actually alighting on a flying hawk's back and being carried around for several seconds. I did not observe this but frequently did note Western Kingbirds flying at and pecking Swainson's Hawks in flight. The kingbirds were always careful to stay above the hawk they were persecuting.

Other bird species I observed nesting in the same tree with Swainson's Hawks were Northern Oriole (Icterus bullockii), Loggerhead Shrike, Starling and Magpie. Sharp (1902) also reported Red-shafted Flickers (Colaptes cafer), Mourning Doves (Zenaidura macroura), House Finches (Carpodacus mexicanus), Northern Orioles and western Kingbirds nesting in the same tree with Swainson's Hawks, while Cameron (1913) noted Western Kingbirds and American Kestrels in the same situation. Griffing (1974) noted Scissor-tailed Flycatchers (Muscivora forficata) nesting in the same tree with Swainson's Hawks. Bowles and Decker (1934) reported the Gray Flycatcher (Empiodonax wrightii), Chipping Sparrow (Spizella passerina) and Lazuli Bunting (Passerina amoena) as species found nesting in low bushes directly below Swainson's Hawk nests.

\section{MANAGEMENT}

\section{MANAGEMENT RECOMMENDATIONS}

Field Evidence for the Potential for Management

0 lendorff and Stoddart (1974) conducted intensive field investigations dealing with the feasibility of managing birds of prey in western grasslands. Olendorff's (1973b) 
investigations on the Hanford Site during the spring of 1973 provided strong evidence that raptor nesting densities were controlled by the availability of nest sites and adequate prey base. In a region of the Hanford Site where trees were absent, he found no nesting by raptors. A second region of the Hanford Site with seven nest sites (groups of trees planted by man) had five being occupied by Swainson's hawks, one by great horned owls and one by common ravens (Corvus corax). 0lendorff and Stoddart (1974) stated that "this total occupancy of Region 2 by raptorial and semi-raptorial species may indicate that prey populations are probably adequate for some raptors, at least, in much of Region 1 , and that the management potential is great in both regions." In a third region of the Hanford Site, nesting densities of large raptors far exceeded those found in Regions 1 and 2. Region 3 was also heavily scattered with trees. Olendorff and Stoddart (1974) thus concluded that the "availability of nest sites apparently had a profound effect on raptor nesting densities up to a point." Figure 35 is a map of the regions 0lendorff (1973b) surveyed on the Hanford Site and with locations of the nests of large birds of prey found during his study.
In surveying the Hanford Site and other regions of southeastern Washington, I found additional evidence to support 0 lendorff and Stoddart's (1974) conclusions. In 1975, seven large tracts of land in southeastern Washington (Fig. 4) were searched for nesting birds of prey. In the Whitman County area the habitat was mostly wheatfields interspersed with small patches of native vegetation (King, 1953; Fitzner and Fitzner, 1975). Trees occurred near homesites along streams and rivers, and also on hillsides where they were planted to retard erosion. Swainson's Hawks and other raptors (Great Horned Owls, Red-tailed Hawks) commonly nested in the area, particularly in those trees farthest from human habitations. The prey resources available in this area were limited mostly to the small patches of uncultivated habitats and hay fields (Fitzner and Fitzner, 1975). These small is lands of vegetation provided a limited prey base (primarily microtines) which was sustaining reproduction of raptors. The presence of adequate nest sites appeared to be the major factor limiting raptor populations.

In the Juniper area, Ferruginous Hawks and Swainson's Hawks were common nesting species. Nesting densities of these two

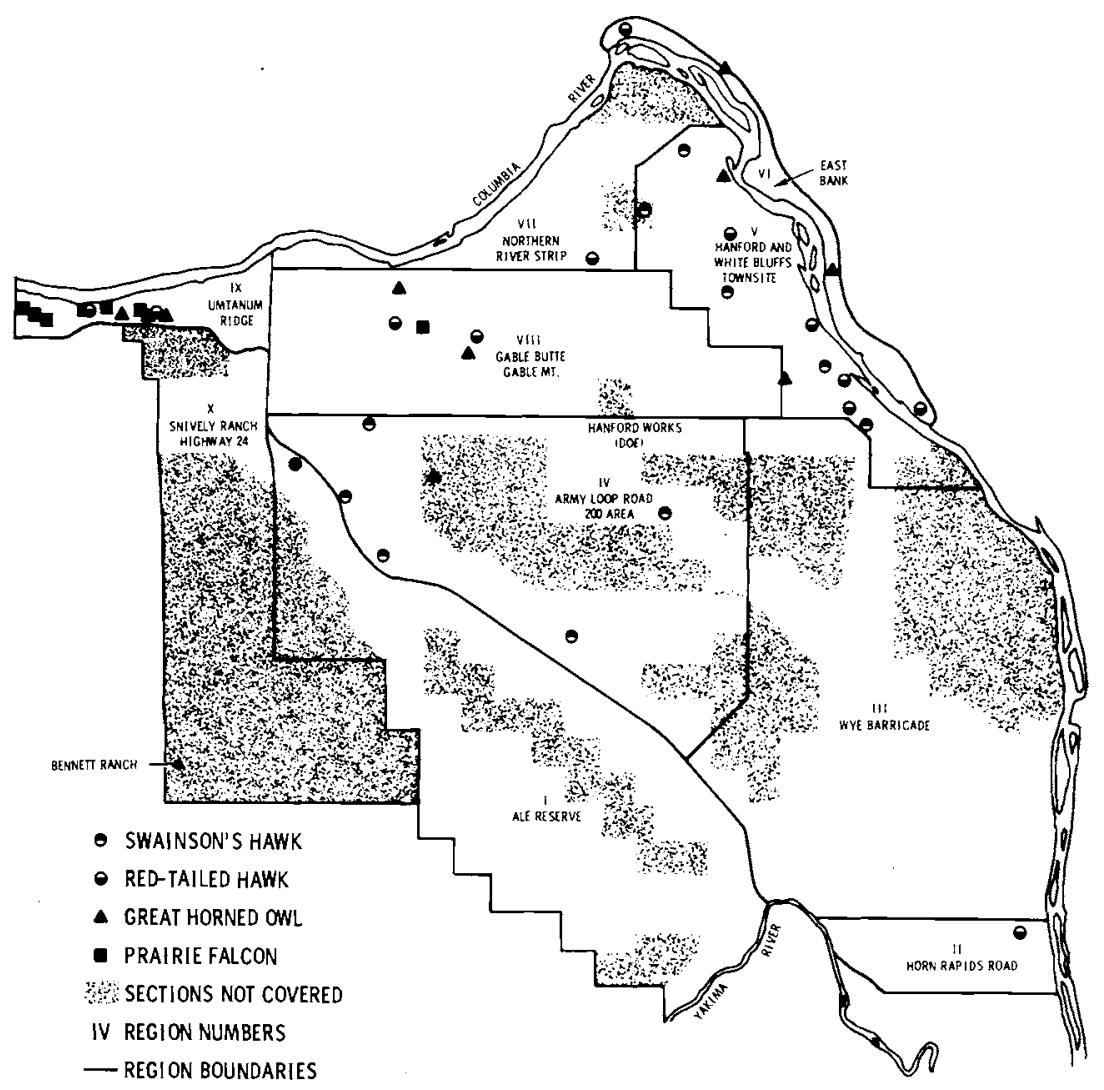

FIGURE 35. Regions surveyed for raptors by 0lendorff in 1972 . 
raptors approached the highest level of all the study areas in the juniper habitat. Fitzner et al. (1977) attributed this to the availability of nest trees, adequate prey base, and lack of human disturbance.

In the Kahlotus/Washtucna area, Swainson's Hawk nesting areas were restricted to a few abandoned homesteads and streamside trees. Basalt cliffs did provide for nesting by Redtailed Hawks, Ferruginous Hawks and Prairie Falcons (Falco mexicanus) and indicated that those species of raptors that were able to nest on other substrates besides trees flourished. The Swainson's Hawks' preference for tree nesting limited its use of an otherwise suitable habitat.

The Grant County area contained seven groups of trees suitable for raptor nesting. Four were inhabited by Swainson's Hawks, two by Common Ravens and one by a Red-tailed Hawk. The total occupancy of all available nest sites by raptors and semi-raptorial species strongly indicated that nest sites were a limiting factor in this area. Only one Swainson's Hawk, no ravens and two Redtailed Hawks fledged from this area in 1975. This is thought to be related to human interference.

The Benton County area encompasses the Horse Heaven Hills plateau and many small farms and orchards in the Yakima Valley. The Horse Heaven Hills plateau contains few trees (only two trees were found that were not associated with active human residences) and cultivated fields. The only native vegetation grows along the ridge top and slopes of the Horse Heaven Hills. The only two trees observed contained active raptor nests. One contained a pair of Swainson's Hawks and the other a pair of Red-tailed Hawks. Trees associated with small farms and orchards provided for nesting by only one pair of Swainson's Hawks, three Redtailed. Hawks and two Great Horned Owls. The high concentration of humans in the farming areas probably strongly influenced the nesting of raptors. The distribution of nesting raptors in the Benton County area may indicate that prey populations on the Horse Heaven Hills plateau can support nesting raptors; however, the lack of nest sites limits the exploitation of otherwise suitable habitat. Human activity in the productive Yakima Valley probably limits nesting by birds of prey in that section of the county, since numerous trees are available for nesting. Prey populations are also believed to be substantial enough to support many nesting pairs of hawks since I have observed large numbers of Red-tailed Hawks, Prairie Falcons, and Rough-legged Hawks hunting in the Valley during fall and winter months.
The Hanford Site studies indicated that raptors nested in the same general area described by 0lendorff (1973b) and that the distribution of nesting raptors is apparently influenced by the availability of nest sites.

On the Yakima Firing Range, trees are restricted to streamsides and springs and nesting by Swainson's Hawks occurs on ly in these areas. In 1975, only one pair of Swainson's Hawks and one pair of Great Horned 0wls were found nesting in the riparian areas. Red-tailed Hawks and Prairie Falcons were also observed nesting on cliffs near the Columbia River. As with the Kahlotus/Washtucna area, those raptors utilizing cliffs for nesting sites were able to exploit habitats where prey were available while tree nesting raptors were not.

The field evidence qathered from the study areas in southeastern Washington, which indicate the potential for raptor management, can be summarized as follows:

- Raptors which are versatile in the type of nesting substrate they select are able to exploit more land areas. Red-tailed Hawks, Ferrug inous Hawks, Great Horned Owls and Ravens nest in trees and on cliffs and hence are able to live in habitats containing these nest substrates. The Swainson's Hawk seldom nests on cliffs but does nest in trees. It, therefore, exploits areas where trees are present. This habit limits the nesting distribution of the species particularly in arid treeless environments.

- Man-created nest sites can strongly influence the abundance and distribution of nesting raptors. Trees planted by man had a profound effect on nesting by Swainson's Hawks on the Hanford Site, the Whitman County area, the Grant County area and the Horse Heaven Hills area. Had man not planted trees in these areas during the early 1900's, those few nesting trees presently available would be absent. Nesting by Swainson's Hawks would be restricted to trees growing along streamsides and springs or to native juniper trees.

- Those areas with limited human access were most successful in fledging young (Table 18) and generally contained high nesting densities. The Hanford Site had limited access and was posted with "No Trespassing" signs, while the Juniper area was simply remote and we 11 hidden from view. These two areas had the highest fledging success of all seven areas examined in 1975, excluding the 
small sample of two nests in the Benton City Horse Heaven Hills area. The other areas were more accessible to humans; particularly the Grant County/Saddle Mountain area. In this area, the fledging success was $0.25 \%$.

- Prey resources were probably being utilized below capacity in most areas. The use of all available nest sites by raptors in the Grant County area, the Horse Heaven Hills area and Regions 1 and 2 on the Hanford Site (0lendorff, 1973b) indicated that these areas were used to full potential for nesting but may further indicate that the areas were not used to capacity for prey resources.

FIELD TECHNIQUE CONSIDERATIONS FOR THE MANAGEMENT OF SWAINSON'S HAWKS

In considering the field evidence for the potential for raptor management, a management plan could be developed that would include the following.

1) Deve lop new nest sites in the Grant County/Sadd le Mountain, Benton County/ Horse Heaven Hills, Whitman County, Kah lotus/Washtucna, and Yakima County areas. The Saddle Mounta in Site, and the Horse Heaven Hills would be the first candidates for this management plan since nest sites are less available in these areas than in the others. Human access could also be controlled in these areas. Nesting structures could include trees or elevated, man-made platforms similar to the one described by 0 lendorff and Stoddart (1974).

\section{Tree Planting}

The disadvantage of planting trees is that it necessitates a water supply to sustain the ir growth until root systems become established. A two-year program for planting and watering small groves of trees, preferably Black Locust (a xeric species), would be enough to give the trees a foothold. Infrequent waterings after the second year (during drought times) may also be necessary. A tank truck, either a fire truck or a fish transporting truck, could serve as a water transporting mechanism. Fifty to a hundred groves of trees could be planted, preferably 50 in the Horse Heaven Hills, and 30 in the Grant County/Saddle Mountain area. Waterings would have to occur weekly during May, June, July and August. The total effort for planting and watering would require about 34 man weeks. Within five to eight years trees should be tall enough to provide nests for raptors. Testing of this management technique would also prove useful to other states interested in maintaining or enhancing raptor populations.

\section{Man-Made Nest Sites}

Olendorff and Stoddart (1974) discussed several types of man-made nest structures which may prove useful in enhancing nesting populations of raptors. In southeastern Washington utility poles and towers could serve as support structures for nesting platforms. Raptors often use the cross arms and other sections of utility poles for nesting (Gilmer and Wiehe, 1977; Olendorff and Stoddart, 1974).

In this study a pair of Swainson's Hawks was also observed nesting in the cross arms of a wooden utility pole. Perhaps by placing artificial nests on everv 10th or 20th pole hawks could be enticed to nest more frequently on utility poles than they presently do. Poles not suitable for nesting could be made so by attaching an artificial nest platform. This plan, however, has one big drawback; utility poles often follow roadways and hawks nesting in them are vulnerable to human disturbance. 0lendorff and Stoddart (1974) indicate that if nests are near roadways, plinkers freely shoot at the nesting hawks from their cars. Nests removed from roadways are less vulnerable to human predation. The placement of artificial elevated platforms in inaccessible areas may therefore merit more effort than placement of artificial nests on accessible utility poles.

2) Close accessible nesting areas, particularly State and Federal Game management lands, during the nesting season. The six accessible nest sites on the Saddle Mountain National Wildlife Refuge and Saddle Mountain State Game Area in Grant County should be posted "No Trespassing" from April 1 through September 1. This should cause little objection from the public, since there are no open game hunting seasons at that time. Off-road vehicle users would probably be the main recreation ists in the area at that time of the year.

Parts of the Juniper area in southern Franklin County should also be posted "No Trespassing" during critical nesting periods. off-road vehicles (ORV) have severely impacted close to one-third of the Juniper area to date and may cause further damage. Surveys in 1977 indicated that in areas of high to moderate ORV use, no nesting occurred by either Ferruq inous or Swainson's Hawks. In nearly identical habitat with no ORV use, both species were common nesters. 0lendorff (1973a) indicates that the Ferruginous Hawk appears sensitive to human activity and that even the slightest disturbances during incubation can cause nest desertion. The Swainson's Hawk (this study) appears less sensitive but is still apt to desert if disturbed early in the nesting season, particularly during nest, egg laying and incubation. 
Since most of the Juniper area is administered by the U.S. Bureau of Land Management (BLM), a large scale comprehensive plan could be developed for managing raptors and other wildlife in the Juniper area. Considering the BLM's fine management of the Birds of Prey Natural Area in Idaho and the passage of the Organic Act, (Public Law 94-579, 94 th Congress) a management plan could and no doubt will be developed. Hopefully, this plan will eliminate ORV use in the Juniper area. In the future, the Juniper area may prove to be a stronghold for nesting raptors. All opportunities presently available to enhance raptor nesting in the area should be adopted.

\section{ENVIRONMENTAL POLLUTANTS}

As top predators in a food chain, raptors can serve as barometers of environmental contamination. Contaminants in prey species have been shown to concentrate hundreds to thousands of times from prey to predator (White, et al., 1973; Hanson and Kornberg, 1956). The environmental contaminants examined in this study are organochlorine pesticides.

\section{ORGANOCHLORINE PESTICIDES}

Chlorinated hydrocarbons, particularly DDT and its derivatives, have been linked to declines in the breeding populations and reproductive success of several bird of prey species. The levels of these chemical compounds in raptors and the ir eggs vary greatiy from one region to another. These variations may be related to real levels in the environment. Interspec if ic variations are no doubt related to differences in food habits and migratory movements. Levels of the pesticide $p, p^{\prime}-D D E$ in eggs of migrant and resident falcons were significantly different in studies of Arctic species by Cade et al. in 1971. For migrant species,
Falco peregrinus, they found that levels in Tundra peregrine eggs averaged 889 ppm DDE lipid basis and in Taiga peregrine eggs levels averaged 673 ppm. For species resident in the same regions, they found that levels in Aleutian peregrine eggs averaged 167 ppm DDE - lipid basis and in gyrfalcon eggs levels averaged $22.5 \mathrm{ppm}$. Since the migrant peregrines winter in regions south of the United States, as far as Argentina, they are predators in some of the most pesticide polluted areas in the Western Hemisphere (Cade et al., 1971).

The Swainson's Hawk also is a long distance migrant, wintering chiefly in Argentina. It too may come in contact with organochlorine pesticides. Peregrine falcons primarily feed on birds while the Swainson's Hawk feeds on small mammals, birds, reptiles, amphibians and insects. These differences in feeding habits affect the degree of pesticide ingestion by each of these raptor species. Cade et al. (1971) noted that raptors that fed mostly upon birds or fish were more highly contaminated with DDE than raptors feeding on herbivorous avian or mammalian prey. The habit of feeding on snakes which have consumed pesticides in the ir prey may place the Swainson's Hawk in greater contact with pesticides than raptors which feed almost exclusively on primary consumers. This study presents data on the concentration of DDE and other organochlorine pesticides in four eggs of Swainson's Hawks collected on the Hanford Site in 1976 (Table 31).

During June of 1976, four infertile Swainson's Hawk eggs were collected from the Hanford Site for analysis of organochlorine residues. The results of the analyses are parts per million (wet weight basis).

DDE, the most common DDT metabolite, ranged from 4.2 to $17.3 \mathrm{ppm}$. Lesser amounts of $p, p^{\prime}-D D D, p, p^{\prime}-D D T$, Heptachlor epoxide, and Dieldrin were also detected.

TABLE 31. Residues of Organochlorine Pesticides, in Swainson's Hawk Eggs from the Hanford Site, Washington. 1976.

\begin{tabular}{|c|c|c|c|c|c|c|}
\hline \multirow[b]{2}{*}{$\begin{array}{l}\text { Nest Site } \\
\text { Location } \\
\end{array}$} & \multirow[b]{2}{*}{$\begin{array}{l}\text { Number } \\
\text { of Eggs } \\
\end{array}$} & \multicolumn{5}{|c|}{ Residue Concentration ppm (Wet Weight) } \\
\hline & & $p, p^{\prime}-D D E$ & $\mathrm{p}, \mathrm{p}^{\prime}-\mathrm{DDD}$ & $\mathrm{p}, \mathrm{p}^{\prime}-\mathrm{DDT}$ & Dieldrin & $\begin{array}{l}\text { Heptachlor } \\
\text { Epoxide }\end{array}$ \\
\hline $\begin{array}{l}1 \\
1 \\
3 \\
6\end{array}$ & $\begin{array}{l}1 \\
1 \\
1 \\
1\end{array}$ & $\begin{array}{r}5.9 \\
7.6 \\
4.2 \\
17.3\end{array}$ & $\begin{array}{l}0.09 \\
0.05 \\
0.07 \\
0.31\end{array}$ & $\begin{array}{l}0.05 \\
0.05 \\
0.09 \\
0.05\end{array}$ & $\begin{array}{l}0.06 \\
0.08 \\
0.33 \\
0.44\end{array}$ & $\begin{array}{l}0.12 \\
0.12 \\
0.10 \\
0.09\end{array}$ \\
\hline
\end{tabular}


The four egg samples came from three dif ferent clutches. Nest site 1 contained four eggs, of which two were infertile. These two infertile eggs contained 5.9 and $7.6 \mathrm{ppm}$ of DDE. The two fertile eggs developed and two young. were fledged. One egg collected from nest site 3 came from a clutch of one. This egg contained $5.9 \mathrm{ppm}$ DDE. Nest site 6 had a clutch of 2 eggs of which one was infertile. The infertile egg contained $17.3 \mathrm{ppm}$ DDE.

In comparing these results with published data for other Buteo species, (Table 32) it becomes apparent that Swainson's Hawks nesting in southeastern Washington contain higher quantities of $p, p^{\prime}-D D E$. Levels of other organochlorine pesticides have not been reported for most Buteos, but Siedensticker and Reynolds (1971) provided data on five
Red-tailed Hawk eqgs while (Henny et al., 1973) provided data for Red-shouldered Hawks which were similar to levels I found in the Swainson's Hawk.

Henny et al. (1973) thought that the levels of Dieldrin in Red-shouldered Hawk eggs $(0.16-2.40 \mathrm{ppm})$ may be sufficient to cause a $9 \%$ decrease in egg shell thickness. Seidensticker and Reynolds (1971) noted a decrease in egg she11 thickness in Redtailed Hawk eggs which may be related to a DDE inhibition of calcium metabolism. Henny et al. (1973) concluded, however, that it was doubtful that the relatively low pesticide levels in the eggs of Red-shouldered Hawks had a detrimental effect on the reproductive performance of the hawk population.

TABLE 32. Residues of Organochlorine Pesticides in Selected North American Buteos

Residue Concentration ppm (Wet Weight) Heptachlor

Location and Year

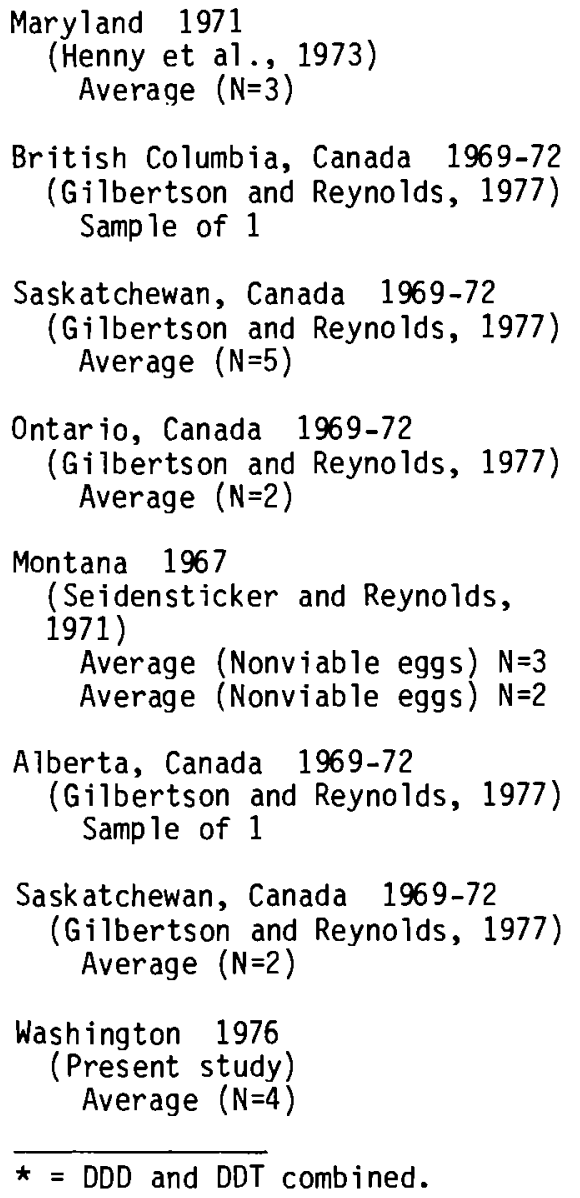


At present it cannot be determined whether or not the levels of pesticides found in the four eggs from the Hanford Site were sufficient to cause egg infertility, but when comparing my data with other published reports it would appear that Swainson's Hawks do contain higher levels of $p, p^{\prime}-D D E$ than other North American Buteos. If one assumed that most raptor species behaved similarly in their physiological response to organochlorine pesticides, then we might conclude that at least one hatching failure from the Hanford Site in 1976 could be attributed to $p, p^{\prime}-D D E$. The egg referred to contained $17.3 \mathrm{ppm} p, p^{\prime}-D D E$, a level that Wiemeyer et al. (1975) stated would cause hatching failure in ospreys. Cade et al. (1971) believed that Peregrine Falcon populations along the Yukon and Colville Rivers in Alaska, where average $p, p^{\prime}-D D E$ levels in eggs are reported as 889 and 673 ppm (1ipid basis) respectively, are beginning to disappear. Their observations on productivity in
1970 indicated that recruitment of young no longer equaled the adult mortality rate and adult pairs had begun to disappear from historic nesting crags. The $p, p^{\prime}-D D E$ level in one egg from the Hanford Site (nest site 6) had $p, p^{\prime}-D D E$ in one egg out of four may indicate that at least some Swainson's Hawks are coming in contact with pesticides and that levels in some eggs may be sufficient to effect populations. Larger sample sizes from wide-ranging areas are needed to fully ascertain the impact of pesticides on

Swainson's Hawks. Hopefully, future studies will concentrate on monitoring organochlorine residues in prey species in both North and South America, in adult birds and their eggs. Only through these studies can we determine where and how organochlorines are being picked up by migratory raptor species. These data are necessary if we are to protect raptor populations from further declines from pesticides. 
Aiken, C. E. H., and E. R. warren. 1914. The biras of El Paso county, Colorado, II, pages 497-bus in Colorado College Publ. Soc. ser., vol. 13 .

Alcorn, G. D. 1y/1. Cneck list - biras of the state of washington, pages 4/4-473 in Uccasional paper No. 4i, Dept. Biology, University of Puget Sound Press, Tacoma, washington.

Amadon, U. 1964. Taxonomic notes on birds of prey. Amer. Mus. Novitates, No. 2166.

American Urnithologists' Union. 1957. Checklist of North American Dirds. Fifth Eaition. Port City Press, Baitimore. 69. pp.

Angel1, T. 1909. A study of the ferruginous hawk: adult and brood behavior, pages 225-241 in The Living Bird (eighth annual). Corneli Laboratory of Ornithology, Ithaca, New York.

Arib, K. 1976. The blue list for 1976. Anierican Birds 29(6):1067-1072.

Arvey, M. U. 1940. A preliminary checklist of the birds of northern Idaho. Unpublished master's thesis, University of Idaho Press, Moscow.

Austing, G. R. 1964. The world of the redtaileu nawk. J. B. Lippincott, Philadelphia and New York. $128 \mathrm{pp}$.

Bailey, H. H. 1931. Swainson's Hawk in Floriaa. Bailey Mus. Nat. Hist. Bull. No. 6 .

baluwin, S. P., H. C. Oberholser and L. G. worley. 1931. Measurements of birds. Scientific Publ. Cleveland Mus. Nat. Hist., Vol. 2, Contribution No. 17. Baldwin Bird Kesearch Laboratory, Gates Mills, Onio. $105 \mathrm{pp}$.

Benaire, C. E. 18y2. Life histories of North American biras. U.S. Nat 1. Mus. Spec. bull. No. 1.

bent, A. C. 1961. Life histories of North American biras of prey, Pt. I. Dover Publ., New York.

blake, K. K. 1977. Manual of neotropical Dirds, Vol. 1. University of Chicago Press, Cnicago. $674 \mathrm{pp}$.
Bond, R. M. 1939. Observations on raptoria) birds in the Lava Beds-Tule Lake region of northern California. Condor 41(2):54-61.

Booth, E. S. 1952. Ecological distribution of the birds of the Blue Mountains region of southeastern Wasnington and northeastern Oregon, pages 65-107 in Walla Walla College Publ. No. 7, Dep. Biōogical Sciences and Biological Sta., Walla Waila College, College Place, Washington.

Bowles, J. H., and F. R. Decker. 1934. Swainson's Hawk in Washington state. Auk $51: 446-450$.

Brown, R. E. 1968. A study of reported faulting in the Pasco Basin. BNWL-662. Battelle, Pacific Northwest Laboratories, Richland, Washington. $47 \mathrm{pp}$.

Brown, L., and D. Amadon. 1968. Eagles, hawks, and falcons of the world. McGrawHil1, New York.

Browning, R. M. 1974. Comments on the winter distribution of the Swainson's hawk (Buteo swainsoni) in North America. Amer. Birds 28(5):865-867.

Bull, J. L. 1958. The changing seasons, a summary of the nesting season. Audubon Field Notes 12(5):416.

Burleigh, T. D. 1972. Birds of Idaho. Caxton Printers, Caldwell, Idaho.

Cade, T. J. 1960. Ecology of the pergrine and gyrfaicon populations in Alaska. University of California Publ. in Zoology 63: 151-267.

Cade, T. J., J. L. Lincer, C. M. White, D. G. Roseneau, L. G. Swartz. 1971. DDE residues and eggshell changes in Alaskan falcons and hawks. Science 172:955-957.

Cameron, E. S. 1907. The birds of Custer and Dawson Counties, Montana. Auk $24: 241-270$.

Cameron, E. S. 1908. Changes of plumage in Buteo swainsoni. Auk 25:468-471.

Cameron, E. S. 1913. Notes on Swainson's hawk (Buteo swainsoni) in Montana. Auk $30: 167-176,387-394$. 
Cline, J. F., D. W. Uresk, and W. H. Rickard. 1977. Plants and soil of a sagebrusn community on the Hanford Reservation. Northwest Science 51:60-70.

Coues, E. 1874. Biras of the Northwest. U.S. Geol. Surv. Terr. Misc. Publ. 3. U.S. Govt. Printing Office, Washington, DC.

Craig, T. H., and C. H. Trost. 1976. The nesting $b i r d s$ of prey the Idaho National Engineering Laboratory Site, pages 38-39 in U. U. Markham, ed. Idaho National Engineering Laboratory Site Ecological Studies Information Meeting. TID-4500, R64. Energy Research and Development Admin., Idaho Operations office, Idaho Falls, Idaho.

Craighead, F. C., and J. J. Craighead. 1950. Hawks, owis, and wildlife. Stockpole Co., Harrisburg, Pennsylvania.

Criddle, N. 1915. Some habits of Swainson's nawk in Manitoba. Ottawa Naturalist 2y: $94-97$.

Curtis, J. T., and R. P. McIntosh. 1950. The interrelations of certain analytical and syntnetic phytosociological characters. Ecology 31:434-455.

Uaubenmire, R. 1970. Steppe vegetation of Washington. Washington Agr. Exp. Sta. Tech. Bul1. 62.

Dawson, W. L., and J. H. Bowles. 1909. The biras of Wasnington. Occidental Publ., Seattle, Washington. $997 \mathrm{pp}$.

Uawson, W. L. 1923. The birds of California, Vol. 3. South Moulton, San Diego, California.

Dickey, D. R., and A. J. Van Rossem. 1938. The Birds of El Salvador. Fjeld Mus. Nat. Hist. Zool. Ser., Vol. 23.

vice, L. K. 1918. The birds of Walla Walla and Columbia Counties, southeastern Washington. Auk $35(1): 40-51$.

Dunk le, S. W. 1977. Swainson's hawks on the Laramie Plains, Wyoming. Auk 94:65-7l.

Dyrness, C. T., J. F. Franklin, C. Maser, S. A. Cook, J. D. Hall and G. Faxon. 1975. Research natural area needs in the Pacific Northwest, USDA Forest Service Gen. Tech. Rpt. PNW-38. USDA Forest Service, Portland, Oregon. $231 \mathrm{pp}$.
Edson, J. M. 1908. Birds of the Bellingham Bay region. Auk 25:425-439.

Errington, P. 0. 1932. Technique of raptor food habits study. Condor 34:75-86.

Errington, P. L., and W. J. Breckinridge. 1938. Food habits of Buteo hawks in northcentral United States. Wilson Bull. 50(2):113-121.

Eyre, L., and D. Paul. 1973. Raptors of Utah. Utah Division of Wildlife Resources, Salt Lake City, Utah.

Farner, D. S. 1954. Birds of Crater Lake National Park. University of Kansas Press, Allen Press, Lawrence, Kansas.

Fenneman, N. M. 1931. Physiography of the western United States. McGraw-Hill, New York.

Fisher, A. K. 1895. Hawks and owls from the standpoint of the farmer. U.S. Dep. Agr., pages 215-232.

Fitch, J. S., F. Swenson and D. F. Tillotson. 1946. Behavior and food habits of the red-tailed hawk. Condor 42:205-237.

Fitzner, R. E. 1975. Color-marked Swainson's hawk. Auk 92(4):885.

Fitzner, R. E., and J. N. Fitzner. 1975. Winter food habits of Short-Eared owls in the Palouse Prairie. Murrelet 56(2):2-4.

Fitzner, R. E. 1977. Time-lapse photography for field studies of raptorial birds, in J. T. Kitchings and N. E. Tarr, eds. Nat 1. Environmental Research Park symposium: natural resource inventory, characterization, and analysis. ORNL-5304, 0ak Ridge National Laboratory, Oak Ridge, Tennessee.

Fitzner, R. E., and J. N. Fitzner. 1977. A hot melt glue technique for attaching radiotransmitter tail packages to raptorial birds. N. Amer. Bird Bander 2(2):56-57.

Fitzner, R. E., D. Berry, L. L. Boyd, and C. A. Rieck. 1977. Nesting of ferruginous hawks (Buteo regalis) in Washington, 1974-75. Condor 79(2):245-249.

Friedmann, H., L. Griscom and R. T. Moore. 1950. Distributional check-list of the birds of Mexico, Pt. I. Pacific Coast Avifauna, No. 29. Cooper Ornothological Club, Berkeley, California. 202 pp. 
Fyfe, R. W., and R. R. Olendorff. 1976. Minimizing the dangers of nesting studies to raptors and other sensitive species. Canaoian wildife Service, Occasional Paper No. 23. $17 \mathrm{pp}$.

Gabrielson, I. N., and S. G. Jewett. 1970. Birds of the Pacific Northwest, Dover Publ., New York.

Gilmer, D. S., and J. M. Wiehe. 1977. ivesting by ferruginous nawks and other raptors on high voltage powerline towers. The Prairie Naturalist 9(1):1-10.

Greene, E. K. 1940. Birds of the lower Florida keys. Florida Acad. Science 8: 200-26b.

Gildertson, M., and L. Reynolds. 1977. A summary of DUE and $P C B$ determinations in Canadian Diras, 1969 to 1972. Canadian wildlife Service. Occasional Paper No. 19.

Griffing, J. P. 1974. Scissor-tailed flycatchers and Swainson's hawks nesting in the same tree. Southwest Nat. 19(1):111-112.

Grinnell, J. 1915. A distributional list of the biros of California. Pacific Coast Avifauna, No. 1i. Cooper Ornithological Club, Hollywood, California. $217 \mathrm{pp}$.

Grinnell, J., and M. W. Wythe. 1927. Directory of the bird-life of the San Francisco bay Region. Pacific Coast Avifauna, No. 18. $160 \mathrm{pp}$.

Griscom, L. 1932. The distribution of Dird-life in Guatemala. Bull. Amer. Mus. Nat. Hist. 64:1-439.

Gullion, G. W., W. M. Pulich and F. G. Evenden. 1959. Notes on the occurrence of biras in southern Nevada. Condor 61(4): $276-297$.

Hanson, W. C., and H. A. Kornderg. 1956. Radioactivity in terrestrial animals near an atomic energy site, in Proc. Int. Conf. Peacefui Uses of Atomic Energy, 13, 385.

Hess, I. E. 1910. One hundred breeding birds of an Illinois ten-mile radius. Auk $27(1): 19-32$.

Henny, C. J., F. C. Schmid, E. M. Martin and L. L. Hood. 1973. Territorial Dehavior, pesticides, and the population ecology of Reo-shouldered nawks in central Maryland, 1943-1971. Ecology 54 (3) 545-554.
Hofslund, P. B. 1973. Do nawks feed during migration, Raptor Research 7(1): 13-14.

Hubbard, J. P. 1974. Flight displays in two American species of Buteo. Condor $76(2): 214-215$.

Hudson, G. E., and C. F. Yocom. 1954. A distributional list of the birds of southeastern Washington. Research studies of the State College of Washington, Vol. 22, No. 1, Pullman, Washington. $56 \mathrm{pp}$.

Ingles, L. G. 1965. Mammals of the pacific states. Stanford University Press, Stanford, California. $506 \mathrm{pp}$.

Jewett, S. G., W. P. Taylor, W. T. Shaw, and J. W. Aldrich. 1953. Birds of Washington state. University of Washington Press, Seattle, Washington. $767 \mathrm{pp}$.

Johnson, S. J. 1973. Reproductive Success and post-fledgling behavior of red-tailed hawks (Buteo jamaicensis) in the Gallatin Valley, Montana. UnpubTished Ph.D. thesis, Montana State University. $61 \mathrm{pp}$.

Johnson, D. R., W. E. Melquist and G. J. Schroeder. 1975. DDT and PCB levels in Lake Coeur d'Alene, Idaho, osprey eggs. Bul1. Environmental Contamination of Toxicology 13(4):401-405.

Johnston, R. F. 1965. A directory to the birds of Kansas. University of Kansas Mus. Nat. Hist. Misc. Publ. No. 41.

Keir, J. R. 1976. Observations of Swainson's hawk nesting in northeastern Illinois. Wilson Bul1. 88(4):658-59.

King, J. R. 1953. Breeding birds of the central Palouse region, southeastern Washington. Unpublished master's thes is, Washington State University, Pullman. 132 pp.

Kitchin, E. A. 1934. Distributional checklist of the birds of the state of Washington. Northwest Faunal Ser. No. 1, Pacific Northwest Bird and Mammal Society. $28 \mathrm{pp}$.

Knight, R. L., and A. W. Erickson. 1976. High incidence of snakes in the diet of nesting red-tailed hawks. Raptor Research $10(4): 108-111$.

Land, H. C. 1970. Birds of Guatemala. Livingston Publ., Wynnewood Pennsylvania. 
Larrison, E. J., and K. G. Sonnenberg. 1968. Washington birds: their location and identification. The Seattle Audubon Society, Seattle, Washington. 258 pp.

Linsdale, J. M. 1936. The biras of Nevada. Pacific Coast Avifauna, No. 23. Cooper Ornithological Club, Berkeley, California. $145 \mathrm{pp}$.

Loetscher, F. W., Jr. 1955. North American migrants in the state of Veracruz, Mexico: A summary. Auk 72:14-54.

Lowery, G. H., Jr. 1960. Louisiana Birds. Louisiana State University Press, Baton Rouge.

Luttich, S. N., L. B. Keith and J. D. Stepnenson. 1971. Population dynamics of the red-tailed hawk (Buteo jamaicensis) at Rochester, Alberta. Auk 88:75-87.

Marsha11, D. B. 1969. Endangered plants and animals of Oregon, Pt. III, Birds. Spec. Rpt. 278. Agr. Exp. Sta., Oregon State University, Corvallis. $23 \mathrm{pp}$.

Mathisen, J. E., and A. Mathisen. 1968. Species abundance of diurnal raptors in the panhandle of Nebraska. Wilson Bul1, 80(4): 479-486.

Matray, P. F. 1974. Broad-winged hawk nesting and ecology. Auk 91:307-324.

Mayer, W. V. 1952. The hair of California manmals with keys to the dorsal guard hairs of California mamnals. Amer. Midland Naturalist 48:480-512.

McAtee, W. L. 1935. Food habits of common hawks, pages $1-36$ in U.S. Dep. Agr. Circ. No. 370 .

Mccreary, 0. 1939. Swainson's hawk in Wyoming. Wyoming Wildlife $4(2,3): 4$.

Meyer De Schauensee, R. 1964. The birds of Columbia. Livingston Publ., Narberth, Pennsylvania. $430 \mathrm{pp}$.

Meyer De Schauensee, R. 1966. The species of birds of South America and their distribution. Livingston Publ., Narberth, Pennsylvania. $577 \mathrm{pp}$.

Monroe, B. L., Jr. 1968. A distributional survey of the birds of Honduras. Ornithological monographs No. 7. The American Ornithologists' Union. Allen Press, Lawrence, Kansas. 458 pp.
Moon, E. L. 1949. Notes on hawk and ow 1 pellet formation and identification. Trans. Kansas Acad. Science 43:458-466.

Munroe, J. A. 1929. Notes on the food habits of certain raptors in British Columbia and Alberta. Condor 31:112-116.

Nice, N. M. 1941. The role of territory in bird life. Amer. Midland Naturalist $26: 441-487$.

Noble, G. K. 1939. The role of dominance in the life of birds. Auk 56:263-273.

Oberholser, H. C. 1974. The bird life of Texas, Vol. 1. University of Texas Press, Austin, pp. 234-236.

Odum, E. P., and E. J. Kuenzler. 1955. Measurement of territory and home range size in birds. Auk $72: 128-137$.

Odum, E. P. 1963. Ecology. Holt, Rinehart and Winston, New York.

Olendorff, R. R. 1971. Falconiform reproduction; a review. Pt. 1, the prenesting period. Raptor Research Rpt. No. 211. $233 \mathrm{pp}$.

0lendorff, R. R. 1973a. Ecology of nesting birds of prey of north-eastern Colorado. U.S. IBP Grassland Biome Tech. Rep. No. 211. Colorado State Univ., Fort Collins, CO.

Olendorff, R. R. 1973b. Raptorial birds of the U.S.A.E.C. Hanford Reservation, southcentral Washington. BNWL-1790. Battelle, Pacific Northwest Laboratories, Richland, Washington. $45 \mathrm{pp}$.

0lendorff, R. R. 1974. A courtship flight of the Swainson's hawk. Condor 76(2):215.

Olendorff, R. R., and J. W. Stoddart, Jr. 1974. The potential for management of raptor populations in western grasslands. In: Management of Raptors, Proceedings of the Conference on Raptor Conservation Techniques, Fort Collins, Colorado, 22-24 March, 1973 (Part 4). F. N. Hamerstrom, Jr., B. E. Harrell and R. R. Olendorff, Editors. Raptor Research Report No. 2, pp. 44-88.

01rog, C. C. 1967. Observaciones sobre aves migratorias del hemisferio norte. Hornero 10:292-298. 
0lson, A. C. 1942. A preliminary annotated checklist of the birds of northern Idaho. Unpublished master's thesis, University of IGano, Mioscow.

Phillips, A., J. Marshal and G. Monson. 1964. The birds of Arizona, University of Arizona Press, Tuscon.

Pilz, W. R. 1976. Possible cannibalism in Swainson's nawk. Auk 93:838.

Platt, J. B. 1971. A survey of nesting hawks, eagles, falcons and owls in Curlew Valley, Utah. Great Basin Naturalist $31(2): 51-68$.

Purque, J. R., C. C. Carpenter and D. L. Marcellini. 1972. Spring migration of swainson's hawk and turkey vulture through Veracruz, Mexico. Wilson Bul1. 84(1):92-93.

Rathbun, S. F. 1902. A list of the land birds of Seattle, Washington, and vicinity. Auk 19:131-141.

kickard, W. H. 1960. The distribution of small mammais in relation to the climax vegetation mosaic in eastern Washington and nortnern Idaho. Ecology 41(1):91-106.

Kickard, W. H., J. U. Hedlund and R. G. schrecknise. 1974. Mammals of the Hanford Reservation in relation to management of radioactive waste. BNWL-1877. Battelle, Pacific Nortnwest Laboratories, Richland, washington. $58 \mathrm{pp}$.

Roboins, C. S., B. Bruun and H. S. Zim. 1966. Birds of North America. Western Publ., Racine, wisconsin. 340 pp.

Saunders, A. A. 1921. A distributional list of the birds of Montana, pages 62-63 in Pacific Coast Avifauna, No. 14. Cooper Ornithological Club, Berkeley, California.

Seton, E. T. 1890. The birds of Manitoba. Proc. U.S. Nat7. Mus. 13:457-643.

Seidensticker, J. C., and H. V. Reynolds. 1971. The nesting, reproductive performance, and chlorinated hydrocarbon residues in the Red-tail hawk and Great Horned owl in south-central Montana. The Wilson Bullet in 83(4):408-418.

Sharp, l. S. 1902. Nesting of Swainson hawk. Condor 4(4):116-118.

Skutch; A. F. 1945. The migration of Swainson's and broad-winged hawks through Costa Rica. Northwest Science 19(4):80-89.
Skutch, A. F. 1969. Notes on the possible migration and nesting of the black vultures in Central America. Auk 86:726-731.

Smith, D. G., and J. R. Murphy. 1973. Breeding ecology of raptors in the eastern Great Basin of Utah. Brigham Young University Science Bull., Biological Ser. $18(3): 1-76$

Smith, D. G., and J. R. Murphy. 1978. Biology of the Ferruginous Hawk in central

Utah. Sociobiology 3(2):79-95.

Snyder, N. F. R. 1974. Breeding biology of swallow-tailed kites in Florida, pages 73-97 in The living bird (thirteenth annual). Cornell Laboratory of Ornithology, Ithaca, New York.

Sprunt, A., Jr. 1954. North American birds of prey. Natl. Audubon Soc. and Harper and Brothers, New York. 227 pp.

Stebbins, R. C. 1954. Amphibians and reptiles of western North America. McGrawHill, New York. 536 pp.

Stewart, R. E., and H. A. Kantrud. 1972. Population estimates of breeding birds in North Dakota. Auk 89:766-788.

Stone, W. A., D. E. Jenne, and J. M Thorp. 1972. Climatography of the Hanford Area. BNWL-1605. Battelle, Pacific Northwest Laboratories, Richland, Washington. 276 pp.

Sutton, G. M., and 0. S. Pettingill, Jr. 1942. Birds of the Gomez Farias region, southwestern Tamaulipas. Auk 59:1-34.

Sutton, G. M. 1967. Oklahoma birds. University of 0klahoma Press, Norman. 674 pp.

Taverner, P. A. 1934. Birds of Canada. Nat1. Mus. of Canada Biological Ser. No. 19, Bul1. No. 72. J. 0. Patenaude, Ottawa. $445 \mathrm{pp}$.

Thorp, J. M., and W. T. Hinds. 1977. Microclimates of the Arid Lands Ecology Reserve, 1968-1975. BNWL-SA-6231.

Battelle, Pacific Northwest Laboratories, Richland, Washington. 100 pp.

U.S. Department of Agriculture. 1941. Climate and man: yearbook of agriculture. $1248 \mathrm{pp}$.

U.S. Department of Interior. 1973. The channeled scablands of eastern Washington. No. 2401-02436. GPO. Washington, DC. 
Weston, J. B. 1969. Nesting ecology of the Ferruginous Hawk. In J. R. Murphy, F. J. Camenzind, D. G. Smith, and J. B. Weston. Nesting ecology of Raptorial Birds in central Utah. Brigham Young Univ. Sci. Bull., Biol. Ser. 10:25-36.

Wetmore, A. 1965. The birds of the Republic of Panama, pages 209-211 in Smithsonian Miscellaneous Collections, VoT. 150, Publ. 4617. Smithsonian Institute, washington, DC.

White, C. M. 1965. Roadside raptor count through Utah, Colorado and Kansas. Kansas Ornithological Society Bul1. 16(3):18-19.

White, C. M. 1966. Notes on the food of the Swainson's hawk. Kansas Ornithological Soc. Bul1. 17:10.

White, C. M., W. B. Emison and F. S. L. 1973. DDE in a resident aleution island pergrine population. Condor 75:306-311.
Wiemeyer, S. N., P. R. Spitzer, W. C. Krantz, T. G. Lamont and E. Cromartie. 1975. Effects of environmental pollutants on Connecticut and Maryland ospreys. Journal of Wildlife Management 39(1):124-139.

Wiley, J. W. 1975. The nesting and reproductive success of red-tailed hawks and redshouldered hawks in Orange County, California, 1973. Condor 77(2):133-139.

Willett, G. 1933. A revised list of the birds of southwestern California. Pacific Coast Avifauna, No. 21. 204 pp.

Williams, R. B., and C. P. Matteson, Jr. 1948. Wyoming hawks. Publ. No. 5. Wyoming Game and Fish Commission, Cheyenne. 1948.

Zarn, M. 1975. Rough-legged hawk (Buteo lagopus sanctijohannis). Habitat management series for unique or endangered species, Rpt. No. 14. U.S. Dep. Interior: Bur. Land Management, Denver, Colorado. 
No. of

Copies

OFFS ITE

A. A. Churm

DOE Chicago Patent Attorney

9800 South Cass Avenue

Argonne, IL 60439

27 DOE Technical Information Center

K. C. Clusen

Department of Energy

Assistant Secretary for Environment

Washington, DC 20545

P. B. Dunaway

DUE Nevada Operations Office

P.O. Box 14100

Las Vegas, NV 89114

0. D. Markham

Radiological and Environmental

Sciences Laboratory

DOE Idaho Operations office

P.0. BOx 2108

Idaho Falls, ID 83401

7 DOE Office of Health and Environment

Research

Washington, DC 20545

N. F. Barr

W. W. Burr

R. C. Dahlman

R. E. Franklin

W. S. Osburn

J. Swinebroad

R. L. Watters

S. Meyers

DOE Office of Nuclear Waste Management Washington, DC 20545

5. I. Auerbach

Oak Ridge National Laboratory

P.U. Box $X$

Oak Ridge, TN 37830

R. H. Baker

The Museum

Michigan State University

East Lansing, MI 48823

I. L. Brisdin, Jr.

Savannah River Ecology Laboratory

Aiken, SC 29801

Office of Nuclear Waste I solation

Att: Beverly Rawles

Battelie Memorial Institute

$505 \mathrm{King}$ Avenue

Columbus, $\mathrm{OH} 43201$
No. of

Copies

T. E. Hakonson

Los Alamos Scientific Laboratory

P.0. Box 1663

Los Alamos, NM 86544

R. L. Knight

Washington Department of Game

600 N. Capitol Way

Olympia, WA 98504

M. Smith, Director

Savannah River Ecology Laboratory

Drawer E

Aiken, SC 29801

F. W. Whicker

Radiology and Radiation

Biology Department

Colorado State University

Fort Collins, CO 80521

\section{ONSITE}

Hanford Engineering Development Laboratory

G. D. Carpenter

10 DOE - Richland Operations

J. C. Cummings

0. J. Elgert/J. L. Rhoades

R. E. Gerton

B. R. Goranson

H. E. Ransom/F. Austin

M. W. Shupe

F. R. Standerfer/P. G. Harris

M. W. Tiernan/D. R. Elle

M. G. White/P. F. Dunigan

M. J. Zamorski

41 Pacific Northwest Laboratory

W. J. Bair

L. L. Cadwe 11

R. E. Fitzner (20)

K. E. Harding (3)

W. T. Hinds

M. C. McShane

D. E. Olesen

W. H. Rickard

N. M. Sherer

W. L. Templeton

B. E. Vaughan

M. L. Warner

W. R. Wiley

Technical Information (5)

Publication Coordination (2) 


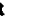

